\title{
4. SITE 384: THE CRETACEOUS/TERTIARY BOUNDARY, APTIAN REEFS, AND THE $J$-ANOMALY RIDGE
}

\author{
The Shipboard Scientific Party
}

\section{SITE DATA}

Position: $40^{\circ} 21.65^{\prime} \mathrm{N}, 51^{\circ} 39.80^{\prime} \mathrm{W}$

Water Depth (PDR, sea level): 3909 meters

Water Depth (PDR, rig floor): 3919 meters

Bottom Felt at (rig floor): 3920 meters

Penetration: 330.3 meters

Number of Holes: 1

Number of Cores: 22

Total Length Cored: 195.3 meters

Total Core Recovered: 110.52 meters

Core Recovery: 57 per cent

Oldest Sediment Cored: Bioclastic limestone Bottoms at: 324.8 meters

Age: late Barremian-early Albian

Velocity: $2.05 \mathrm{~km} / \mathrm{sec}$

Nature of Basement: Vesicular tholeiitic basalt Encountered at: 324.8 meters

Velocity: $3.46-4.32 \mathrm{~km} / \mathrm{sec}$

Date Occupied: $2238 \mathrm{Z}$ hours, 12 July 1975

Date Departed: 0502Z hours, 15 July 1975

Time on Site: 2 days, 6 hours, 24 minutes

Principal Results: A 330.3-meter section was drilled on the $J$-Anomaly Ridge where it emerges above the Sohm Abyssal Plain and lower continental rise south of the Grand Banks. The hole bottomed in altered vesicular basalt which plugged the bit and jammed the core barrel in the drill string. We anticipated that a prominent reflector within the acoustically non-laminated sediments covering the ridge

${ }^{1}$ Brian E. Tucholke (Co-Chief Scientist), Lamont-Doherty Geological Observatory, Palisades, New York; Peter R. Vogt (CoChief Scientist), Naval Research Laboratory, Washington, D.C.; Kenneth R. Demars, University of Rhode Island, Kingston, Rhode Island (now at: University of Delaware, Newark, Delaware); Jon S. Galehouse, San Francisco State University, San Francisco, California; Robert L. Houghton, Woods Hole Oceanographic Institution, Woods Hole, Massachusetts (now at: University of Alberta, Edmonton, Alberta, Canada); Ansis Kaneps, Deep Sea Drilling Project, Scripps Institution of Oceanography, La Jolla, California; John W. Kendrick, Shell Development Company, Houston, Texas; I. N. McCave, University of East Anglia, Norwich, England; Charles L. McNulty, University of Texas, Arlington, Texas; Ivar O. Murdmaa, P. P. Shirshov Institute of Oceanology, Moscow, USSR; Hisatake Okada, Lamont-Doherty Geological Observatory, Palisades, New York (now at: Yamagata University, Yamagata, Japan); and Peter Rothe, Mineralogisch Petrografisches Institut der Universitat Heidelberg, Heidelberg, Federal Republic of Germany (now at: Geographisches Institut der Universitat Mannheim, Mannheim, Federal Republic of Germany). might correlate with "Horizon $A$," which previously had been identified only to the south of the Sohm Abyssal Plain. Reduced drilling rates and recovery of upper lower Eocene chert fragments and silicified limestone at the level of the reflector confirmed this evaluation. The section drilled consists of the following three major lithofacies (top to bottom): (1) marly nannofossil ooze, nannofossil ooze, nannofossil chalk, and foraminiferal nannofossil chalk of middle Eocene to early Maestrichtian age (50 to $193 \mathrm{~m}$ ). This calcareous unit contains excellently preserved foraminifers and nannoplankton in an apparently continuous sequence across the Cretaceous/Tertiary boundary, as well as an excellent assemblage of radiolarians down to the lower Paleocene. Within the limits of resolution imposed by mixing, the boundary is paleontologically sharp. High carbonate content (50 to $100 \%$ ) and moderately uniform sedimentation rates $(\sim 6-10 \mathrm{~m} / \mathrm{m} . \mathrm{y}$. for the Cretaceous and lowermost Paleocene, $\sim 20 \mathrm{~m} / \mathrm{m}$.y. for the upper lower Paleocene, and $\sim 11 \mathrm{~m} / \mathrm{m} . \mathrm{y}$. for the Eocene) indicate deposition in a quiescent environment, probably in intermediate water depths ( 2000 to $3000 \mathrm{~m}$ ), well above the CCD. A hiatus of about 10 m.y. separates the lower Paleocene and lower Eocene oozes. A general uphole decrease in carbonate, slightly accentuated in the upper Maestrichtian to lower Paleocene, probably reflects subsidence of the ridge, and the smaller fluctuations may correlate with variations in the lysocline, variable clay input, or variable surface water productivity. (2) Upper Barremian to Aptian/Albian shallowwater bioclastic (rudist) limestones with minor interbedded calcareous clays ( 200 to $325 \mathrm{~m}$ ), indicating more than 4000 meters of subsidence for this part of the $J$-Anomaly Ridge in the last 105 to $110 \mathrm{~m} . \mathrm{y}$. Subaerial exposure of the bioclastic limestone is indicated by moldic porosity and by $\delta^{18} \mathrm{O}$ values diminished with respect to the overlying oozes, both features being a result of percolation of meteoric waters. Petrographic studies and analysis of the fauna, together with the morphology of the limestone surface as indicated by seismic profiles across Site 384 , suggest that the bioclastic limestone represents a black-reef facies. These limestones appear to be separated from minor overlying Coniacian/Santonian nannofossil ooze by a $\sim 20 \mathrm{~m}$.y. hiatus; another hiatus or very slow accumulation probably occurs between these oozes and the lower Maestrichtian chalks. (3) The bioclastic limestones are underlain below 325 meters by highly vesicular, weathered basalt, apparently formed as subaerial or shallow-water flows. The shallow water or subaerial emplacement of the basalt is supported by deuteric high-temperature oxidation experienced by the opaque minerals. The late Barremian/early Aptian age of the overlying sediment indicates that anomaly $M-2$ is at least $112-118 \mathrm{~m} . \mathrm{y}$. old. Of 5.5 meters of basement penetration, a total of 2.35 meters basalt was recovered, representing portions of three flows. A whole-rock radiometric age of $104 \pm 6 \mathrm{~m} . \mathrm{y}$. is a minimum value. The basalt is a typical mid-oceanic ridge tholeiite and exhibits no iron- 
titanium enrichment or anomalously high NRM which could explain the high-amplitude magnetic $J$-anomaly. However, in terms of light rare-earth enrichment, the basalts at Site 384 are transitional between strongly enriched Icelandic or Azores "plume" basalts and the typically depleted mid-ocean ridge basalts. (La/Sm) $)_{\mathrm{E} . \mathrm{F} \text {. }}$ as well as $\mathrm{TiO}_{2}, \mathrm{P}_{2} \mathrm{O}_{5}$, and La concentrations resemble those measured on the topographically similar Reykjanes Ridge 0 to $250 \mathrm{~km}$ southwest from Iceland.

\section{BACKGROUND AND OBJECTIVES}

The background and objectives at Site 384 are essentially the same as those for Site 383 , and will not be repeated here. Owing to unstable hole conditions, it was not possible to penetrate the turbidite sequence at Site 383.

About $100 \mathrm{~km}$ northeast of Site 383, however, the $J$-Anomaly Ridge emerges above the Sohm Abyssal Plain and Grand Banks continental rise (Figures 1,2). Previous Lynch and Vema data showed that the emergent portion of the ridge is in many ways similar to its deeper extension to the southwest: (1) it has a highamplitude magnetic anomaly and a steep, west-facing escarpment; (2) the acoustic basement is locally quite flat; and (3) a reasonably thick acoustically nonlaminated sediment cover, stratigraphically lower than the turbidite section on the abyssal plain, contains one or more prominent reflectors, the strongest of which was presumed to be Horizon $A^{c}$ (see Tucholke, this volume).

Because we were unable to reach basement and examine the pre-Quaternary sedimentary history at Site 383, we decided to drill on the emergent part of the $J$-Anomaly Ridge at Site 384. Advantages of drilling a shallower part of the $J$-Anomaly Ridge included absence of turbidites, shorter round-trip time, and the likelihood of a better-preserved carbonate sequence on this elevated feature. The primary disadvantage was the possibility that the first sediment accumulation on the crest of the ridge might significantly post-date formation of the crust, leading to paleontologic determination of anomalously young ages for the $J$-Anomaly crust. However, this possibility always accompanies drilling on local topographic highs, including Site 383.

\section{OPERATIONS}

Deterred from our objectives at Site 383 first by tropical storm Amy and later by the sands of the Sohm Abyssal Plain, we decided to drill Site 384 on the $J$-Anomaly Ridge where it emerges above the Grand Banks continental rise (Figures 1, 2).

Site 384 was chosen on the basis of Vema 2801 and Lynch 71 seismic reflection profiles across the $J$-Anomaly Ridge (Figures 3,4). These records show an acoustically non-laminated interval of highly variable thickness ( 0 to $1.2 \mathrm{sec}$; $0.6 \mathrm{sec}$ average) overlying a strong but moderately diffuse basement reflector. On the Lynch profiles the acoustic basement is locally rather flat. Elsewhere the acoustic basement is irregular, and at least in these places it most likely corresponds to basaltic crust. Within the non-laminated layer are one

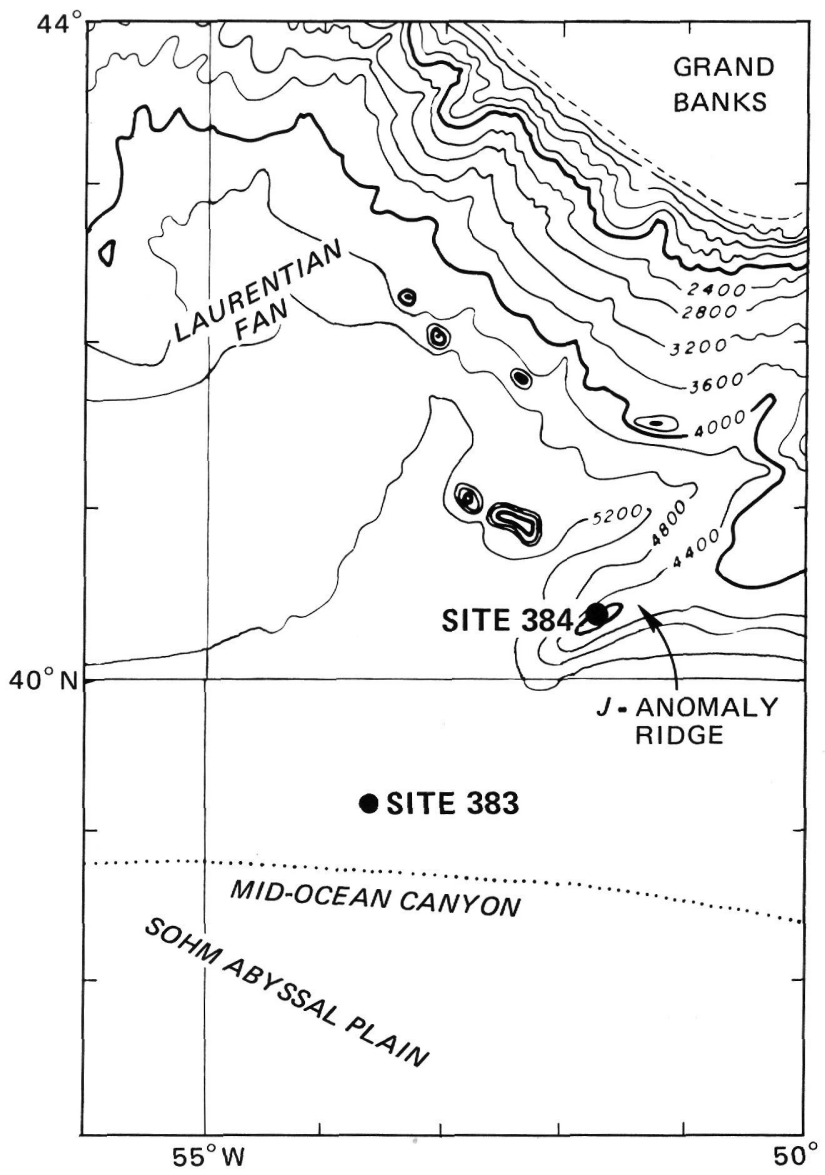

Figure 1. Bathymetric map showing the location of Site 384 on the J-Anomaly Ridge. Depths in meters.

or more prominent reflectors which occur near the base of the layer, within 0.1 to $0.3 \mathrm{sec}$ of acoustic basement. Locally, the deeper reflectors approach the sea floor and may crop out. Site 384 was chosen near the crest of the $J$-Anomaly Ridge, where sediment was thick enought to spud in, but not so thick as to require excessive time for drilling and coring. We also chose a location where the most prominent reflector could be detected within the sedimentary layer.

Our plan was to intercept the Vema 2801 track just east of the crest of the $J$-Anomaly Ridge. In that area the sediment thickness is about $0.4 \mathrm{sec}$, with one prominent reflector midway in the section. Unfortunately, the Challenger seismic reflection record was only of marginal quality (Figure 5), and we consequently had difficulty identifying the mid-sediment reflector.

Two promising sites were observed in the Challenger record, but in each case when we reversed course to return to the site, the ship apparently had been set by currents and the profiler records showed no acceptable drilling locations. At $1911 \mathrm{hr}(2211 \mathrm{Z})$ on 12 July we turned south to cross the $J$-Anomaly Ridge and its gentle southeast-facing flank where a thicker sediment section should clearly exhibit the mid-sediment reflector. Just north of the ridge crest, both "basement" and mid- 


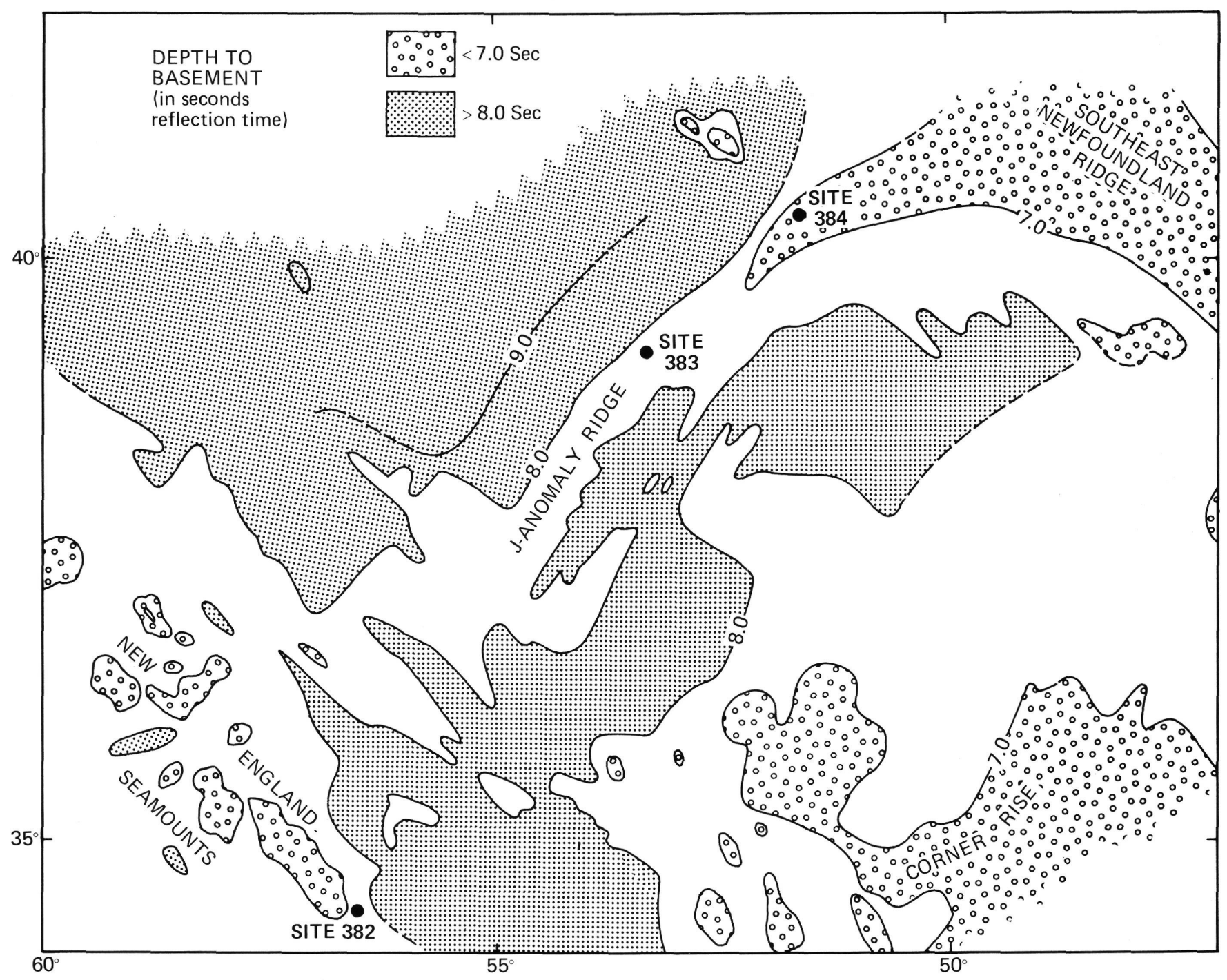

Figure 2. Depth to acoustic basement (in seconds reflection time below sea level) in the vicinity of the J-Anomaly Ridge.

section reflectors became plainly visible, near 0.4 and $0.2 \mathrm{sec}$ sub-bottom, respectively. A beacon was released at $1937 \mathrm{hr}(2227 \mathrm{Z})$, and geophysical measurements were suspended at $1940 \mathrm{hr}$.

An average of 15 satellite fixes at Site 384 established a position of $40^{\circ} 21.65^{\prime} \mathrm{N}, 51^{\circ} 39.80^{\prime} \mathrm{W}$. PDR water depth determined at the time the beacon was dropped was 2075 uncorrected $\mathrm{fm}$; however, the on-site reading was 2086 uncorrected $\mathrm{fm}$. The difference between these values is probably due to horizontal drift of the beacon during its descent through rapid currents at the site. Experience at Site 383 suggested that Matthews' area boundaries might have shifted temporarily south of their chart positions. Values of 3923 meters (Area 9), 3912 meters (Area 8), and 3909 meters (Area 7) were computed for the site and the shallowest of these given to the driller. The actual sea-floor depth, determined by drill-pipe measurement, was 3910 meters, appropriate to Area 7. Because the drill string was being bent by strong current drag, actual depth must be less than this amount; a rough calculation shows this "curvature error" is about 5 to 10 meters.
The drill string was run down, and drilling commenced on the morning of 13 July (Table 1). Our plan was to spot-core the upper 50 to 100 meters of the section, which we anticipated would be current-molded Neogene sediment that was capped by ice-rafted debris from icebergs drifting in the Labrador Current. The first core was brought aboard at $0654 \mathrm{hr}$ from a sub-bottom depth of 50.8 to 60.45 meters. It contained middle Eocene nannofossil ooze with assorted manganese nodules and gravel-size fragments which probably caved into the hole from shallower levels. The gravel presumably was ice-rafted.

The presence of middle Eocene sediments at only 50 meters sub-bottom was surprising and an offset hole was planned, upon completion of Site 384 , to sample the top 50 meters of the section. The offset hole, overtaken by later events, was not drilled.

Because of the rich Eocene fossil assemblage, we began coring continuously below 50 meters. A hard-drilling layer in Core 5 (see Figure 7) was found to be siliceous limestone and chert, and substantiating the mid-sediment reflector as Horizon $A^{C}$. Below a 10 m.y. hiatus at this level, 


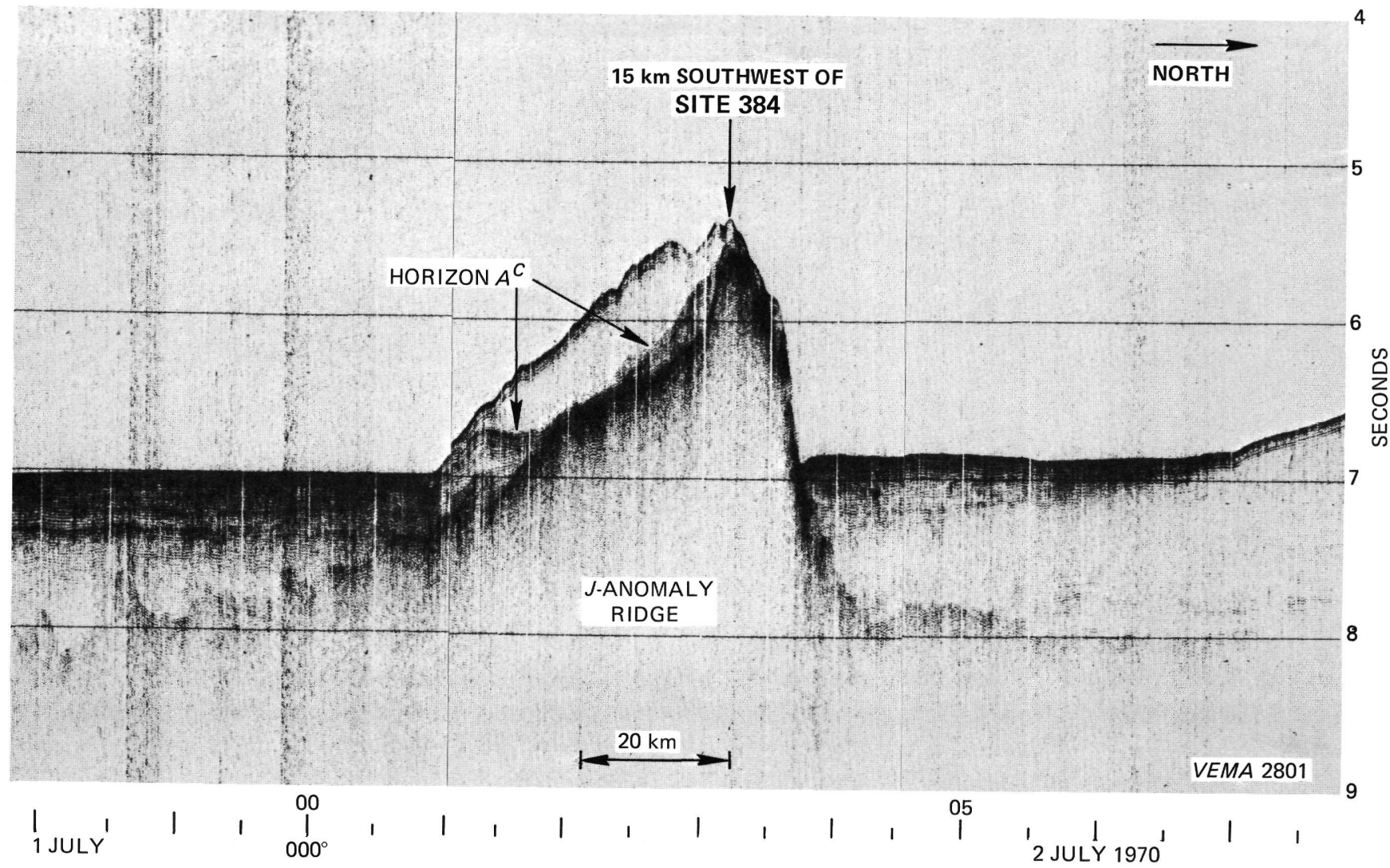

Figure 3. Vema 2801 seismic profiler record across the J-Anomaly Ridge near Site 384. Location of profile shown in Figure 4.

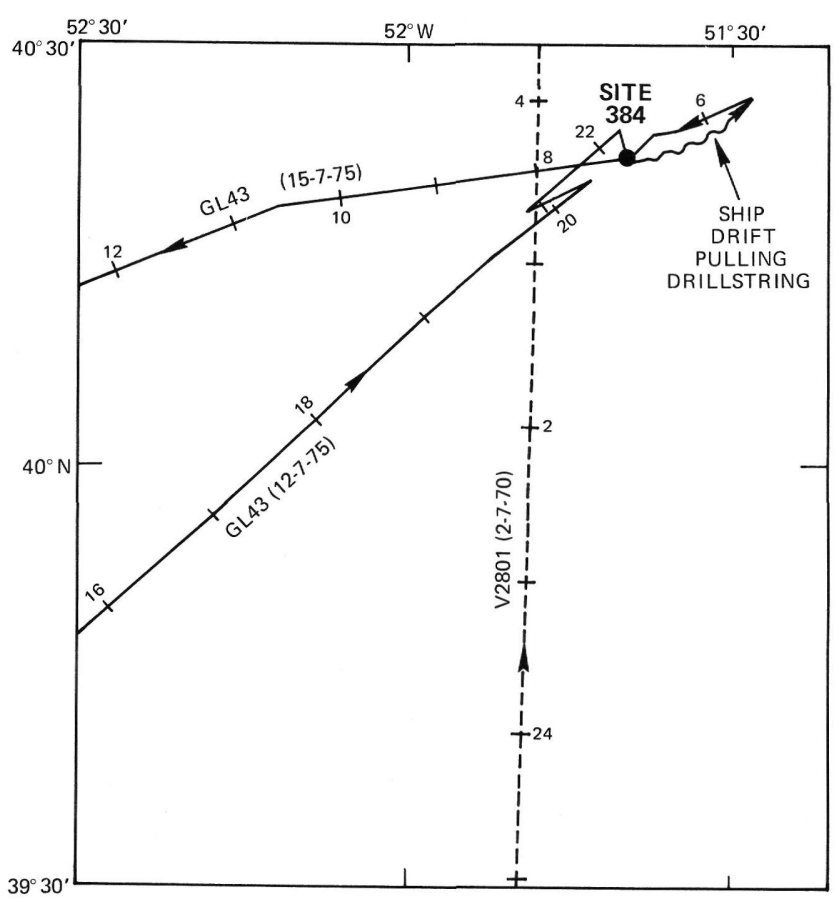

Figure 4. Tracks of Glomar Challenger and Vema 2801 reference profile at Site 384. Dates and hour ticks are shown (Challenger times in GMT).

nannofossil ooze was cored in a continuous biostratigraphic succession down to the lower Maestrichtian
(Core 15, 183.2-192.7 m). Core 13 (164.6-173.6 m), with a seemingly continuous record across the Cretaceous/Tertiary boundary in Section 3, arrived on board at $2159 \mathrm{hr}$ on 13 July. Core recovery in the 15 successive nannofossil-ooze cores in the EoceneMaestrichtian section was relatively high, averaging 75 per cent. Recovery varied randomly from core to core without trend or correlation with lithology.

Remolded shear strength measurements also showed no systematic trend from one core to the next; the principal effect was an increase in shear strength with depth in each core (see Physical Properties). This result implies that a calcareous ooze section such as that at Site 384 might be cored with less drilling disturbance if only a fraction of a joint is cored each time.

Although the weather was calm when we arrived at Site 384 , a northwest wind began to rise and had reached $20 \mathrm{mph}$ by the evening of 13 July. This was combined with a 1.5 to 2 knot current (the Gulf Stream) that strained the positioning system to its limit and threatened the need to abandon the site if conditions worsened.

Having cored continuously into lower Maestrichtian oozes, and because of the marginal weather and current conditions, we began discontinuous coring. At $0118 \mathrm{hr}$ on $14 \mathrm{July}$, Core $16(202.2-211.4 \mathrm{~m})$ recovered Lower Cretaceous shallow-water bioclastic limestone, coarse calcareous sand, and clay. The following three continuous cores returned empty or recovered only a few 


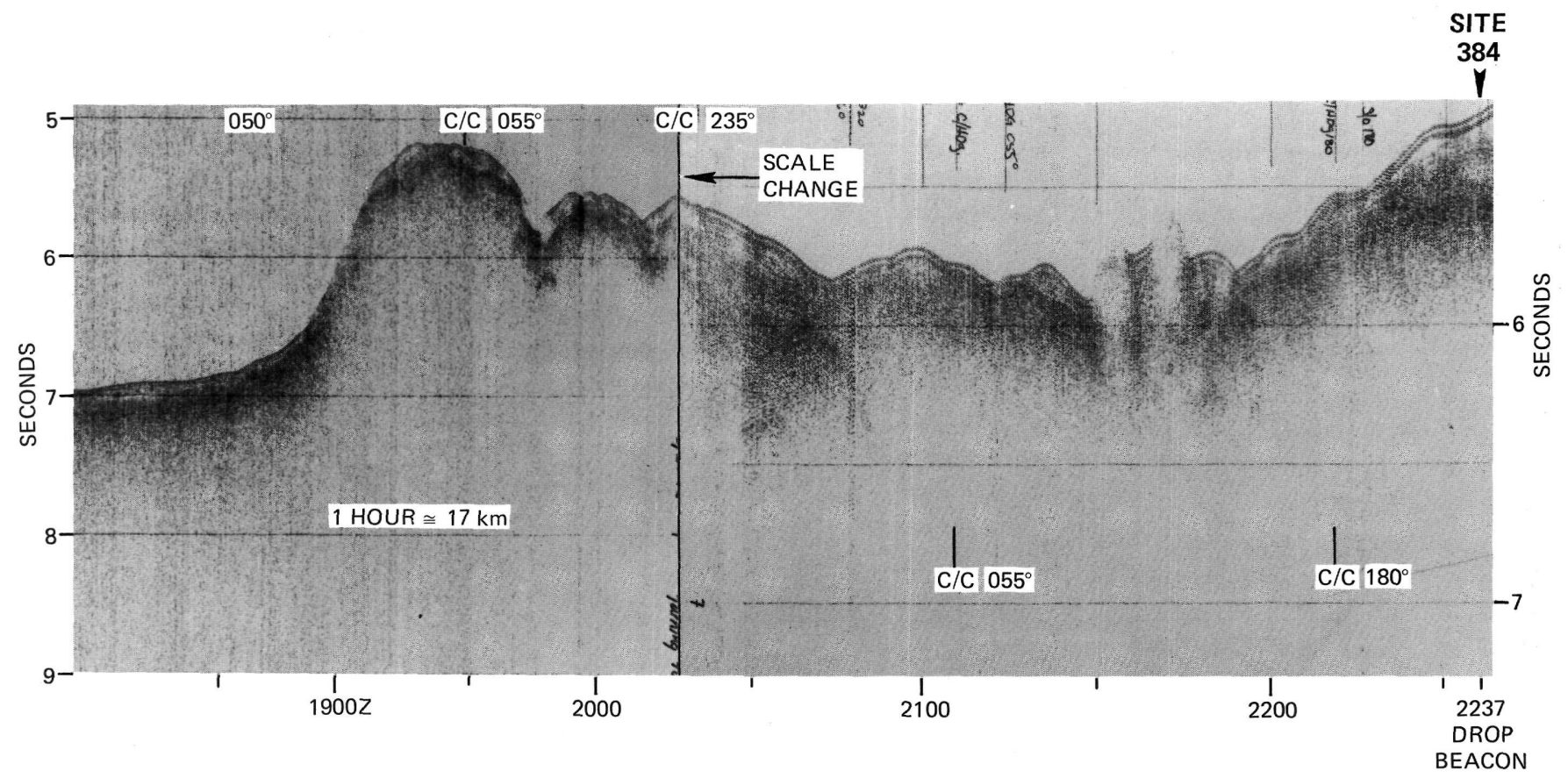

Figure 5. Glomar Challenger profiler record approaching Site 384 (see Figure 15 for interpretation). Location of profile shown in Figure 4.

TABLE 1

Coring and Drilling Summary, Site 384

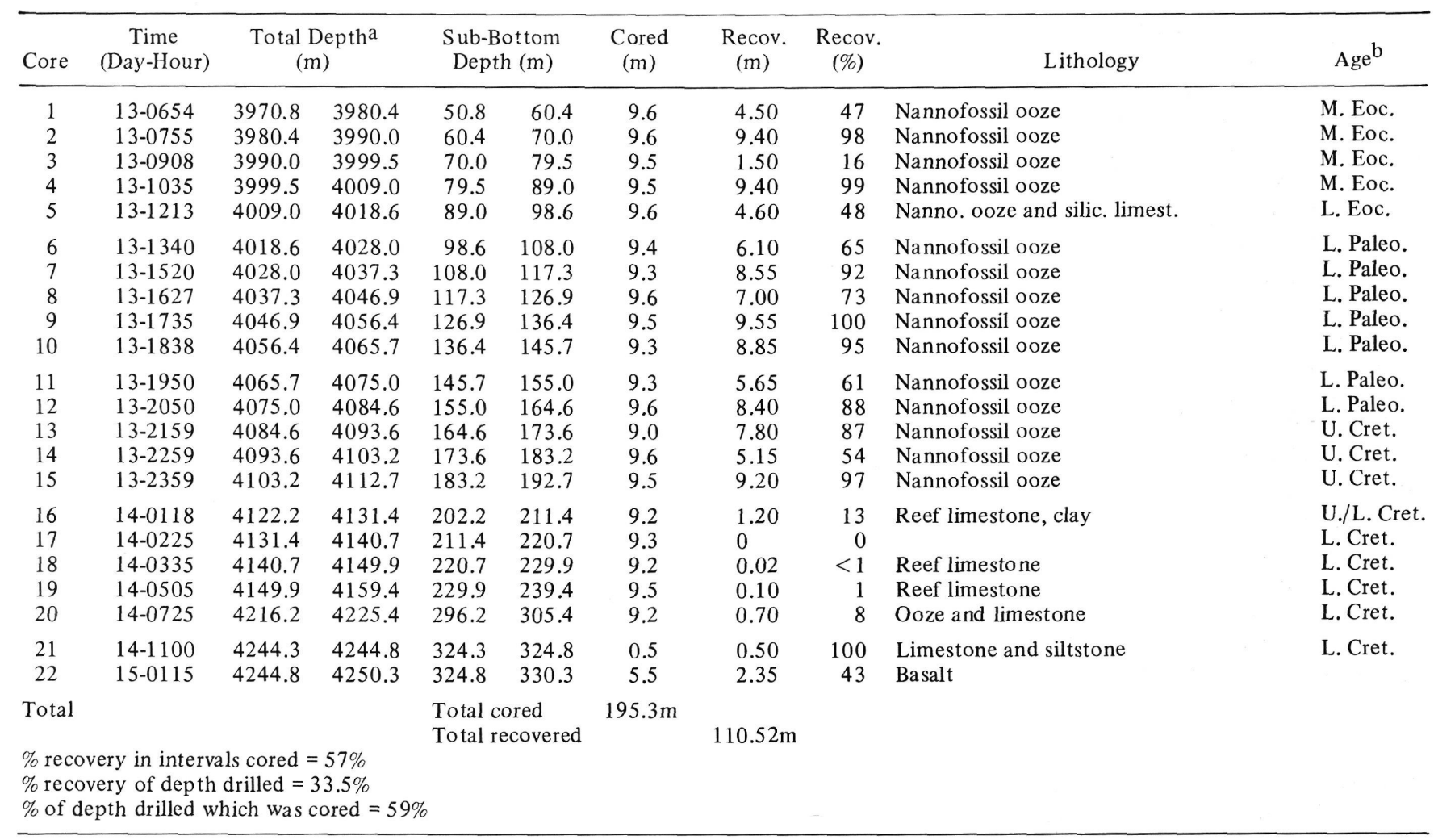

${ }_{\mathrm{b}}^{\mathrm{a}}$ From rig floor, 10 meters above sea level.

${ }^{\mathrm{b}} \mathrm{U}=$ Upper, $\mathrm{L}=$ Lower. 
small limestone fragments. This was apparently a very loose, cobbly, or vuggy limestone which was easily fractured and washed out of the core barrel, even with a plastic sock in the core catcher. We decided to drill 57 meters ahead toward basement and recovered 0.7 meters of ooze and limestone at 296.2-305.4 meters sub-bottom in Core 20. Beginning near the top of the next cored interval (324.3-324.8 m), hard drilling was encountered, and only 0.5 meters penetration was achieved after 60 minutes of drilling (see Figure 7). Meanwhile the drill string had begun to vibrate at a frequency of a few cps and was wearing against the horn because of strong subsurface currents. This, together with winds at $35 \mathrm{mph}$ and gusts to $40 \mathrm{mph}$, as well as a $400-\mathrm{ft}$ excursion at $0930 \mathrm{hr}$, led to a decision to begin pulling out of the hole to avoid possible loss of the drill string. When the drill bit was halfway up, just clear of the sandy limestone unit encountered about 190 meters sub-bottom, the overshot was sent down to retrieve Core 21, which was brought on board at 1100 hours. The core catcher contained a siltstone with abundant volcanic ateration products which suggested close proximity to basaltic crust. With fulfillment of one of the major site objectives apparently so close, we decided to attempt one further core, and the bit was started down once more after the hole had been flushed with mud to expel caving bioclastic detritus. The wind fortunately subsided to 25 to $30 \mathrm{mph}$ after about $1400 \mathrm{hr}$, and the modest swell we were receiving led us to believe the wind was a local advection effect near the northern edge of the Gulf Stream; our satellite weather map showed the ship centered in the middle of a large high-pressure cell. Hard drilling was immediately encountered in Core 22, and after 5.5 meter penetration in 153 minutes, it appeared that the bit was plugged, so it was decided to attempt retrieving the core. The core barrel was jammed tight and it sheared the pin in the overshot; a similar result was obtained in a retrieval attempt after the drill string had been pulled up to the mud line. The core thus had to be retrieved with the drill string, and the roundtrip time necessary to drill an offset-hole precluded our coring the top 50 meters of the sediment section and recoring the Cretaceous/Tertiary boundary.

The drill bit came on board at $0115 \mathrm{hr} 15 \mathrm{July}$, plugged tight with 2.35 meters of weathered basalt. The inner core barrel had been jammed upward, preventing unlatching.

At $0202 \mathrm{hr}$ we were underway on $090^{\circ}$ at 125 turns before turning west to profile across Site 384 (Figures 4, 6). Although we located the beacon upon recrossing the site, the signal was erratic, and we apparently missed the site location by about $0.3 \mathrm{~km}$.

\section{LITHOLOGY}

\section{Introduction}

Although the primary objective at Site 384 on the $J$-Anomaly Ridge was to obtain and date samples of basement associated with the high-amplitude magnetic anomaly, the sedimentary section provided an apparently continuous section of fossiliferous calcareous ooze spanning the Cretaceous/Tertiary boundary, as well as a suite of shallow-water limestones from a reef complex overlying the basement (Figure 7).

The lithologic sequence in this borehole is divided into three lithologic units (Table 2). The sea floor at Site 384 probably is covered with abundant manganese nodules and glacial erratics because these were found as downhole contamination in the majority of the oozes and chalks in Cores 1 to 15 . The upper 50 meters of the section were not sampled, but they probably contain sediment similar to lithologic Unit 1 which is nannofossil ooze and chalk more than 150 meters thick. Piper (1975) recovered foraminifer nannofossil ooze and icerafted debris in dredge samples taken 8 miles east of Site 384 , and a piston core contained 10 meters of foraminifer nannofossil and nannofossil ooze with varying amounts of terrigenous sediment extending down to upper Pliocene. Unit 1 is divided into three sub-units (Tables 2 and 3). Sub-unit 1A is marly nannofossil ooze of Eocene age with a lower boundary at cherty limestones and chert of Horizon $A^{c}$; Sub-unit 1B is nannofossil ooze and chalk bounded by a faint but distinct color change and burrow mottling change at the Cretaceous/Tertiary boundary; and Sub-unit 1C comprises Upper Cretaceous nannofossil chalk above the shallow-water limestones. Lithologic Unit 2 is shallowwater bioclastic limestone, mainly biomicrites and biomicrudites, overlying basalts (Unit 3). Compositional data, based on smear-slide analyses, are given in Foldout III in the cover pocket of this volume.

\section{Sediments}

Unit 1 - Marly Nannofossil Ooze and Nannofossil Ooze ( $<$ 50.8-202.0 m)

\section{Sub-Unit 1A}

This sub-unit is composed of Eocene marly nannofossil ooze and nannofossil ooze containing an average of 52 per cent $\mathrm{CaCO}_{3}$ in Cores 1 through 4 . The clay content is 36 per cent and nannofossils make up 49 per cent of the sediment. These and other components are summarized in Table 3 and are detailed in Foldout III (cover pocket).

The stratigraphic distribution of $\mathrm{CaCO}_{3}$ in the main lithology (Figure 8) is fairly uniform in Cores 1 to 4 , but in Core 5 it rises sharply to a maximum of 90 per cent. A thin, brecciated chert bed occurs in the lower part of Core 5. The core catcher contains $22 \mathrm{~cm}$ of limestone which is progressively more silicified towards the bottom. Core 5 had only 50 per cent recovery, and the easy brecciation of the chert by drilling suggests that there may have been other chert layers which were fractured and washed away. Two adjacent pieces of limestone in the core catcher had small pieces of in situ chert attached to their opposing faces, indicating that there originally was a chert bed between them. The silicified limestone in the core catcher is early Eocene in age, nannofossil Zone NP 13, and it is beneath this limestone that the boundary between Sub-units $1 \mathrm{~A}$ and $1 \mathrm{~B}$ is 


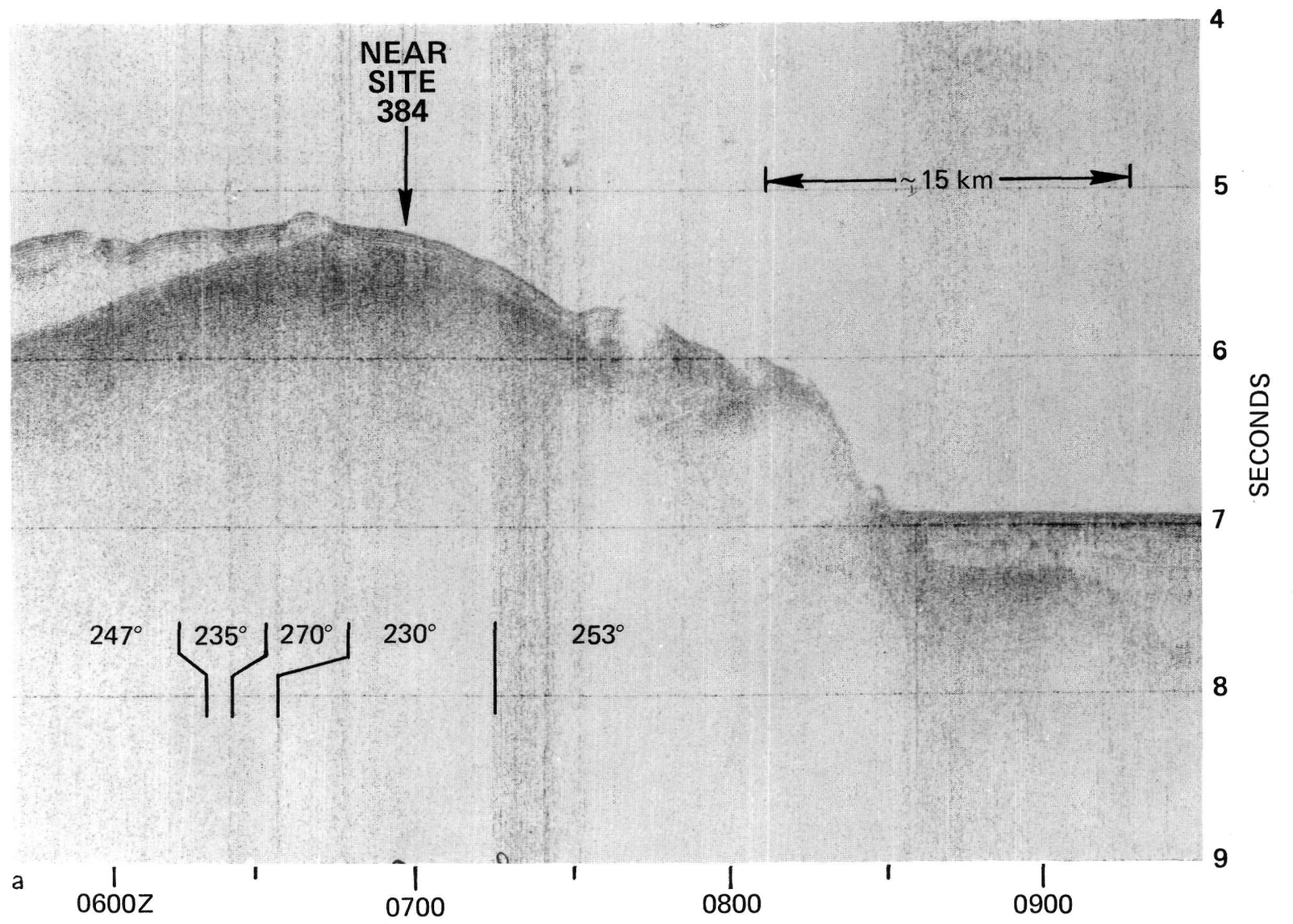

Figure 6. Glomar Challenger profiler record obtained during survey after drilling of the site (a), and interpretation (b). Location of profile shown in Figure 4.

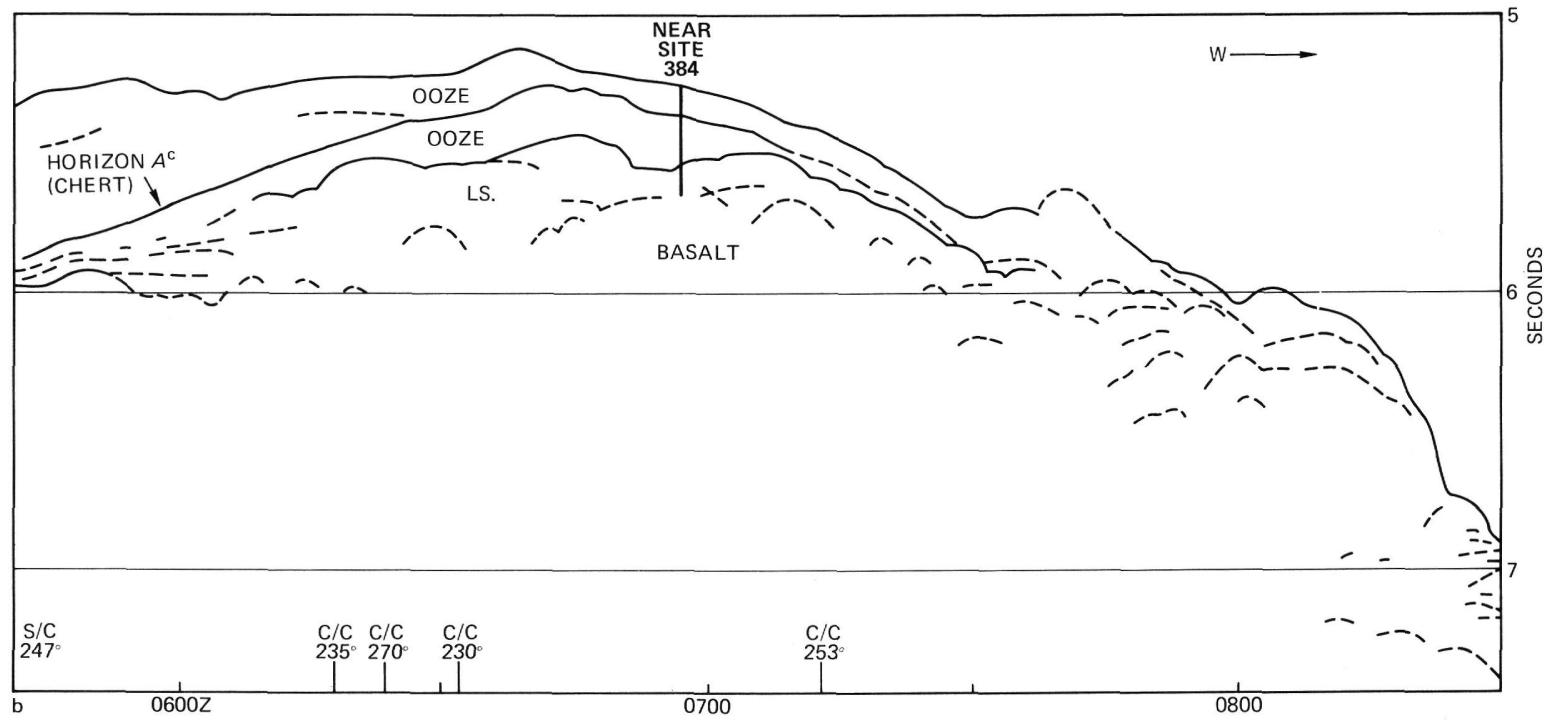

Figure 6. (Continued).

placed. The chert and silicified limestone marks Horizon $A^{c}$ at this site. An apparent hiatus of about 10 m.y. between Cores 5 and 6 separates Sub-units $1 \mathrm{~A}$ and $1 \mathrm{~B}$.

Minor lithologies in Sub-unit 1A include browner layers and patches and some white patches in Core 5 . The brown patches are of the same composition as the main lithology, but they contain slightly more iron oxide. The lithology of white patches is outlined below.

\section{Sub-Unit 1B}

This sub-unit is composed of Paleocene nannofossil ooze and chalk having a carbonate content in the upper 


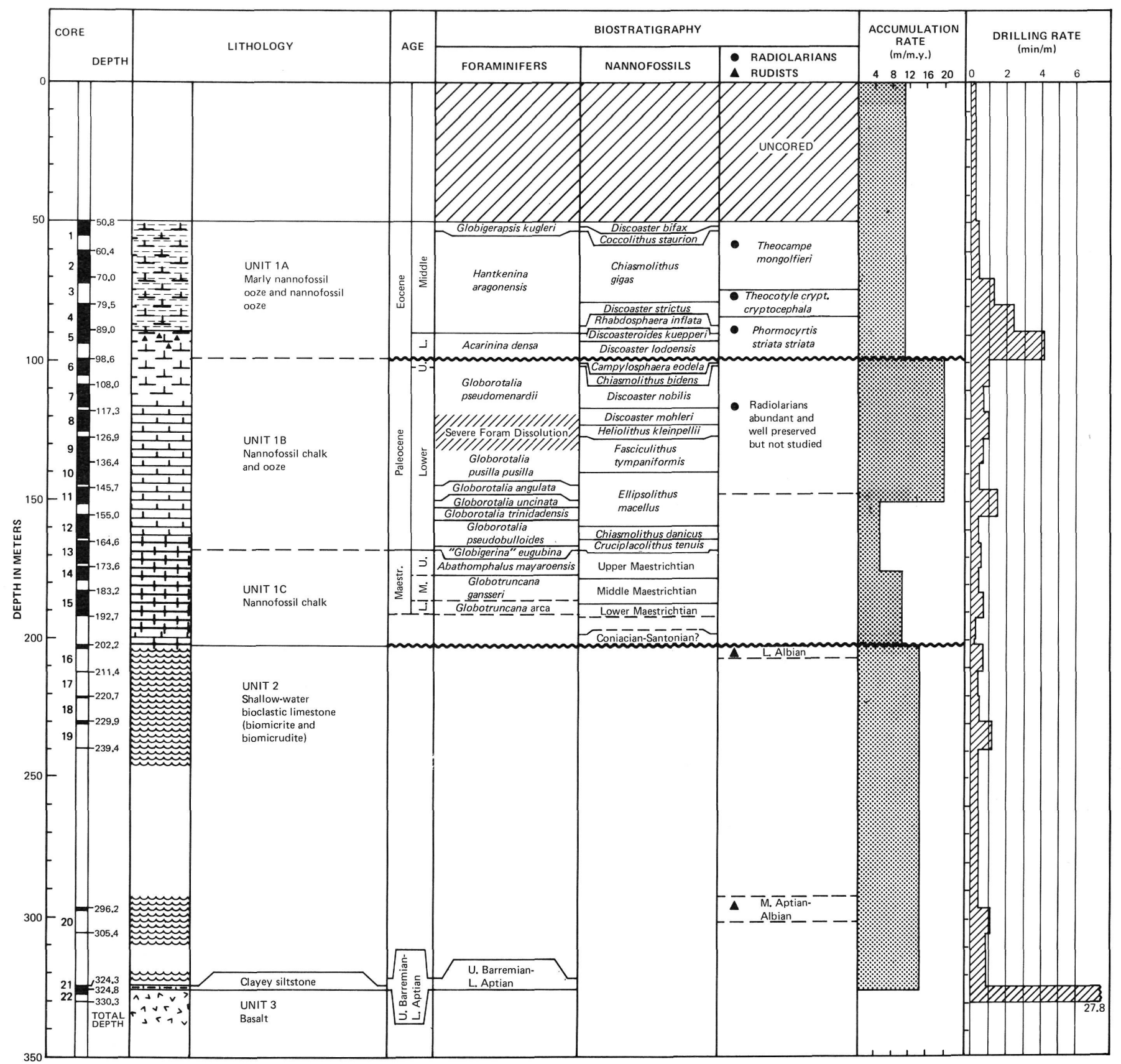

Figure 7. Graphic hole summary for Site 384.

part varying from 66 to 78 per cent, averaging 72 per cent, but with a gradient from 69 per cent at 153 meters to 91 per cent at 173 meters. The sub-unit has more nannofossils, less clay, and fewer radiolarians than Subunit 1A. From Core 7, Section 2 to the base of the subunit the sediment is moderately mottled with spots and lines of brown (maximum darkness 10YR 4/3). Smear slides show that these mottles are of average nannofossils ooze composition, but they have 1 to 2 per cent amorphous iron oxide and/or opaques including hematite.

The lower boundary of this sub-unit is placed at 33 $\mathrm{cm}$ in Core 13, Section 3 where a subtle color change from darker yellow $(2.5 Y$ 7/3) above to lighter yellow $(2.5 Y$ 8/3) below occurs (Figure 9). Below this level the sediment contains $>98$ per cent Maestrichtian nannofossils, and Tertiary forms become increasingly abundant above, in a zone of mixing.

In the lowermost part of Sub-unit 1B the content of unspecified carbonate rises to over 50 per cent and the nannofossil content drops to less than 25 per cent (see smear summary foldout, smears $13 / 2-140$ to $13 / 3-30$ ). Foraminifers in the same interval do not show any solution effects, so the changes in nannofossil content do not appear to reflect solution and re-precipitation. There is no cementation in this interval. The increased unspecified carbonate could be crushed foraminifer debris produced in the making of the smear slides because early Danian foraminifers are more fragile and thinner shelled than later forms. 
TABLE 2

Lithologic Units at Site 384

\begin{tabular}{|c|c|c|c|c|c|}
\hline Unit & Lithology & Age & $\begin{array}{l}\text { Thickness } \\
\text { (m) }\end{array}$ & $\begin{array}{l}\text { Sub-Bottom } \\
\text { Depth at } \\
\text { Bottom } \\
\text { of Unit (m) }\end{array}$ & Cores \\
\hline $1 \mathrm{~A}$ & $\begin{array}{l}\text { Marly nannofossil ooze } \\
\text { and nannofossil ooze }\end{array}$ & Eocene & $>48$ & 98.6 & 1 to 5 \\
\hline 1B & Nannofossil chalk and ooze & Paleocene & 69.3 & 167.9 & 6 to $13-3 / 33$ \\
\hline $1 \mathrm{C}$ & Nannofossil chalk & Maestrichtian & 34.1 & 202 & $\begin{array}{l}13-3 / 33 \text { to } \\
16-1\end{array}$ \\
\hline 2 & $\begin{array}{l}\text { Limestone (biomicrite } \\
\text { and biomicrudite) }\end{array}$ & $\begin{array}{l}\text { Upper Barremian - } \\
\text { (?) Lower Albian }\end{array}$ & 123 & 324.8 & $16-1$ to 21 \\
\hline 3 & Basalt & $\begin{array}{l}\text { Upper Barremian- } \\
\text { Lower Aptian }\end{array}$ & $>2.35$ & - & 22 \\
\hline
\end{tabular}

TABLE 3

Major Components and Dominant Lithologies in Unit 1 From Smear Slides, Carbonate Bomb, and X-Ray Diffraction

\begin{tabular}{lccccccc}
\hline \multicolumn{1}{c}{ Sub-Unit } & Nannos & Clay & K/I/C/M & $\begin{array}{c}\text { Unspecified } \\
\text { Carbonate }\end{array}$ & Foraminifers & Rads & $\begin{array}{c}\text { Carbonate } \\
\text { Bomb }\end{array}$ \\
\hline $\begin{array}{l}\text { 1A } \\
\text { Cores 1-4, Section 4 }\end{array}$ & 49 & 36 & $9 / 24 / 5 / 62$ & 4 & - & 10 & $52 \%$ \\
$\begin{array}{l}\text { 1A } \\
\text { Core 4, Section 5-5 }\end{array}$ & 58 & $28(19)$ & & 9 & - & 4 & $76 \%(62 \%$ incr. \\
1B & 60 & $27(22)$ & $4 / 11 / 3 / 82$ & 5 & 2 & 5 & $72 \%$ \\
1C & 65 & $16(7)$ & $4 / 38 / 2 / 56$ & 6 & 12 & - & $92 \%$ \\
\hline
\end{tabular}

Note: Clay figures in parentheses are corrected values suggested by carbonate bomb results. $\mathrm{K} / \mathrm{I} / \mathrm{C} / \mathrm{M}$ stands for kaolinite, illite, chlorite, montmorillonite, the values being expressed as percentages of the clay-size $(<2$ $\mu \mathrm{m})$ fraction.

The faunal content of Sub-unit 1B includes the upward appearance of radiolarians as a significant component in Core 11 (Danian); they average 6 per cent from Core 6 to Core 11. Foraminifers are rare in smear slides in Cores 6 to 9, but they are increasingly abundant from Core 10 downwards, though it should be noted that smear-slide estimates are not truly representative of actual concentrations.

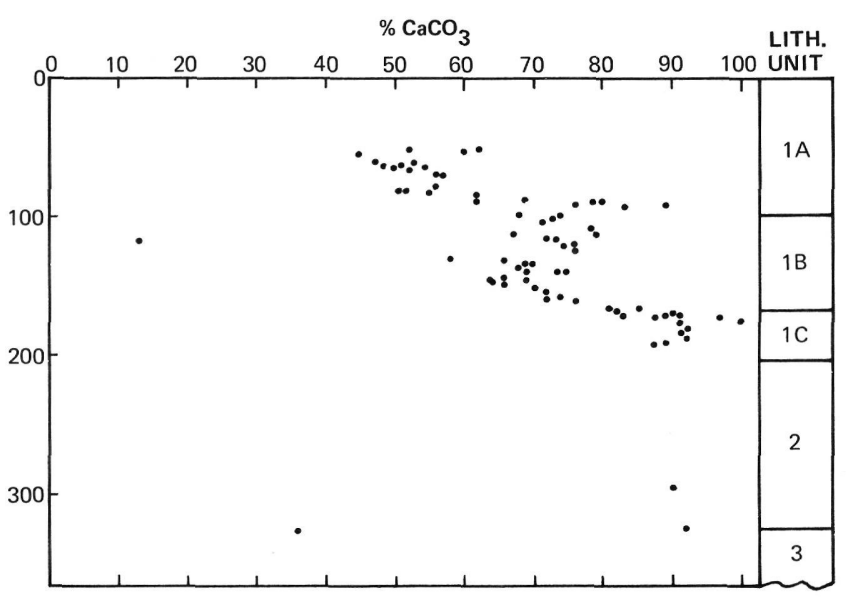

Figure 8. $\mathrm{CaCO}_{3}$ content of sediments at Site 384 from shipboard measurements (Table 6) and data from Koch and Rothe, and Cameron (this volume).
Minor lithologies in Sub-unit 1B, apart from the brown burrow mottles noted above, include white patches also found in Core 5 and Sub-unit 1C. The average composition of 14 smear slides of white patches is 60 per cent nannofossils, 26 per cent clay, 5 per cent unspecified carbonate, and 8 per cent radiolarians. Only the radiolarian content is slightly higher than the average material of Sub-unit 1B (Table 3). One example was noted of a white patch cut by a burrow filled with pale yellow host sediment. Other occurrences of white are as irregular patches, as layers up to a few $\mathrm{cm}$ thick, and as concentric ellipses with yellow host sediment at the center. Some contain black (manganese oxide?) spots while others have a "halo" of pale sediment around them. They seem to be syndepositional or very early post-depositional and may represent reworking by benthos that resulted in bleaching of host sediment.

\section{Sub-Unit 1C}

Sub-unit $1 \mathrm{C}$ is very pale yellow nannofossil chalk with 12 per cent foraminifers estimated from smear slides. Carbonate content $(\sim 90 \%)$ is higher than in Sub-unit 1B, and there is a distinct, gradual increase in carbonate in the lower part of $1 \mathrm{~B}$, across the Cretaceous/Tertiary boundary, and into the Maestrichtian Sub-unit 1C. The only minor lithology in $1 \mathrm{C}$ is the white material described above for Sub-unit 1B. The lower boundary of Sub-unit $1 \mathrm{C}$ presumably is the contact with the shallow-water limestones of Unit 2. We say 

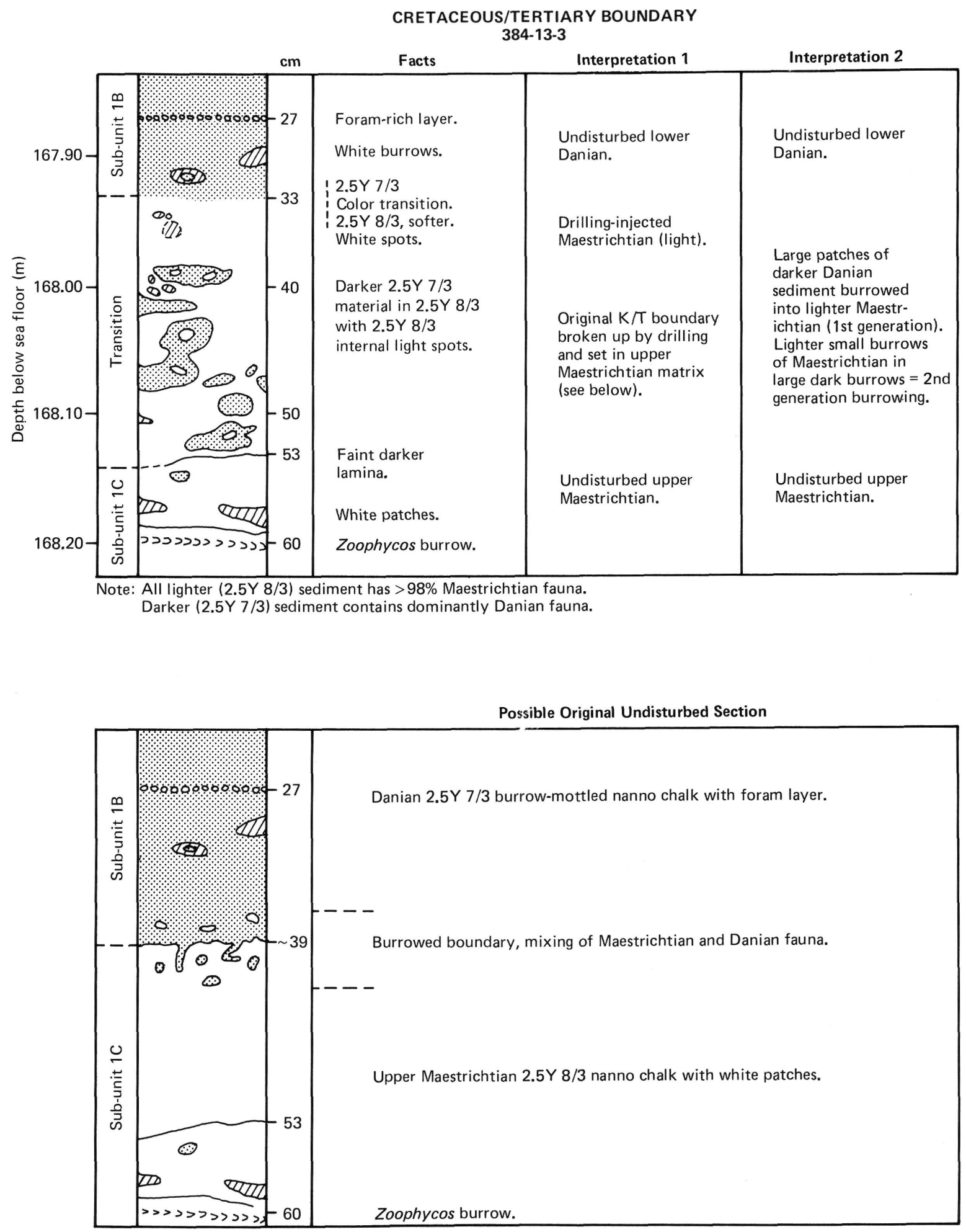

Figure 9. Interpretation of Cretaceous/Tertiary boundary at Site 384, Core 13, Section 3. Reconstructed section (lower) assumes Interpretation 1 (drilling disturbance) is correct.

presumably because the oldest Sub-unit $1 \mathrm{C}$ material in Core 15 is lower Maestrichtian whereas a minor quantity of brown nannofossil ooze associated with shallowwater limestone in Core 16 contains a ConiacianSantonian nannofossil assemblage. The recovery in Core
16 was very poor and a 10 -meter-interval between Cores 15 and 16 was not cored. There probably is a hiatus of about 20 m.y. between Units 1 and 2 in Core 16, and there may be an additional hiatus or hiatuses in the uncored interval between Cores 15 and 16 . 


\section{Unit 2-Bioclastic Limestone (202.0-324.8 m)}

Samples of Unit 2 are very sparse, and no undisturbed rock was recovered. In discussing these limestones the terminology of Folk $(1959,1962)$ is used. This classification groups limestones according to whether they have microcrystalline calcite matrix (micrite) or sparry calcite cement (sparite); the former indicates conditions of little winnowing, permitting accumulation of lime mud, and the latter indicates an origin in agitated environments where the originally clear pore space subsequently acquired sparry cement. Subdivision of the sparites and micrites is based on the content of "allochem" grains-oolites, fossil fragments, fecal pellets, and intraclasts.

The bioclastic limestones of Unit 2 found in Cores 16 to 21 range in age from late Barremian-early Albian to (?) early Aptian (see Biostratigraphy). They include coarse carbonate sand with skeletal debris, and biomicrite, intrabiomicrite, biomicrudite, and intrabiosparudite. Some of the biomicrites are partly dolomitized. The principal depositional features of these rocks are (1) poor sorting with an admixture of lime mud and large broken and whole fossils, and (2) a diverse fauna and flora including rudists, other pelecypods, gastropods, echinoderms, ostracodes, foraminifers, bryozoans, solitary corals, and red algae. The principal diagenetic features are (1) high moldic porosity from solution of most aragonite skeletons (mainly pelecypods), (2) partial infilling of molds by spar, (3) micritic envelopes and micritization rims with boring canals around some grains, and (4) partial dolomitization of some skeletal grains and some micrite matrix (see Rothe, this volume).

These features suggest deposition in relatively quiet water where lime mud could accumulate, but near agitated water where a ready supply of broken shells, some of them heavy varieties, would be produced. Thus the most likely site is a back-reef environment such as that in the Florida reef tract (Ginsburg, 1956). Micritization rims occur only in shallow water and dolomitization may have occurred just above sea level in the supratidal environment. The development of moldic porosity requires exposure to meteoric waters. This interpretation is reinforced by light $\delta^{18} \mathrm{O}$ values in the limestones, which are thought to result from rainwater isotopic exchange during subaerial exposure (Rothe and Hoefs, this volume). This exposure could be achieved either by uplift of the ridge or a fall in sea level. Because of the poor core recovery in the limestones, it is not possible to determine whether the entire unit was simultaneously exposed above sea level or whether only certain elements were episodically exposed.

At the base of Unit 2 (Sample 21, CC), $8 \mathrm{~cm}$ of bedded dark blue-green clayey siltstone and claystone, partly supported by a crude, crystalline framework, were recovered. The original thickness of this rock type was greater than $8 \mathrm{~cm}$ because pieces of it occur in Section 1 of Core 21, but it was certainly much less than 9.5 meters thick because more limestone than blue-green claystone was recovered in the core. The rock consists mostly of clay stained with amorphous iron oxides. $\mathrm{X}$-ray diffraction analysis indicates the $<2 \mu \mathrm{m}$ fraction of the clay is 100 per cent montmorillonite. The clays encase clasts of altered basalt ranging from about 0.1 $\mathrm{mm}$ in diameter up to $0.9 \mathrm{~mm}$ by $1.26 \mathrm{~mm}$ in angular fragments. Most clasts are angular to subangular and about $0.3 \mathrm{~mm}$ in size. Smaller clastic debris includes single phyric crystals of plagioclase (An 72) and spherules of montmorillonite, calcite, chlorite, and iron oxides in varying proportions which represent vesicle fillings. The silty clay is distinctly bedded in a repeated sequence of fine clay overlying a coarser horizon, suggesting secondary deposition around erosional igneous debris. Basaltic clasts are extremely altered with a groundmass consisting almost entirely of montmorillonite and chlorite; only a few plagioclase microlites are recognizable. Phenocrysts of plagioclase are rare. Vesicularity is on the order of 20 to 30 per cent. Some chloritic-calcic debris is very angular, resembling infilling of multiple vesicles. The delicacy of such materials argues against transport unless the cementation occurred after initial emplacement. These fillings are, however, reminiscent of the cement in volcaniclastic breccias such as those drilled at Sites 382 and 385 .

The framework structure is composed of an interlocking system of zeolitic and calcitic veinlets up to $0.02 \mathrm{~mm}$ thick. The structure is crudely geometric in shape, rarely assuming a ladder form (Figure 10) with its long axis along "bedding" planes. The density of such veinlets is only slightly greater than that found in the underlying basalt.

The material suggests an origin as basaltic "soil" produced by the weathering of fractured, vesicular basaltic material. The thinness of the rock, the presence only of minerals that can be formed from alteration of basalt, the remnant basalt clasts, and the similarity of vein structure in the rock and in the underlying basalt all support this conclusion.

The contact between this basal part of Unit 2 and the underlying basalt is placed at $\mathbf{3 2 4 . 8}$ meters. Thus, the contact occurs between Cores 21 and 22 and it was not recovered intact.

\section{Discussion}

The age, composition, and depositional environment of the bioclastic limestones are discussed in detail by Rothe (this volume), Schroeder and Cherchi (this volume), and by Perkins (this volume). Ages range from late Barremian-earliest Aptian at the base to (?) early Albian at the top of the limestones. Deposition was in a relatively quiet, restricted, shallow-water environment,

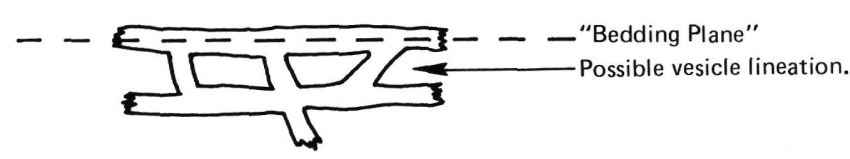

Figure 10. Primitive geometric lattice of vein calcite displayed along "bedding" planes of greenish blue silty claystone in Core 21, Core Catcher. 
and the assemblage can be interpreted as a back-reef facies. In fact, the seismic profile across Site 384 (Figure 6) suggests that the drill string did penetrate the limestones in a "back-reef" position behind higher reef banks that sheltered the site from the open ocean. The termination of reef growth could have been caused by any of several factors: (1) failure of reef upbuilding to keep pace with subsidence, (2) drowning during the worldwide Cenomanian transgression, or (3) subaerial exposure caused by tectonic uplift or by a sea-level drop in the late Aptian (Vail et al., 1977), followed by rapid submergence. The third alternative in some form is favored because of evidence that the reef was exposed to meteoric water (Rothe; and Rothe and Hoefs, this volume).

After the demise of the reef and its final submergence, little or no sediment accumulated for about 20 m.y. until Coniacian/Santonian time when the $J$-Anomaly Ridge probably had subsided to depths greater than $2 \mathrm{~km}$. It is possible that shallower ocean currents kept the reef relatively free of sediment during this interval. A 9.5-meter-interval between the Coniacian/ Santonian nannofossil ooze in Core 16 and lower Maestrichtian chalks in Core 15 was uncored. If accumulation was continuous during this interval, it was at very low rates of about $1 \mathrm{~m} / \mathrm{m}$.y., but it is not unlikely that one or more hiatuses are present.

Maestrichtian through early Paleocene (Cores 5 to 11 ) are about $6-10 \mathrm{~m} / \mathrm{m} . \mathrm{y}$. and carbonate content shows a regular decrease from about 90 to 70 per cent in this interval (Figure 8). The upper lower and lower upper Paleocene sediments (Cores 10 to 6) accumulated more rapidly ( $\sim 20 \mathrm{~m} / \mathrm{m} . \mathrm{y}$.$) and have a rather uniform car-$ bonate content at about 70 per cent. Upper lower to lower middle Eocene sediments (Cores 5 to 1 ) show a decrease in accumulation rate $(\sim 11 \mathrm{~m} / \mathrm{m} . \mathrm{y}$.$) and$ decrease in carbonate content (Figure 8). The steadily decreasing carbonate content from Maestrichtian through Eocene probably reflects a slight but general increase in carbonate dissolution as the $J$-Anomaly Ridge subsided.

The Cretaceous/Tertiary boundary at Site 384 is remarkable in that we have no physical evidence suggesting a change in depositional conditions across the boundary apart from the appearance above the bound-

ary of burrow mottles and a very slight color change. In terms of carbonate content, the boundary falls in the middle of a smooth transition. There is no evidence for solution caused by a shoaling of the CCD as suggested by Worsley (1974), no hardground (cemented horizon), no phosphate nodules, little evidence for a hiatus and no sharp change in the carbonate accumulation rate. The difference in the clay accumulation rate between the Maestrichtian and Paleocene was achieved gradually rather than abruptly. The high content of unspecified carbonate and reduced content of nannofossils in the few smear slides above the boundary seem not to indicate solution and redeposition because there is no cementation and no pitting of foraminifers. The only change that can be inferred from lithology is that the sediment may have been "suddenly" colonized by a burrowing organism which left a residue in its burrows that would promote diagenetic formation of amorphous iron oxide. Alternatively, the slight color change to a little darker yellow in the Paleocene may mean a generally higher level of iron in the sediment, and a corresponding segregation of iron oxide in burrow traces. In either case, the geochemical and sedimentological changes across the Cretaceous/Tertiary boundary were not severe at Site 384. Possible interpretations of disturbance of the $\mathrm{K} / \mathrm{T}$ boundary by drilling or burrowing are shown in Figure 9.

There is a hiatus spanning about $10 \mathrm{~m} . \mathrm{y}$. between the silicified limestone/chert (Horizon $A^{C}$ ) at the bottom of Core 5 (lower Eocene) and the nannofossil ooze in the top of Core 6 (upper Paleocene). This hiatus, and the high productivity of siliceous and calcareous plankton indicated by the chert and the carbonate peak in Core 5 (Figure 8) may be associated with early development of intensified circulation. However, slumping as a cause for the hiatus cannot be excluded.

The clay-mineral composition of the calcareous ooze in Unit 1 is given in Table 3. Kaolinite and chlorite are subsidiary, never being more than 12 per cent with the sole exception of a kaolinite value of 17 per cent in the uppermost sample at 1-1-120. Montmorillonite dominates all the samples, particularly those of the Paleocene Sub-unit 1B. Illite (clay mica) is important in Sub-units $1 \mathrm{~A}$ and $1 \mathrm{C}$, but in $1 \mathrm{~B}$ values as low as 5 per cent are found. Holocene sediment in this area and on the New England continental rise typically has a montmorillonite/illite ratio of between 1 and 3 (Zimmerman, 1972; Piper, 1975). Values of the M/I ratio in Sub-units $1 \mathrm{~A}$ and $1 \mathrm{C}$ are similar to Holocene values, but those of the Paleocene Sub-unit 1B are much higher, over 10 in some cases. Possibly some additional source (? volcanic) of montmorillonite was available during the Paleocene (see Tucholke and Vogt, this volume).

\section{Basalt}

Basalt (lithologic Unit 3) at Site 384 was encountered at a sub-bottom depth of 324.8 meters. It was cored an additional 5.5 meters (Core 22) to a total hole depth of 330.3 meters.

\section{Megascopic and Petrographic Description}

The basalt recovered is a hypocrystalline, finegrained, amygdaloidal, phyric basalt with common pyroxene $(0.4-2.0 \mathrm{~mm})$ and rare plagioclase phenocrysts (An 70-75; 0.5-0.8 mm). Colorless to pale purplish brown, subhedral, prismatic crystals of augite $(n=1.70)$ dominate $(8-15 \%)$ the phenocryst phases. Rare patches of bowlingite suggest the former existence of an olivine phenocryst phase. The groundmass consists of pyroxene $(10-20 \%)$ and poikilitic plagioclase with rare, partly devitrified, brown glass in a pilotaxitic 
(diabasic) texture, displaying minor fluction of plagioclase microlites around phenocrysts and amygdules. Secondary minerals occupying intersertal positions and replacing former crystal boundaries are abundant. Elliptical amygdules of calcite, montmorillonite, and/or zeolite up to $5.0 \mathrm{~mm}$ across constitute 10 to 25 per cent of the rock. Vesicles commonly are lined with iron oxides and chlorite, possibly derived from the devitrification of palagonitic rims. Numerous thin calcite-chlorite-zeolite veinlets $(0.02-0.1 \mathrm{~mm})$ with epidote-chlorite encrusted slickensides occur throughout the basalt.

The recovered section is divided into three sub-units on the basis of color (Figure 11). These color changes also correlate with density variations (Table 4). Contacts between these sub-units are disrupted greatly by drilling and intense calcite veining. Although three flows may be represented by this sequence, only variations in alteration are recognizable petrologically.

The uppermost color sub-unit (325.9-327.0 m subbottom) is distinguished by partial alteration of groundmass and phyric augite to montmorillonite with or without calcite. Alteration is usually most intense along cleavage planes where irregular bleaching is observed. Magnetite $(<1 \%)$ in places lines augite crystal boundaries. About 15-25 per cent of groundmass plagioclase is altered to montmorillonite.

Sub-unit 3B (327.0-328.05 m sub-bottom) contains more iron oxides, less montmorillonite, and fresher groundmass plagioclase, accounting for its lighter brown color. Plagioclase phenocrysts tend to be optically cloudy but display only slight alteration to montmorillonite. Pyroxenes, however, are substantially altered. Vesicles are completely filled with olive-green

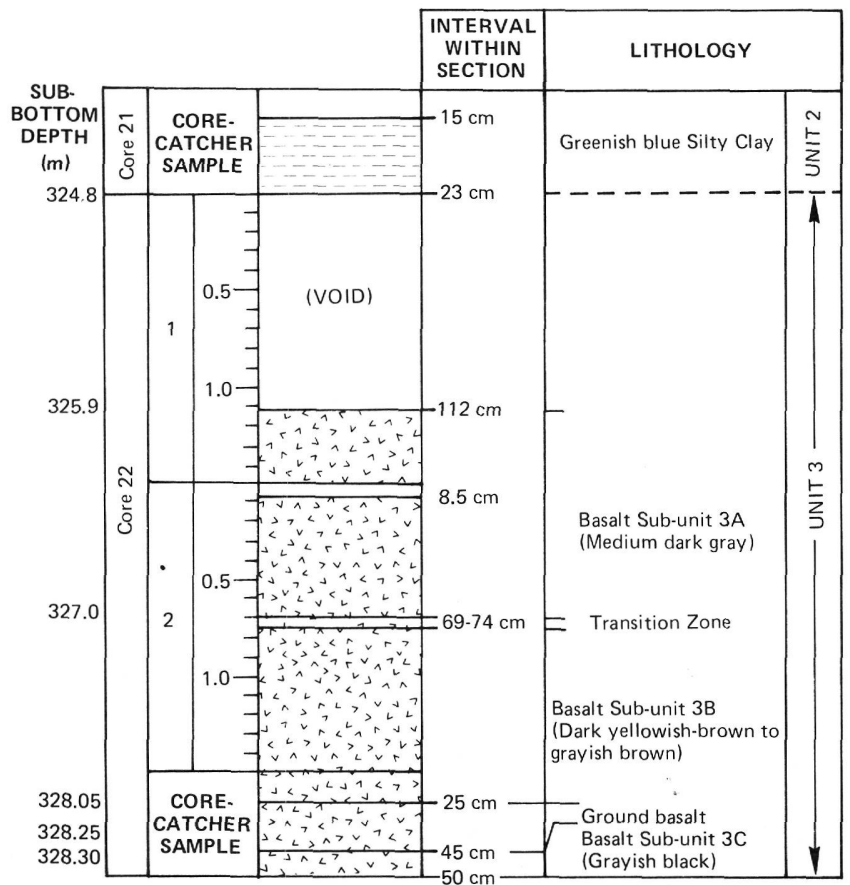

Figure 11. Sub-division of basalt (lithologic Unit 3) recovered at Site 384.
TABLE 4

Basalt Densities, Site 384

\begin{tabular}{lcl}
\hline $\begin{array}{c}\text { Sample } \\
\text { (Interval in cm) }\end{array}$ & Density $^{\mathrm{a}}$ & \\
\hline $22-1,118-120$ & 2.61 & \\
$22-1,128-130$ & 2.69 & \\
$22-2,14-16$ & 2.63 & Sub-unit A \\
$22-2,25-27$ & 2.66 & \\
$22-2,35-37$ & 2.62 & \\
$22-2,56-58$ & 2.55 & \\
$22-2,64-66$ & 2.52 & Transitional (vein) \\
$22-2,80-82$ & 2.60 & \\
$22-2,106-108$ & 2.59 & Sub-unit B \\
$22-2,127-129$ & 2.55 & \\
22, CC, $9-11$ & 2.57 & \\
22, CC, $46-48$ & 2.65 & Sub-unit C \\
\hline a Densities in g/ cm $^{3}$; determined by weight-in-air \\
weight-in-water methods.
\end{tabular}

montmorillonite with lesser calcite and zeolite. Chlorite may be occasionally important where veins intersect former vesicles. This relationship is especially true in the $5 \mathrm{~cm}$ transition zone between Sub-units 3A and 3B. Structural relations are completely obscured in this region by extensive calcite veining and heavy masking by chlorite.

The lowest basalt (328.25-328.30 m sub-bottom) is separated from Sub-unit 3B by $20 \mathrm{~cm}$ of basalt brecciated during drilling. There are no calcite fragments to suggest veining in this region, and a second weathering zone may have been present. Augite phenocrysts in Sub-unit $3 \mathrm{C}$ basalt are generally clear and are rarely clouded by uralitization. Plagioclase phenocrysts also are generally fresh, although groundmass feldspar is altered to montmorillonite where intersertal to pyroxene. Chlorite and montmorillonite fill vesicles. Calcite veinlets commonly contain a significant chlorite component.

\section{Discussion}

Basement rocks at Site 384 are moderately diabasic basalts, partially chloritized, zeolitized, calcified, and uralitized. Mineralogy is consistent with an oceanic tholeiite. Geochemical relations confirm this classification. All contacts, including that with the overlying Unit 2 , are absent. Fluction of plagioclase microlites and the basalt's high vesicularity $(10-25 \%)$ are consistent with extrusion of a flow at relatively shallow depths (less than $2000 \mathrm{~m}$ ).

Groundmass and amygdule chlorite and extensive calcite veining suggest all recovered basalt has been hydrothermally altered. The effects of this event appear to be most intense in the vicinity of veins. Sub-unit 3A probably represents a zone of low-temperature alteration superimposed upon this basalt. Sub-unit 3C may represent another flow having its superimposed alteration zone within the overlying drilling breccia, but it is petrographically analogous to the other sub-units, although less affected by alteration.

The relationship of the basalt to the high-amplitude " $J$-Anomaly" is difficult to evaluate. It is uncertain if 
the 2.35 meters of basalt recovered is representative of the remaining pillow section. Opaque mineral concentrations are not unduly high, and do not suggest a source of high magnetic potential. The tholeiitic tendency of the basalt, however, is consistent with a ridge origin.

The reader is referred to individual shore-lab reports in this volume for detailed information on the magnetism, petrochemistry, and radiometric ages of the Site 384 basalt.

\section{GEOCHEMISTRY}

\section{Carbon, Nitrogen}

Both shipboard and post-cruise measurements indicate that the sediments at Site 384 contain very little $(<0.1 \%)$ organic carbon (Table 5; see also Cameron, this volume). Because the carbon and nitrogen contents of the samples were close to the detection limit of the instrument, it was not possible to compute meaningful $\mathrm{C} / \mathrm{N}$ ratios.

\section{Calcium Carbonate}

The shipboard $\mathrm{CaCO}_{3}$ determinations for Site 384 are listed in Table 6, and they are summarized in Figure 8, together with laboratory measurements. Shipboard carbonate determinations were made using the "carbonate bomb" (Müller and Gastner, 1971). The significance of trends in carbonate content is discussed in the Lithology section.

\section{Interstitial Water Chemistry}

Four interstitial water samples were collected at Site 384 , and the analytical results are summarized in Table 7. The Tertiary sediments from which the samples were taken have uniform pore water chemistry.

\section{Interstitial Gases}

Cores 10 and 13 contained greater than normal amounts of gas, as indicated by bulging end caps on the cores. Several gas samples were collected for analysis on a Carle gas-chromatograph. Unusually large amounts of $\mathrm{CO}_{2}$ were detected, but no hydrocarbons were present. Using a gas standard provided by Phillips Petroleum Company, the $\mathrm{CO}_{2}$ contents were found to vary between 1200 and 3500 ppm by volume.

\section{TABLE 5}

Shipboard Organic Carbon, Nitrogen Measurementsa ${ }^{a}$, Site 384

\begin{tabular}{cccc}
\hline $\begin{array}{c}\text { Sample } \\
\text { (Interval in cm) }\end{array}$ & $\begin{array}{c}\text { Depth Below } \\
\text { Sea Floor (m) }\end{array}$ & $\% \mathrm{C}_{\text {org }}$ & $\% \mathrm{~N}$ \\
\hline $1-2,124$ & 53.5 & $<0.1$ & 0.01 \\
$5-2,130$ & 91.8 & $<0.1$ & 0.01 \\
$10-3,150$ & 140.9 & $<0.1$ & 0.01 \\
$15-4,130$ & 188.8 & $<0.1$ & 0.01 \\
\hline additional shore-lab data are given by Cameron (this \\
volume).
\end{tabular}

TABLE 6

Shipboard $\mathrm{CaCO}_{3}$ Measurements ${ }^{\mathrm{a}}$, Site 384

\begin{tabular}{|c|c|c|}
\hline $\begin{array}{c}\text { Sample } \\
\text { (Interval in } \mathrm{cm} \text { ) }\end{array}$ & $\begin{array}{l}\text { Depth Below } \\
\text { Sea Floor } \\
(\mathrm{m})\end{array}$ & $\% \mathrm{CaCO}_{3}$ \\
\hline $\begin{array}{l}1-1,70-71 \\
1-2,124-125 \\
1-3,100-101 \\
2-2,75-76 \\
2-3,20-21\end{array}$ & $\begin{array}{l}51.5 \\
53.5 \\
54.8 \\
62.7 \\
63.6\end{array}$ & $\begin{array}{l}62 \\
60 \\
45 \\
53 \\
48\end{array}$ \\
\hline $\begin{array}{l}2-6,20-21 \\
3-1,100-101 \\
4-3,60-61 \\
4-6,127-128 \\
5-1,140-141\end{array}$ & $\begin{array}{l}68.1 \\
71.0 \\
83.1 \\
88.3 \\
90.4\end{array}$ & $\begin{array}{l}50 \\
57 \\
51 \\
62 \\
80\end{array}$ \\
\hline $\begin{array}{l}5-2,120-121 \\
5-3,138-139 \\
5, C C, 0-1 \\
5, C C, 15-17 \\
6-1,91-92\end{array}$ & $\begin{array}{l}91.7 \\
93.4 \\
93.6 \\
93.8 \\
99.5\end{array}$ & $\begin{array}{l}76 \\
89 \\
83 \\
13 \\
68\end{array}$ \\
\hline $\begin{array}{l}6-2,99-100 \\
6-3,86-87 \\
6-4,142-143 \\
7-2,21-22 \\
7-4,53-54\end{array}$ & $\begin{array}{l}101.1 \\
102.5 \\
104.5 \\
109.7 \\
113.0\end{array}$ & $\begin{array}{l}71 \\
73 \\
71 \\
78 \\
67\end{array}$ \\
\hline $\begin{array}{l}7-6,88-89 \\
8-5,24-25 \\
9-3,133-134 \\
9-5,93-94 \\
10-2,47-48\end{array}$ & $\begin{array}{l}116.4 \\
123.5 \\
131.2 \\
133.8 \\
138.4\end{array}$ & $\begin{array}{l}73 \\
74 \\
66 \\
69 \\
69\end{array}$ \\
\hline $\begin{array}{l}10-3,82-83 \\
10-6,143-144 \\
11-2,48-49 \\
11-4,11-13 \\
12-2,24-25\end{array}$ & $\begin{array}{l}140.2 \\
145.3 \\
147.7 \\
150.3 \\
156.7\end{array}$ & $\begin{array}{l}74 \\
66 \\
64 \\
66 \\
72\end{array}$ \\
\hline $\begin{array}{l}12-5,19-20 \\
13-2,19-20 \\
13-2,82-83 \\
13-4,32-33 \\
13-4,60-61\end{array}$ & $\begin{array}{l}161.2 \\
166.3 \\
166.9 \\
169.4 \\
169.7\end{array}$ & $\begin{array}{l}72 \\
81 \\
82 \\
83 \\
88\end{array}$ \\
\hline $\begin{array}{l}13-5,137-138 \\
13-6,120-121 \\
14-2,25-26 \\
15-1,4-5 \\
15-3,90-91\end{array}$ & $\begin{array}{l}172.0 \\
173.3 \\
175.4 \\
183.2 \\
187.1\end{array}$ & $\begin{array}{r}97 \\
91 \\
100 \\
92 \\
92\end{array}$ \\
\hline $\begin{array}{l}15-6,140-141 \\
20, C C, 5-6 \\
21-1,110-111 \\
21-1,130-131\end{array}$ & $\begin{array}{l}192.1 \\
297.8 \\
325.4 \\
325.6\end{array}$ & $\begin{array}{l}89 \\
90 \\
92 \\
36\end{array}$ \\
\hline
\end{tabular}

${ }^{\mathrm{a}}$ Carbonate bomb method. Additional shorelab data are given by Koch and Rothe (this volume) and Cameron (this volume).

\section{PHYSICAL PROPERTIES}

Compressional wave velocity, wet bulk density, undrained shear strength, thermal conductivity, and other bulk properties such as water content and porosity were measured on the core samples obtained at Site 384 . These data are tabulated in Table 8. The shipboard methods for determining these parameters are given in the Physical Properties section of the Site 382 Report along with the associated systems errors. Because of 
TABLE 7

Interstitial Water Chemistry, Site 384

\begin{tabular}{lccccccc}
\hline $\begin{array}{c}\text { Sample } \\
\text { (Interval in cm) }\end{array}$ & $\begin{array}{c}\text { Depth Below } \\
\text { Sea Floor } \\
(\mathrm{m})\end{array}$ & $p \mathrm{H}$ & $\begin{array}{c}\text { Alkalinity } \\
(\mathrm{meq} / \mathrm{l})\end{array}$ & $\begin{array}{c}\text { Salinity } \\
(\%)\end{array}$ & $\begin{array}{c}\text { Chlorinity } \\
(\%)\end{array}$ & $\begin{array}{c}\mathrm{Ca}^{++} \\
(\mathrm{m} \mathrm{mole} / \mathrm{l})\end{array}$ & $\begin{array}{c}\mathrm{Mg}^{++} \\
(\mathrm{m} \mathrm{mole} / \mathrm{l})\end{array}$ \\
\hline Surface seawater & - & 8.79 & 2.35 & 35.2 & 19.3 & 10.7 & 54.0 \\
$1-2,144-150$ & 53.8 & 7.96 & 2.34 & 34.9 & 19.4 & 12.2 & 51.2 \\
$5-1,144-150$ & 90.5 & 7.97 & 2.48 & 35.2 & 19.4 & 12.7 & 51.5 \\
$8-4,144-150$ & 123.3 & 8.06 & 2.28 & 34.9 & 19.4 & 12.5 & 51.0 \\
$12-4,144-150$ & 161.0 & 7.96 & 2.15 & 34.9 & 19.5 & 12.6 & 50.7 \\
\hline
\end{tabular}

coring disturbance effects on sediment properties (Demars et al., this volume), only cohesive test specimens with minimum visual distortion were selected for measurement by other than the continuous GRAPE; test specimens are typically taken from the lower (leastdisturbed) sections of each core.

\section{Shear Strength}

Undrained shear strength as a function of depth is shown in Figure 12 for the relatively uniform calcareous ooze encountered at Site 384 . The data exhibit considerable scatter and do not show any of the expected increase in strength with sub-bottom depth. Instead, if this systematic increase does exist, it is masked by a dramatic increase in strength with depth in each core (9.6 m maximum length) as discussed by Demars et al. (this volume). Sample disturbance has a profound influence on the physical properties (especially strength) of nannofossil oozes because of their granular behavior. Strength measurements were terminated for samples deeper than about 100 meters because chalks below this depth fractured upon vane insertion.

\section{Bulk Properties}

There is a pronounced, almost linear decrease in water content with sub-bottom depth as the nannofossil ooze converts to a chalk at about 100 meters (Figure 13). This trend is expected as part of normal compaction and diagenetic processes. Unfortunately, data below about 200 meters are limited because of poor core recovery and disturbance in the shallow-water limestones.

For test specimens in the upper 140 meters, core section numbers are assigned to each water-content data point (Figure 13). In most cases the water contents from the upper sections of each core are as much as 10 to 12 per cent higher than in the lower core sections. It is clear that during the coring process, more water is incorporated in the nannofossil ooze in the upper core sections than in the lower sections. Because shear strength roughly is related inversely to water content, this trend helps to explain the erratic strength behavior noted above. The data by no means suggest that the bottom of each core is undisturbed or that water has not been added to the sediment, only that it is less disturbed than sediment from the top of the core.

\section{Density and Acoustic Velocity}

Wet bulk density, acoustic velocity, and acoustic impedance (density times velocity) also are presented in
Figure 13. The wet bulk densities average about 1.50 $\mathrm{g} / \mathrm{cm}^{3}$ for the ooze, $1.85 \mathrm{~g} / \mathrm{cm}^{3}$ for the chalk, and reach $2.12 \mathrm{~g} / \mathrm{cm}^{3}$ for an indurated chalk in Core 20, Section 1 . A 15-cm layer of silicified limestone was encountered at about 90 meters, reef-limestone fragments at about 230 meters, and basalt at about 325 meters; each had higher densities than the adjacent ooze/chalk (Figure 13). However, core recovery below 200 meters was poor and the test data are very limited.

Acoustic velocities increase almost linearly from about $1.50 \mathrm{~km} / \mathrm{sec}$ in the shallowest nannofossil oozes measured to about $2.2 \mathrm{~km} / \mathrm{sec}$ in the indurated chalk in Core 20. The silicified limestones in Core 5 have velocities of 1.81-1.94 km/sec, only slightly higher than velocities in the adjacent nannofossil ooze. A thin $(8 \mathrm{~cm})$ chert bed was recovered at the base of Core 5, Section 3 , but it was too brecciated by drilling to allow measurement of velocity. However, its hardness is indicated by a conchoidal fracture and vitric luster, and it probably has a much higher velocity than the adjacent silicified limestone. Measured velocities on similar cherts recovered by DSDP range from 3.3 to $5.1 \mathrm{~km} / \mathrm{sec}$ (Boyce, 1975). The reef limestones have velocities of $3.79-4.75 \mathrm{~km} / \mathrm{sec}$ and the basalts range from 3.46 to $4.32 \mathrm{~km} / \mathrm{sec}$. Acoustic impedance contrasts are high for the chalk-limestone boundary and probably are high for the chert-ooze contacts; thus these interfaces should be strong acoustic reflectors. On the other hand, there is little impedance contrast between the reef limestones and basalt, and this may explain the poor definition of the basaltic basement in seismic profiles (Figures 5 and 6).

\section{BIOSTRATIGRAPHY}

From a biostratigraphic viewpoint, the section cored at Site 384 is one of the most significant yet obtained through deep-sea drilling. The important paleontologic results of this site may be summarized as follows:

1) The section contains exceptionally rich microfaunas and floras of pelagic facies and a complete zonal succession of the lower Paleocene and Maestrichtian. These occur within a sequence of normal pelagic calcareous ooze that shows little or no evidence of dissolution of calcareous components nor any signs of depth-dependent pressure solution and reprecipitation of calcite that is a problem in thick carbonate sequences.

2) The section contains an exceptionally good sequence across the Cretaceous/Tertiary transition that is unique in its apparent completeness, excellence of 
TABLE 8

Physical Properties Data, Site 384

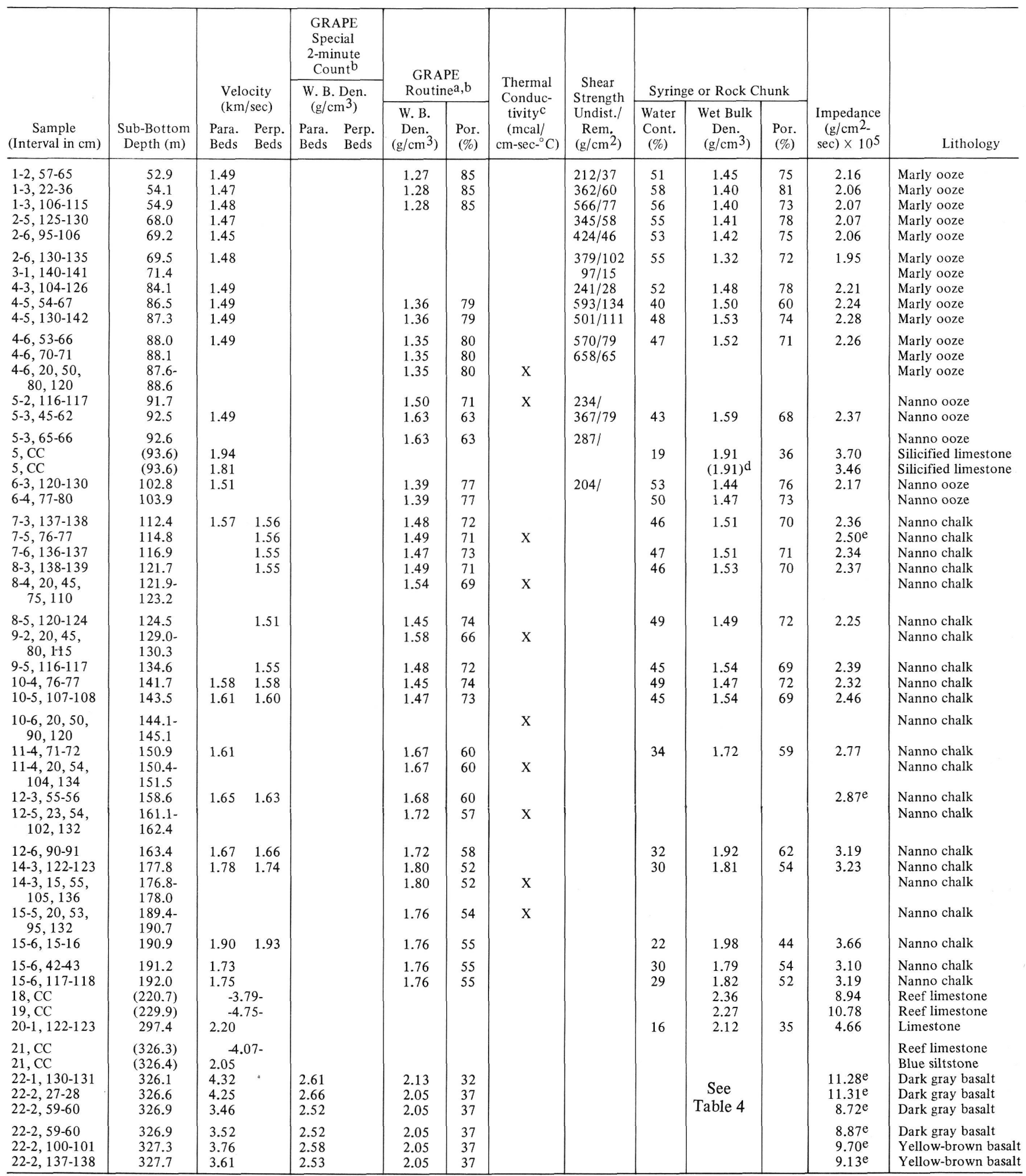

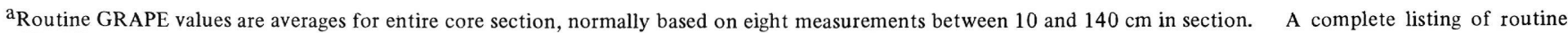
GRAPE data is given in the Appendix.

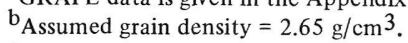

${ }^{c}$ Conductivity data not processed. Sample locations indicated by $\mathrm{X}$.

$\mathrm{d}_{\text {Assumed. }}$

${ }^{\mathrm{e}}$ Determined using GRAPE density ( 2 min. count preferred, otherwise section average). 


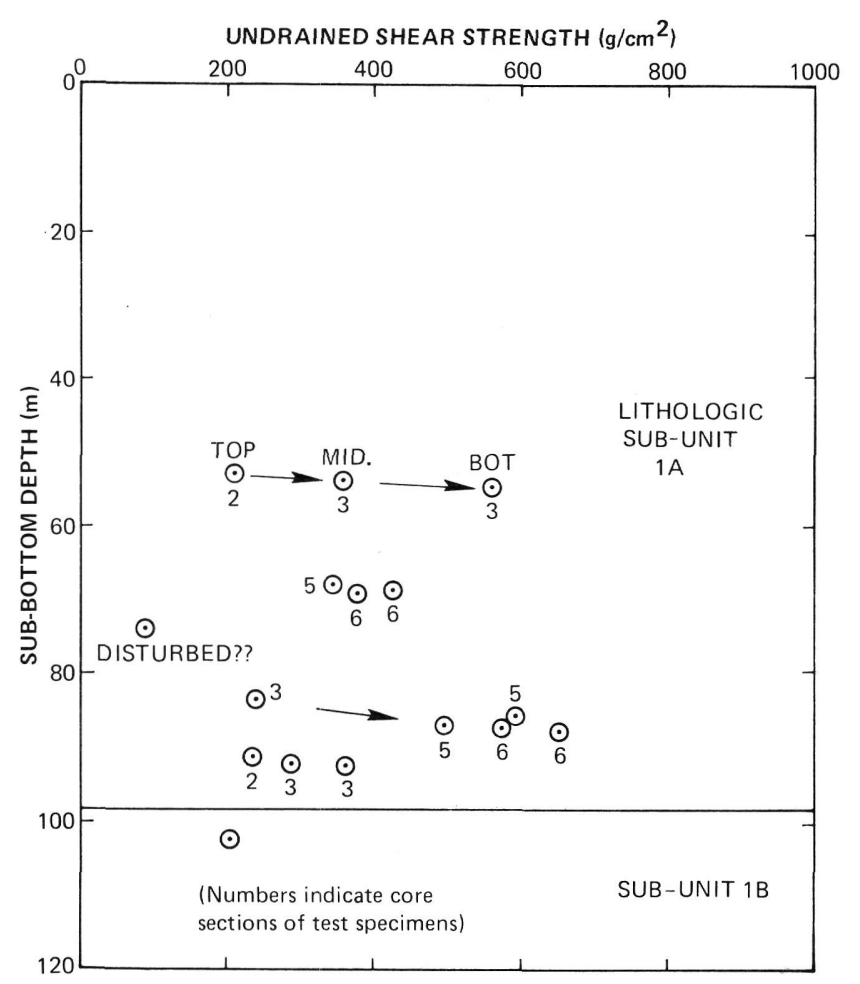

Figure 12. Shear strength data, Site 384.

preservation of calcareous fossils, and occurrence within a core rather than between cores.

3) The pelagic sequence disconformably overlies a Lower Cretaceous (Barremian-Albian) rudist-chamid reefal complex that also contains orbitolinid foraminifers and ostracodes.

4) Well-preserved siliceous microfossils (radiolarians and diatoms) occur down into the lower Paleocene, to levels equivalent to the Globorotalia angulata Zone.
They are, unfortunately, absent from the lowermost Paleocene and Maestrichtian.

\section{Cenozoic}

The first core, taken at $\mathbf{5 0 . 8}$ meters sub-bottom, contains planktonic foraminifers of the Globigerapsis kugleri Zone and nannoplankton of the Discoaster bifax Zone, already in the middle Eocene. Continuous coring below this point revealed a hiatus between lower Eocene and lower upper Paleocene, and then an apparently complete section through the lower Paleocene and into the Maestrichtian. All the planktonic foraminifer zones recognized in the section at Gubbio are present, including the "Globigerina eugubina" Zone of the lowermost Paleocene. This zone here, however, contains a richer assemblage of foraminifers than has been reported elsewhere, with the possible exception of Site 217 in the Indian Ocean. A full sequence of lower Paleocene nannoplankton zones is present as well (it should be noted that the apparent absence here of the lowermost Paleocene Markalius inversus Zone is probably a function of the excellence of preservation of nannofossils in the present section; this zone is elsewhere defined by the absence of Cruciplacolithus tenuis, which probably results from its removal by dissolution).

After completion of Site $\mathbf{3 8 4}$ it was hoped to pull the drill string up and spud a second hole for the purpose of coring the uppermost 50 meters and coring a second section across the Cretaceous/Tertiary boundary. Unfortunately, the bit was plugged tightly with altered basalt, and this objective had to be abandoned owing to lack of time and strong currents. We presume that the upper 50 meters of section include elements of the Neogene in a condensed and discontinuous sequence. Material clinging to the bit when it reached the surface contained nannoplankton of the Discoaster quinqueramus Zone (upper Miocene).

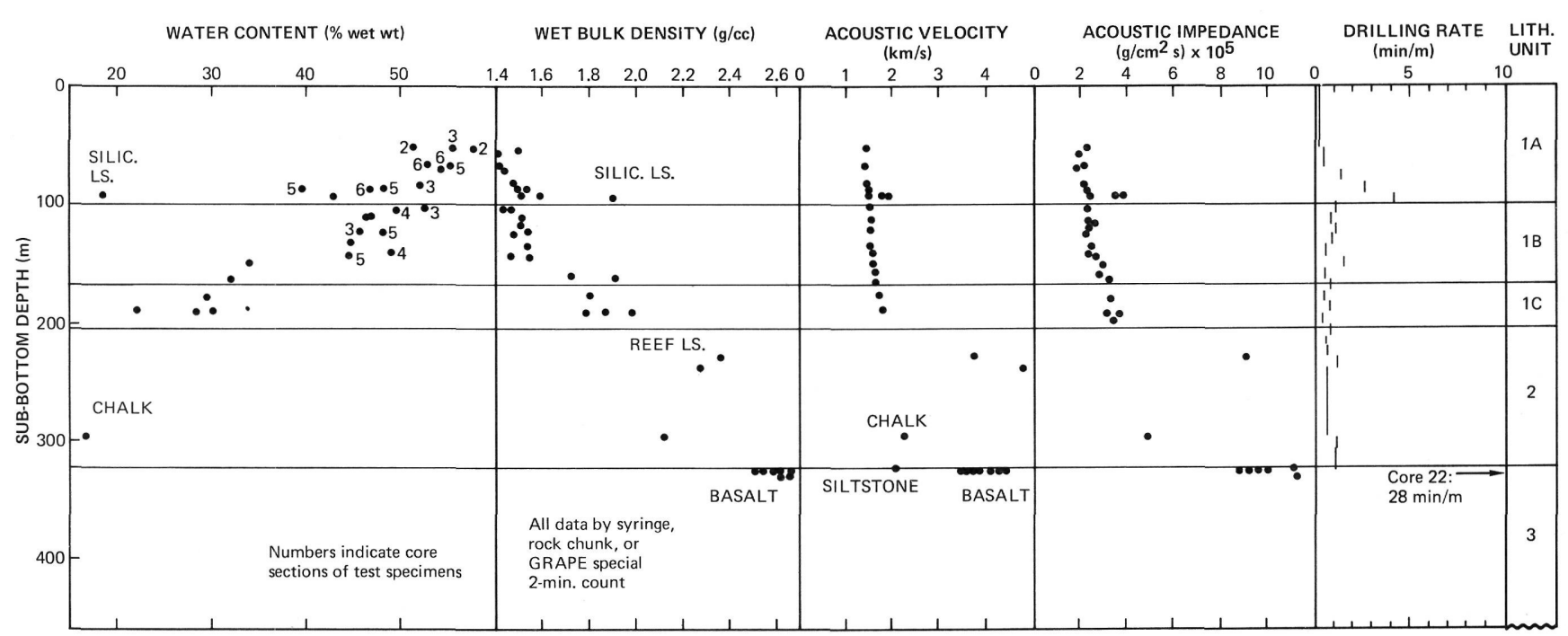

Figure 13. Physical properties data, Site 384. 


\section{Cretaceous/Tertiary Boundary}

By sampling at $10-\mathrm{cm}$ intervals across the suspect interval, the Cretaceous/Tertiary boundary was established at $33 \mathrm{~cm}$ in Section 3 of Core 13, where it also coincides with a color change from lighter tan below to slightly darker above. Bioturbation has carried Cretaceous faunal and floral elements across the contact into the Paleocene and vice versa, but the paleontologic change across the boundary is nonetheless pronounced. In addition, there is evidence of some mechanical disturbance of the contact by drilling, as indicated by angular clasts of the darker Paleocene lithology (paleontologically similar to the lowermost in-situ Paleocene) embedded in the Cretaceous to a depth of about $15 \mathrm{~cm}$ below the boundary. The slight color change is the only physical evidence for the boundary, which makes it truly remarkable in view of the drastic biological and environmental change that it signifies.

\section{Mesozoic}

Samples from below the Cretaceous/Tertiary boundary down through the core-catcher sample of Core 15 contain an apparently complete Maestrichtian succession. Cores 15 and 16 are separated by an uncored interval of 10 meters. Core 16 recovered only 1 meter of fragmental reef material along with a few lumps of medium brown clay and calcareous ooze that yielded a few recrystallized foraminifers and scarce, poorly preserved nannoplankton indicating a Coniacian/Santonian age. Because of the poor sampling in this interval, it is difficult to say where the change from shallow-water reef deposition to pelagic deposition occurs, but drilling rate data, although speculative, suggest placement in the upper few meters of the interval of Core 16.

Excepting the lumps of brown clay mentioned above, cores below Core 15 are dominated by limestones of reefal aspect, in which chamid and rudist pachydonts, associated shallow-water mollusks, corals, and larger foraminifers are abundant. The rudists are described by Perkins (this volume). No planktonic foraminifers or nannoplankton were recovered from this interval, but orbitolinid foraminifers (described by Schroeder and Cherchi, this volume) are present and are abundant in Core 21 .

The lower part of the next to last core at Site 384, Core 21, contains pieces of greenish gray, volcanogenic silty claystone (probably extremely altered basalt) underlying the reefal limestone. Neither foraminifers nor nannofossils were recovered from the claystone, but we presume it represents the basal sediments directly overlying basalt at this site.

\section{Cenozoic Foraminifers}

The outstanding achievement of coring at Site 384 was the recovery of a stratigraphically complete sequence across the Cretaceous/Tertiary boundary in a calcareous pelagic facies in which the foraminifers show few, if any, signs of dissolution. The sequence recovered here is similar to, but more complete than a section across the boundary cored during Leg 22 at Site 217 in the northern Indian Ocean. The contact at Site 384, within Section 3 of Core 13 , at $33 \mathrm{~cm}$, is marked by a subtle change from pale tan, unmottled foraminifernannofossil ooze below to slightly darker, burrowmottled nannofossil ooze or marl above. It appears that the contact has been disturbed somewhat by drilling inasmuch as subangular clasts of the Paleocene lithology have been incorporated into the uppermost Maestrichtian to a depth of about $15 \mathrm{~cm}$. The disturbance may be a result of the lithologic contrast across the contact. The Paleocene sediment was somewhat more clayey and stiffer than the Maestrichtian, which is richer in foraminifers and is thus more permeable. When Core 13 was brought on board, the interval immediately below the contact was in fact seen to be somewhat watery, and it is probable that as the drill bit was breaking through the contact, it pushed chunks of the stiffer Paleocene into the Maestrichtian, which may have been slightly softened by drilling fluid.

The faunal change across the contact involves the total or near-total elimination of the rich and diverse Maestrichtian fauna and its replacement by an impoverished assemblage that consists of two species or groups of species. Because of mixing across the boundary (probably by benthic burrowers), it is not clear whether the basal Paleocene forms are survivors of the event that caused the demise of the Cretaceous fauna, or whether they are new forms that evolved in the earliest Paleocene to fill the environmental niches vacated at the end of the Cretaceous. However, one of the basal Paleocene forms strongly resembles Hedbergella monmouthensis (Olsson), a latest Cretaceous form from which it may be derived. The other is Chiloguembelina spp., which may derive from the Cretaceous heterohelicids. The hedbergellid form is seen to give rise higher in the section to "Globorotalia" pseudobulloides (Plummer) and its various derivatives; it is already accompanied in the lowermost Paleocene by a closely related form that tends toward a globigerine apertural position and that acquires the cancellate test surface of Subbotina triloculinoides (Plummer) higher in the section.

In all, a complete and well-preserved foraminiferal section of the Paleocene up through the Globoborotalia pseudomenardii Zone was recovered; a minor interval of dissolution obliterates the contact between this zone and the underlying Globorotalia pusilla pusilla Zone. Sediments of the G. pseudomenardii Zone are disconformably overlain by the upper lower Eocene Acarinina densa Zone, which is in depositional continuity with the overlying middle Eocene Hantkenina aragonensis and Globigerapsis kugleri zones.

\section{Mesozoic Foraminifers}

The Cretaceous/Tertiary contact was recovered in Core 13 , Section 3 , at $33 \mathrm{~cm}$. It is discussed at length by Thierstein and Okada (this volume). Above the contact, burrow fillings are numerous and contain abundant specimens of the Cretaceous Abathomphalus mayaroensis Zone. It would be difficult to collect a sample from the bioturbated zone without collecting Cretaceous material as well as Tertiary. 
Samples from below the contact contain a rich fauna of the $A$. mayaroensis Zone (see distribution chart in McNulty, this volume) of the upper Maestrichtian. $A$. mayaroensis (Bolli) continues into Core 14, Section 1, $120-122 \mathrm{~cm}$, a level that is taken as the base of this zone. Globotruncana gansseri Bolli is present in the zone, suggesting that most of all of it is the lower part of the $A$. mayaroensis Zone and that the upper part may be absent.

Excepting A. mayaroensis, G. gansseri, and a few others, the ornate assemblage continues downward into Core 14. Racemiguembelina powelli Smith and Pessagno, the closely related progenitor of $R$. fructicosa (Egger), continues through Core 14, Section 3; Globotruncana contusa (Cushman) continues into Sample 14, CC, and Pseudoguembelina excolata (Cushman) into Core 15, Section 1. The lack of recovery in Sections 5 and 6 of core 14 obscures the precise base of the range of these species, the equivalent of the G. gansseri Zone, but it is evidently close to the base of Core 14, and possibly below Core 15, Section 1. As mentioned, $G$. gansseri itself does not occur in this zone, and G. aegyptiaca (Nakkady) does not appear to be present, although some rare atypical specimens are questionably assigned to it in the faunal list (McNulty, this volume). This interval of Core 14, Section 2 through Core 15, Section 1 correlates with the middle Maestrichtian. The remainder of Core 15 is correlative with the Globotruncana arca Zone (Cita and Gartner, 1971) and the lower Maestrichtian.

Core recovery was poor below Core 15 . Most of the 1.2 meters recovered for Core 16 consists of reefal limestone, including pachydont pelecypods and orbitolines. Interspersed brown claystone fragments contain severely corroded remnants of orbitolines and agglutinates (?). The orbitoline foraminifers in Core 21 are discussed separately by Schroeder and Cherchi (this volume). Cores 17 through 20 recovered only limestone fragments. However, the grains of tan calcarenite in the $70 \mathrm{~cm}$ of Core 20 include abundant orbitolines of fair preservation, poorly preserved ostracodes, and triserial and long trochospiral benthic foraminifers, too corroded for recognition as hyaline or agglutinated. Core 21 recovered greenish gray siltstone at the base that contains no foraminifers. The hole terminated with Core 22 , in basalt.

\section{Nannofossils}

The first 15 cores at Site 384 contain abundant and generally well-preserved middle Eocene to lower Maestrichtian nannofossils. These cores show continuous sedimentation throughout this period, except for the Paleocene-Eocene boundary where three nannoplankton zones are missing.

One piece of gray silt recovered from the drill bit after drilling operations were terminated contains a moderately preserved upper Miocene assemblage (Discoaster quinqueramus Zone). This sample must have originated somewhere within the uncored upper 50 meters of the sedimentary section.

The first five cores are composed of lower and middle Eocene calcareous ooze. Core 1, Section 1 through
Core 4, Section 6, $50 \mathrm{~cm}$ contain assemblages of lower middle Eocene age. Three sub-zones within the Nannotetrina fulgens Zone and the very early part of the Discoaster bifax Sub-zone are recognized in these cores. The interval between Samples 4-6, $144 \mathrm{~cm}$ and 5, CC yields upper and lower Eocene nannofossils (Discoaster lodoensis Zone and Discoaster sublodoensis Zone). The lower portion of Core 5 , assigned to the $D$. lodoensis Zone, shows extensive diagenetic recalcification, and preservation of the nannofossils is the poorest among the first 15 cores of this site.

The very top of Core 6, Section 1 contains assemblages of the upper Paleocene Campylosphaera eodela Sub-zone. Coring was continuous between Cores 5 and 6 , but the entire lower lower Eocene and possibly the top of the Paleocene are missing at this site. Below this level a complete section of the Paleocene and uppermost Cretaceous begins.

The interval between 40 and $60 \mathrm{~cm}$ in Section 1 of Core 6 yields assemblages of the Chiasmolithus bidens Sub-zone. Samples 6-1, $150 \mathrm{~cm}$ through 7-5, $60 \mathrm{~cm}$ contain assemblages of the lower Paleocene Discoaster nobilis Zone. Three zones of lower Paleocene age are recognized in Core 7, Section 6 to Core 10, Section 2. Samples from Core 10, Section 3 through Core 12, Section 2, $52 \mathrm{~cm}$ and from Samples $12-2,110 \mathrm{~cm}$ through $12-6,50 \mathrm{~cm}$ yield lower Paleocene assemblages (Ellipsolithus macellus Zone and Chiasmolithus danicus Zone). Rare occurrences of reworked Cretaceous forms are also observed. Lowermost Paleocene assemblages (Cruciplacolithus tenuis Zone) occur between Samples 12-6, $110 \mathrm{~cm}$ and $13-3,35 \mathrm{~cm}$.

The Cretaceous/Tertiary boundary was recovered in Section 3 of Core 13 and it appears to be continuous. The Maestrichtian assemblage becomes replaced by the Danian within an interval of 1 meter. Abundance and preservation of the nannoliths are remarkable throughout the transition. A complete Maestrichtian nannofossil sequence is present: upper Maestrichtian: 13-3 to 13, CC, middle Maestrichtian: 14-1 to 15-3, lower Maestrichtian: 15-4 to 15, CC. Nannoliths are abundant and well preserved throughout. High-latitude Nephrolithus frequens and low-latitude Micula mura occur together in the upper Maestrichtian interval. A few, poorly-preserved nannofossils were observed in Core 16, Section 1, the age range of which is within the Coniacian to Santonian stages. No nannofossils were found in smear slides from deeper cores.

\section{Radiolarians}

Radiolarians are abundant and well preserved at Site 384 from Core 1 (middle Eocene) down into Core 11 (upper lower Paleocene), or as far down as levels equivalent to the Globorotalia angulata foraminifer zone. They are unfortunately absent below this level. Shore-laboratory study (determinations by R. Goll) place Cores 1 through 3 in the Theocampe mongolfieri Zone of the lower middle Eocene; Core 4 down through Section 3, 70-72 cm, in the Theocotyle cryptocephala cryptocephala Zone of the upper lower Eocene; and 
Core 4, Section 4, 70-72 cm, and Core 5 in the Phormocyrtis striata striata Zone of the upper lower Eocene. Radiolarians from the underlying Paleocene sequence, which predate the lowest currently used radiolarian zone, the Bekoma bidarfensis Zone, had not been investigated at this writing, but will be significant for extending the radiolarian zonation downward and interrelating it with the foraminifer and nannoplankton zonations.

\section{Diatoms}

Well-preserved diatoms are distributed in the sediments in a pattern similar to the radiolarians. At this writing, the diatoms have not been studied.

\section{Ostracodes and Benthic Foraminifers (Frank P. van Morkhoven) ${ }^{2}$}

Sample 384-20-1, 108-110 cm, contains an interesting, if rather badly preserved fauna. Among the ostracodes, the following genera occur:
Bairdia spp. - Abundant
Cythereis spp. - Common
Centrocythere spp. - Common
Cytherelloidea spp. - Frequent
Cytherella sp. - Scarce
Cytherura sp. - Scarce

Schuleridea spp. - Scarce

Gen. indet. - Scarce

Specific determinations are difficult, if at all possible, owing to bad preservation. In general, however, this association looks rather like the Fredericksburg/ Glenrose (Aptian) associations from the Gulf Coast.

Particularly interesting, among the many species of benthic foraminifers, was the common presence of the genera Dictyoconus and Cuneolina. The former are very much like the Albian species $D$. walnutensis from Texas.

This fauna, especially Cytherelloidea and Dictyoconus, seems to indicate a very shallow, warm environment of marine deposition.

\section{SEDIMENT ACCUMULATION RATES}

At Site 384, we penetrated a middle Eocene to lower Maestrichtian sequence of deep-water pelagic calcareous ooze disconformably overlying Lower Cretaceous (Barremian to Albian) shallow water carbonates. The rate of sediment accumulation for this section is given in Figure 14. Although the upper 50 meters of section were not cored, the occurrence of middle Eocene sediments in the first core implies either that sedimentation during the late Paleogene and Neogene was very slow or that disconformities are present in the sedimentary record. Seismic reflection profiles of this region reveal varying thicknesses of acoustically non-laminated sediment above Horizon $A^{\mathrm{C}}$, suggesting that post-middleEocene bottom currents have had a strong influence on sedimentation here. If it is assumed that the high rates

\footnotetext{
${ }^{2}$ Abstracted from a written communication, 25 August, 1975.
}

of accumulation $(\sim 11 \mathrm{~m} / \mathrm{m} . \mathrm{y}$. $)$ that characterize the middle Eocene interval reflect sedimentation during the remainder of the Tertiary, then considerable volumes of sediment must have bypassed or been eroded from the area of Site 384, probably as a result of intensified abyssal circulation.

Because of spotty sampling, the sedimentation history of the Lower Cretaceous carbonates is less precisely known than that of the overlying oozes. They do, however, indicate accumulation at a net rate of about $15 \mathrm{~m} / \mathrm{m} . \mathrm{y}$. The contact between these shallowwater carbonates and the overlying sediments was not cored, but the two units are most likely disconformable, suggesting that sedimentation during Cenomanian through Campanian time was nil (with the exception of the recovery of nannofossils of Coniacian/Santonian affinity in Core 16). Probably not coincidentally, this gap in the sedimentary record marks a drastic change in depositional environment from very shallow water (back-reef) sedimentation to typically deep marine (bathyal) pelagic sedimentation, and may be representative of the subsidence of $J$-Anomaly Ridge through near-surface higher velocity currents before reaching depths at which lower current velocities would allow sediments to accumulate.

Probably the most interesting aspect of the accumulation rate curve is the interval that spans the Cretaceous/ Tertiary contact. Although further revisions in absolute ages within this interval may modify the pattern somewhat, there seems to be a trend from moderately fast accumulation $(\sim 10 \mathrm{~m} / \mathrm{m} . \mathrm{y}$.$) in the early and mid-$ Maestrichtian to relatively low rates $(\sim 6 \mathrm{~m} / \mathrm{m} . \mathrm{y}$.) in the late Maestrichtian to early Paleocene, with a return to rates typical of or even on the high side of calcareous pelagic ooze deposition (about $20 \mathrm{~m} / \mathrm{m}$.y.) in the mid Paleocene. The drop-off in accumulation rate in the late Maestrichtian-early Paleocene may reflect lowered biological productivity during this time as a result of lowered taxonomic diversity and numerical abundance of plankton marking the end-Cretaceous extinctions. The sediment accumulation curve suggests that no hiatus is present at the Cretaceous/Tertiary contact or that if one is present, it is of very short duration.

The sediment accumulation curve indicates a significant hiatus separating upper Paleocene from upper lower Eocene sediments. A gap of some $10 \mathrm{~m} . \mathrm{y}$. is indicated, and although a hiatus is undoubtedly present (as indicated by missing biostratigraphic zones), its duration is probably less than indicated owing to the revised Paleocene time scale employed here (see Discussion under Biostratigraphy in the introductory chapter of this volume). The geological significance of this hiatus is not clear. The decrease in drilling rate and the occurrence of porcelanites at this level indicate that Horizon $A^{c}$ immediately overlies the hiatus. It is not presently possible to say, however, whether there is a casual relationship between this period of erosion/non-deposition and formation of the porcelanites. 


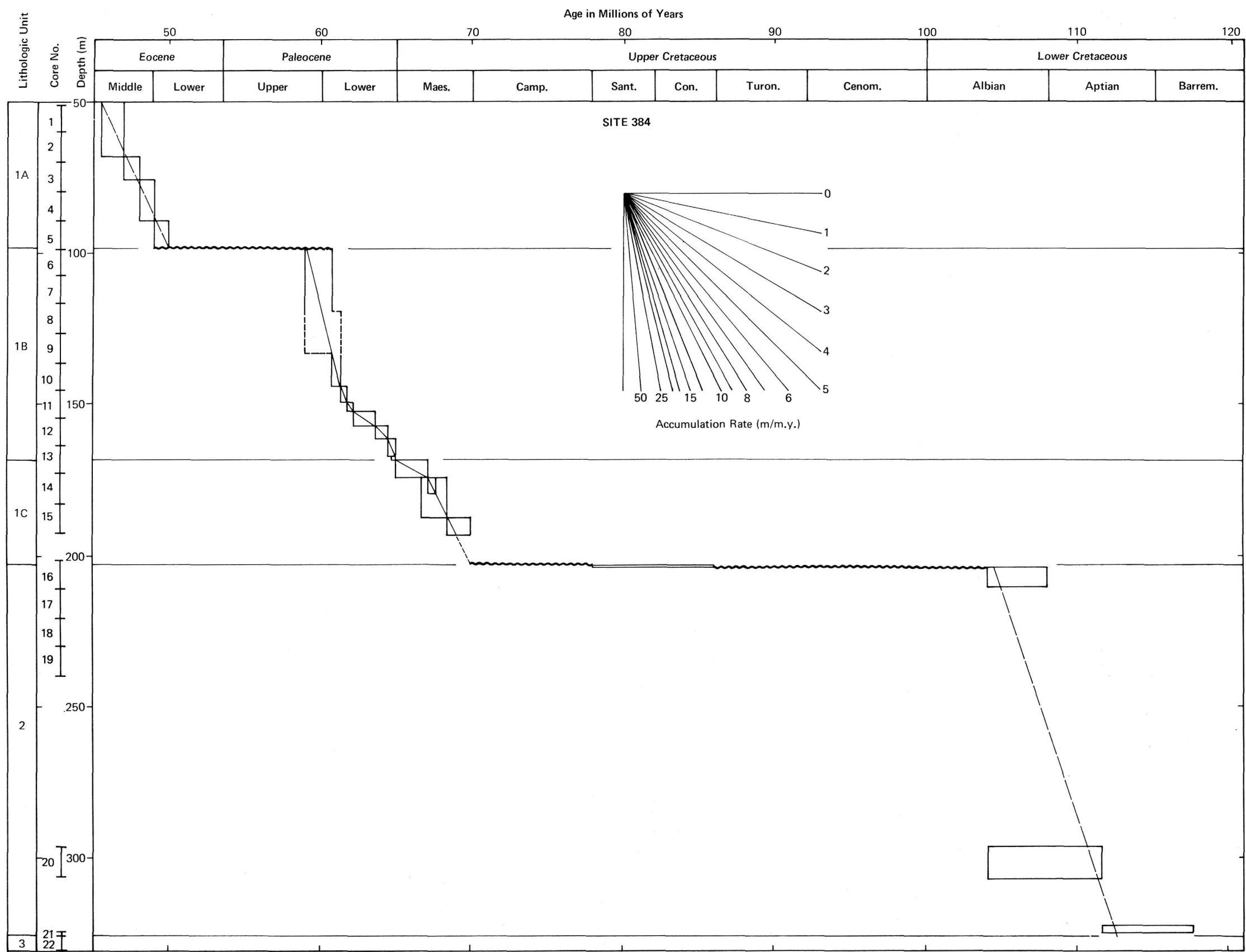




\section{CORRELATION OF SEISMIC PROFILE WITH DRILLING RESULTS}

The basement high comprising the $J$-Anomaly Ridge extends along a northeast trend from Site $\mathbf{3 8 3}$ into the continental rise south of the Grand Banks and intersects the Southeast Newfoundland Ridge near $41^{\circ} 30^{\prime} \mathrm{N}$, $48^{\circ} 30^{\prime} \mathrm{W}$ (Figures 1, 2). In the region near Site 383, the ridge has a west-facing escarpment with a relief of 500 to 1000 meters. The ridge shoals gradually northward and then rises abruptly near $40^{\circ} \mathrm{N}$ (Figure 1 ). Where the ridge emerges above the thick sedimentary cover near the continental margin, specifically west of Site 384, the height of the west-facing basement escarpment increases to more than 1800 meters.

Relatively smooth acoustic basement is observed along the $J$-Anomaly Ridge crest between Sites 383 and 384, and Lynch profiles show that the smooth acoustic basement extends at least $100 \mathrm{~km}$ northeast of Site 384 .

The Vema 2801 reference profile used to select Site 384 (Figure 3) shows the smooth, southeast-dipping basement of the ridge and the northwest facing scarp, and serves to illustrate the regional acoustic stratigraphy. From top to bottom the acoustic section on the J-Anomaly Ridge consists of (1) acoustically nonlaminated sediments which blanket the ridge and which are unconformable with deeper structure; (2) a prominent reflector or reflector series which lies at 0 to $0.3 \mathrm{sec}$ above basement and which is conformable with neither basement nor with the sea floor. This reflector has an acoustic character and stratigraphic position similar to that of Horizon $A^{c}$ (Tucholke, this volume), but it has not been correlated in profiler records across the intervening Sohm Abyssal Plain to known occurrences of the reflector on the northern Bermuda Rise. (3) an acoustically nonlaminated to weakly laminated interval between Horizon $A^{\mathrm{c}}$ and acoustic basement.

Under the adjacent continental rise and Sohm Abyssal Plain the acoustic section contains (1) regular acoustic laminae probably representing turbidites or contourites and synchronous with or post-dating acoustic interval 1 on the $J$-Anomaly Ridge; (2) acoustically nonlaminated and weakly laminated sediments overlying acoustic basement (mostly unconformably) and possibly synchronous with acoustic intervals 1-3 on the ridge.

Interval 1 on the $J$-Anomaly Ridge resembles many current-deposited sediment drifts which postdate the Paleogene initiation of strong abyssal circulation in the North American Basin. However, because there are no internal reflectors to define former depositional surfaces, the interval could be a sedimentary layer deposited conformably and subsequently sculpted by bottom currents.

The drilling objectives at Site 384 included several acoustic-stratigraphic problems in addition to the primary objective of coring and dating basaltic crust. They were to determine the nature and depositional processes of the upper, nonlaminated sediments, to sample and date the strong reflector locally developed along the ridge and determine whether it correlated with Horizon
$A^{C}$, and to determine the nature of the unusually smooth acoustic basement developed along the $J$-Anomaly Ridge.

Only one EDO recorder was functioning during our brief presite survey, and it was producing a "grassy" record of marginal quality (Figure 5). The Challenger record shows a thin $(<0.2 \mathrm{sec})$ nonlaminated sediment cover on the ridge crest near Site 384, overlying a poorly defined mid-sediment reflector and acoustic basement. Site 384 was drilled at a location where these acoustic sequences seemed best defined, northwest of the ridge crest.

The EDO recorders were repaired during the drilling operations, and an extensive series of on-site profiler records were obtained using a variety of frequency band passes, airgun depths, and airgun combinations (10 and 40 in. ${ }^{3}$ ). With due care taken to identify side echoes, these tests helped confirm the depth of major reflectors at the site and allowed selection of the optimum recording configuration for our postsite survey (Figures 4, 6).

After the drill string was pulled at Site 384 , we steamed west across the site, missing the beacon position by about 300 meters. The $40-160 \mathrm{~Hz}$ profiler record and its interpretation are shown in Figure 6.

\section{Correlation With Drilling Results}

Figure 15 shows the correlation between the drilling record and profiler record at Site 384 . Because of the marginal quality of the approach record, the reflector depths and attitudes are best estimates based on combined interpretation of the approach record, the on-site record, and the post-site survey.

The upper, acoustically nonlaminated layer (about $0.12 \mathrm{sec}$ thick) correlates with the marly nannofossil oozes and nannofossil oozes cored down to about 96-97 meters sub-bottom, where chert and silicified limestone were encountered. Core 5 bottomed at 98.6 meters, and the core catcher was jammed with a piece of silicified limestone; this probably explains the low core recovery $(48 \%)$. The driller's interpretation of hard layers cored in Core 5 and the recovery of minor chert/silicified limestone in the core both suggest that the in-situ bed occurs over a narrow depth interval $(<8 \mathrm{~m})$ as a series of thin layers interbedded with nannofossil ooze. This agrees with data from the on-site profiler tests, which show that the horizon is less reflective for longer wavelength, lower frequency signals. The chert and silicified limestone in Core 5 provide the only pronounced velocity/impedance variation in the nannofossil ooze-chalk section, which extends down to about 200 meters (Figure 16). The cherts correlate closely both in age (upper lower Eocene) and in composition with Horizon $A^{c}$ as identified on DSDP Legs 1 and 2 elsewhere in the western North Atlantic away from the continental margin (Ewing et al., 1970). The calculated interval velocity in the nannofossil ooze section above Horizon $A^{C}$ is $1.62 \mathrm{~km} / \mathrm{sec}$ (Figure 15).

A reflector near $0.24 \mathrm{sec}$ sub-bottom correlates with the top of the shallow-water bioclastic limestones recovered in Core $16(202.2-211.4 \mathrm{~m})$ and indicates an interval velocity for the nannofossil chalks and 


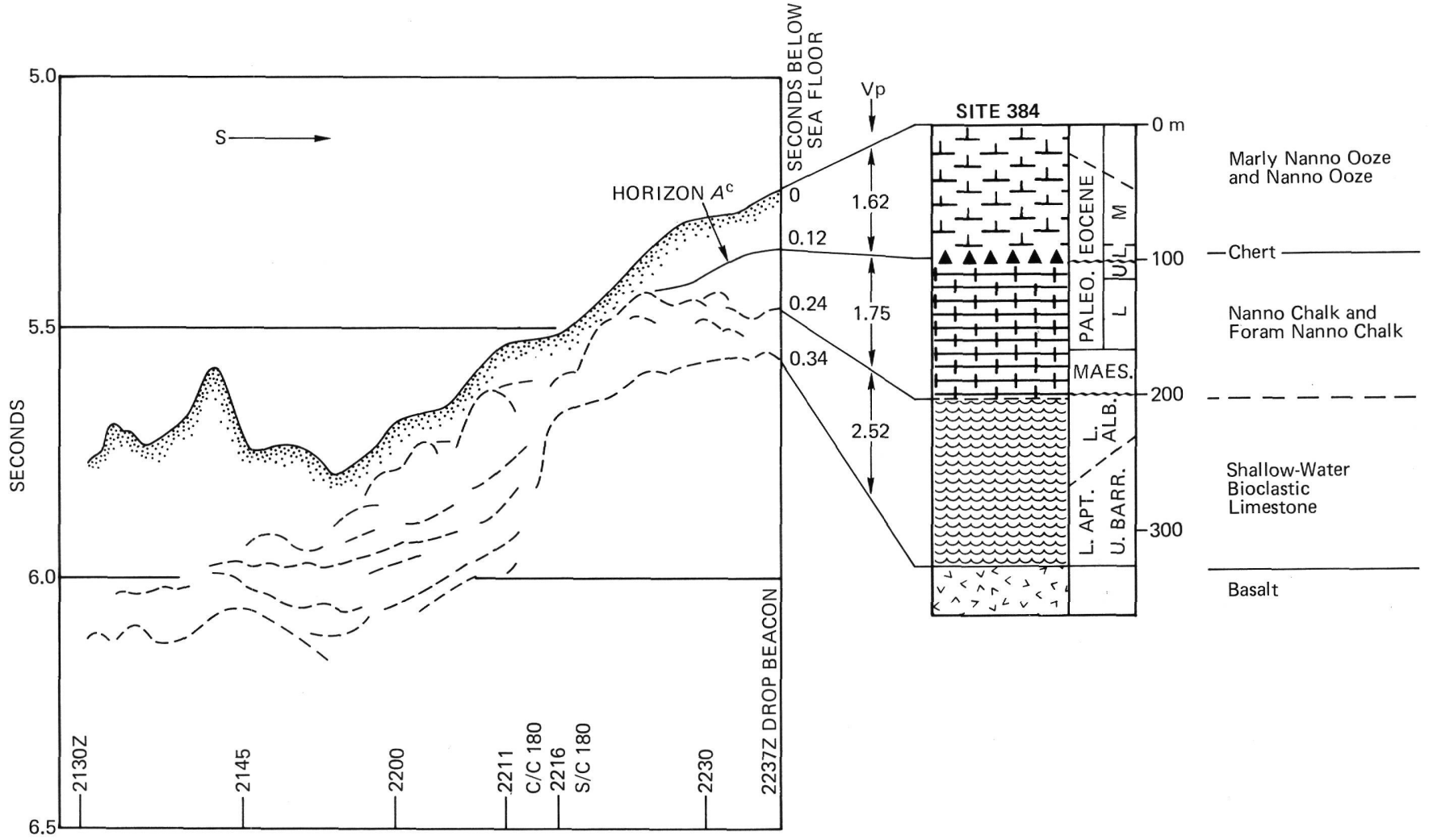

Figure 15. Correlation between Glomar Challenger approach profile and the lithologic section at Site 384.

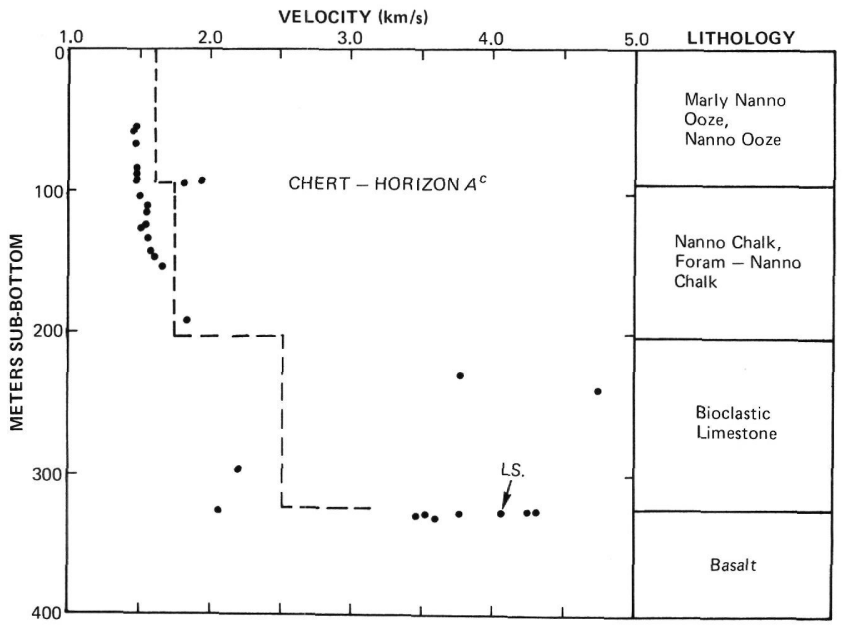

Figure 16. Sonic velocities in the section at Site 384 measured directly with the Hamilton Frame velocimeter (dots) and interval velocities calculated from correlation with seismic profile (dashes) at Site 384.

foraminifer-nannofossil chalks below Horizon $A^{C}$ of about $1.75 \mathrm{~km} / \mathrm{sec}$ (Figure 15). Measured velocities show a prominent velocity gradient in the lower part of these chalks; if this increase is stepwise rather than linear, it may explain the acoustic "haze" and weak acoustic laminae developed between Horizon $A^{c}$ and the bioclastic limestone reflector (Figure 5). Furthermore, the approach of velocities in the deepest chalk to probable velocities in the uppermost bioclastic limestones suggests a minimal impedance contrast at the boundary; this may partially explain the weak, diffuse character of the reflector at this lithofacies change.

There may be only a slight impedance contrast between the deepest bioclastic limestones and basalt, although two measured velocities on samples within 20 meters of basalt do not support this inference (Figure 16). The echo from the probable depth of basalt is weak and its identification is speculative (Figures 5 and 15). The broad interval of higher amplitude returns which first appears about $0.34 \mathrm{sec}$ sub-bottom at Site 384 is interpreted as basaltic basement. The calculated interval velocity of $2.52 \mathrm{~km} / \mathrm{sec}$ for the bioclastic limestones seems low compared to two velocities measured directly on samples from the upper part of the bioclastic section. However, the Hamilton Frame velocities were measured only on large, well-lithified pieces of limestones; low core recovery consisting mostly of limestone of sand, gravel, and cobble size suggests that most of the interval contains low velocity, poorly cemented or uncemented bioclastic limestones. Thus the calculated interval velocity of $2.52 \mathrm{~km} / \mathrm{sec}$ is reasonable.

Measured velocities on pieces of basalt with varying degrees of alteration ranged from 3.46 to $4.32 \mathrm{~km} / \mathrm{sec}$. There is little impedance contrast between the basalts and the shallower bioclastic limestones, but there is a significant impedance contrast between basalt and the overlying minor chalk and siltstone. 


\section{Implications for Geologic History}

The foregoing lithologic/acoustic correlations applied to the Challenger profile departing Site $\mathbf{3 8 4}$ have several interesting implications regarding the geologic development of the shallower part of the $J$-Anomaly Ridge (Figure 6).

The bioclastic limestones form a relatively flat cap over basaltic basement of poorly known acoustic character. In the Challenger reflection record there is a suggestion of possible reefal fronts and deeper lagoonal basins developed in the limestones. That at least portions of this reef were subjected to supratidal weathering (see Lithologic Summary) indicates that much of the original reef morphology may have been altered or destroyed.

The acoustically opaque reef flanks may be either relatively solid limestone or a carbonate talus slope (Figure 6). In the former case the fact that we can trace this acoustic section down to about $5.9 \mathrm{sec}$ suggests that the ridge has subsided at least 4600 meters since the demise of the reef in the Albian.

The thickness distribution of the chalk unit between the reefal limestones and Horizon $A^{C}$ is like that expected in an environment of normal pelagic sedimentation. The unit tends to be thick on the gentle slopes, and thinner on steeper slopes where the sea-floor gradient probably exceeded the angle of repose for the calcareous oozes.

The strong reflectivity of Horizon $A^{C}$ (chert) and its close approach to acoustic basement (i.e., to the reefal limestones at Site 384 and possibly to basalt on the deeper reaches of the $J$-Anomaly Ridge) suggest that smooth acoustic basement on the deeper part of the $J$-Anomaly Ridge actually may be Horizon $A^{C}$ masking a slightly deeper and rougher basaltic surface. The reefal limestones also create a moderately smooth acoustic basement, but with the available profiler data we cannot determine the seaward extent of these limestones on the southwest-plunging ridge.

The distribution of irregularly sculpted sediments above the relatively smooth Horizon $A^{c}$ (Figure 6) shows that bottom currents have had a significant effect on the sedimentary record since middle Eocene time. Recovery of middle Eocene sediment at only 50 meters sub-bottom at Site 384 implies that the interval between the sea floor and Horizon $A^{c}$ contains mostly Paleogene sediment; however, upper Miocene sediment was recovered from the bit when the drill string was pulled, and Piper (1975) has reported that a piston core taken about $19 \mathrm{~km}$ east of Site 384 on the $J$-Anomaly Ridge contains Plio-Pleistocene nannofossil-foraminifer ooze. If Neogene deposits are an important component of the sedimentary section above Horizon $A^{c}$, then the section either must have accumulated at extremely slow rates or must be interrupted by one or more disconformities. Because of the rapid Eocene sedimentation rates determined at Site 384 and the probable activity of bottom currents after middle Eocene time, the presence of hiatuses in the sedimentary record provides the better explanation.

\section{SUMMARY AND CONCLUSIONS}

Site 384 was drilled to a total depth of 330.3 meters, penetrating 324.8 meters of sediment and recovering 2.35 meters of basalt that is believed to be the top of the volcanic basement originally formed at the axis of the Barremian/Aptian Mid-Atlantic Ridge (Figure 7). The principal objective of this site was to sample the igneous basement in order to investigate the cause of the exceptionally high-amplitude $J$-Anomaly and to determine whether the associated ridge is compositionally anomalous, perhaps like similarly elevated ocean crust around Iceland and the Azores.

Additional objectives included (a) dating the sediment immediately above the basement, thus constraining the age of the young end of the Keathley Sequence ( $M$-series) magnetic lineations; (b) identifying the lithofacies responsible for the prominent intrasediment acoustic reflector (Horizon $A^{c}$ ?) seen on Vema, Lynch, and Challenger reflection profiles; and (c) to sample possible calcareous microfossil assemblages generally not preserved in deeper areas of the western North Atlantic.

A total of 22 cores was attempted, representing 59 per cent of the depth drilled, and 110.5 meters $(57 \%)$ of core were recovered. Despite marginal operating conditions-a combination of strong Gulf Stream currents and 30 to $40 \mathrm{mph}$ winds-the major objectives were met. Several discoveries of major scientific significance were made at Site 384 , although only a short time ( 2.25 days) was spent on station.

Upon analysis by shore laboratories, the basalt recovered at Site 384 proved to be a tholeiite only slightly enriched in LIL elements and of undistinguished magnetization. However, Site 384 was drilled on Keathley anomaly $M-2$, and post-cruise analysis of magnetic profiles suggests that the main mass of anomalous magnetization lies just to the east between anomalies $M-1$ and $M-0$ (Rabinowitz et al., this volume). Thus the lack of unusual magnetization or of enrichment of $\mathrm{FeO}$ and $\mathrm{TiO}_{2}$ in the basalt is not unexpected. The basalt shows effects of low-temperature alteration, as anticipated. Perhaps more importantly, the lower basalt shows evidence for high-temperature deuteric alteration which is rare in ocean floor basalts but typical of subaerial extrusion. Magnetic properties of the basalt also are more characteristic of subaerial extrusion (Petersen et al., this volume). The presence of erosional basaltic debris within a "soil" immediately overlying the basalt also provides further tentative evidence that the $J$-Anomaly Ridge was emergent early in its history.

Three independent basement age determinations were possible at Site 384: (1) radiometric age determinations on the basalt (Houghton et al., this volume), (2) paleontological age determinations of rudists recovered from the bioclastic limestone above the basalt, and (3) paleontological age determination of orbitoline foraminifers also recovered from the bioclastic limestone (Schroeder and Cherchi, this volume). Two radiometric ages were obtained for basalt at Site 384 
(Houghton et al., this volume). A value of $88 \pm 5 \mathrm{~m} . \mathrm{y}$. from whole-rock ${ }^{40} \mathrm{Ar} /{ }^{39} \mathrm{Ar}$ dating is not very reliable because the apparent age versus incremental temperature curve is rather irregular. Another basalt fragment, chosen for its lack of amygdaloidal chlorite, gave a K-Ar whole-rock age of $106 \pm 4$ m.y. Because both ages are likely to be lower limits, we infer a minimum absolute age of $106 \pm 4 \mathrm{~m} . \mathrm{y}$. for the basalt. Of the rudists in the overlying bioclastic limestones, specific identifications were not possible on the fragments in Core 16, but Perkins (this volume) notes that the general form of the steinkerns resembles lower Albian forms in central Texas and northern Mexico. Rudists from Core 20 indicate an age from middle Aptian through Albian but probably not older than Albian. In the underlying Core 21, Schroeder and Cherchi (this volume) identified orbitolinid fauna characteristic of the upper Barremian-lowermost Aptian. Thus the bioclastic limestones appear to represent a sequence ranging from upper Barremian/lower Aptian at the base up through the lower Albian. On the van Hinte (1976) time scale, this places a minimum basement age of $113-118$ m.y. on anomaly $M-2$ and the $J$-Anomaly Ridge. Because the ridge may have been subaerially exposed during its early history, we are uncertain of the elapsed time between the cessation of basalt extrusion and initial deposition of bioclastic debris. Reasonable erosion and subsidence rates suggest that the time increment is unlikely to be more than a few million years.

A 123-meter thick section of bioclastic limestone, probably late Barremian to early Albian in age, overlies the basalt. This unexpected lithofacies, displaying such features as micritization rims, dolomitization, and moldic porosity, indicates that the $J$-Anomaly Ridge was close to and temporarily even above sea level for the first few million years of its existence (Rothe, this volume). Magnetic properties and high vesicularity of the basalt, as well as high $\delta^{18} \mathrm{O}$ values probably resulting from fresh-water diagenesis of the carbonates, reinforce this conclusion. Deposition probably occurred in a shallow bank environment with scattered biostromes and intervening quiet water. Limestone composition and morphology of the limestone surface near Site 384 are consistent with deposition in a back-reef environment. At a depth of 4235 meters below sea level, the top of the basalt at Site 384 represents the most deeply subsided former sea-level basement surface yet penetrated by the Challenger's drill string; by comparison, the guyots of the Mid-Pacific Mountains have subsided half this amount at most.

Perhaps the most significant achievement at Site 384 was the first recovery in the open ocean of an apparently continuous stratigraphic sequence across the Cretaceous/ Tertiary boundary containing well-preserved calcareous microfossils. The section appears to be continuous from the lower Maestrichtian up through the middle Eocene, except for a hiatus of perhaps 10 m.y. in the uppermost Paleocene and lower half of the lower Eocene. The lower Danian foraminifer Zone P1 is present directly above the upper Maestrichtian.
Foraminifers equivalent in age to the "Globigerina" eugubina Zone are present in the lowermost Danian. The lowermost Danian nannofossil zone, NP 1, is not observed. However, as pointed out by Thierstein and Okada (this volume), NP 1 has been defined as the interval between the extinction of the Cretaceous taxa and the lowermost occurrence of Cruciplacolithus tenuis, and it is very likely that the absence of the fragile $C$. tenuis (and the presence of NP 1) is merely a preservational artifact at most sections studied. Thus, in the excellently preserved section at Site 384, the "absence" of NP 1 may have no bearing on the continuity of the sedimentary record.

Sharpness of the Danian/Maestrichtian contact could indicate that a short hiatus is present. Paleontological and paleomagnetic data put an upper limit of about $5 \times 10^{5}$ years on any hiatus. The lack of evidence for any dissolution at the boundary also refutes the hypothesis that an extreme rise in the CCD was responsible for the end-Cretaceous extinctions, inasmuch as the extinction level in the borehole was probably at least 2300 to 3100 meters below sea level at that time (see Tucholke and Vogt, this volume). Oxygen isotope analyses (Boersma et al., this volume) suggest that both surface and bottom water temperatures rose several degrees across the Cretaceous/Tertiary boundary. Lithologically, the boundary marks a time of gradually decreasing $\mathrm{CaCO}_{3}$ content and increasing clay deposition. There is also a significant increase in the abundance of montmorillonite and clinoptilolite at this level. Because both of these minerals can be formed by devitrification of volcanic ash, an increase in volcanic activity may have occurred at the base of the Tertiary.

Prior to Leg 43 it was not known if the paleooceanographic conditions that led to the widespread formation of chert over much of the western North Atlantic extended north of the New England seamounts. This uncertainty was based on the observation that the seismic reflector Horizon $A^{C}$, which correlates with cherty lithofacies at many drill sites, is difficult to trace north of the seamounts because of the thick, reflective turbidite cover of the Sohm Abyssal Plain. At Site 384 (and Site 385 on the north flank of Vogel Seamount), the recovery of upper lower Eocene chert at the level of a prominent mid-sediment reflector demonstrates that both the chert-forming conditions and Horizon $A^{C}$ extend northeast of the seamounts. Whether the cherty facies and corresponding reflector are continuous beneath the Sohm Abyssal Plain, however, remains to be tested with improved seismic techniques and further drilling.

Several hiatuses are defined or suggested in the Site 384 section. The lowermost spans some 20 million years in Core 16 between the Aptian/Albian bioclastic limestones and overlying Coniacian/Santonian ooze. During the early Late Cretaceous while the bioclastic limestones were subsiding from sea level, they may have been kept free of sediment cover by near-surface currents. Later carbonate deposition, at least during the Campanian, probably was attenuated or prevented by a CCD level shallower than the crest of the $J$-Anomaly 
Ridge (see Tucholke and Vogt, this volume). Hiatuses of similar age and duration also have been observed at Holes 390 and 392A on the Blake Nose (Benson, Sheridan, et al., 1976).

Beginning probably in the early Maestrichtian, a more or less continuous pelagic carbonate sequence began to accumulate on the $J$-Anomaly Ridge. At Site 384 , a $\sim 9$ m.y. hiatus was encountered in the lower Eocene section just below the Horizon $A^{c}$ cherts. Recovery of middle Eocene oozes in Core 1 at only 50 meters sub-bottom also indicates that the late Paleogene and Neogene sequence is either strongly condensed or is interrupted by one or more hiatuses. The latter interpretation is supported by seismic profiles, which show that the sedimentary sequence on the ridge has been sculpted by the Western Boundary Undercurrent, probably beginning after middle to late Eocene time.

\section{REFERENCES}

Benson, W. E., Sheridan, R. E., et al., 1976. In the North Atlantic: Deep-Sea Drilling, Geotimes, v. 21, p. 23-26.

Boyce, R. E., 1975. Physical properties. In Jackson, E. D., Schlanger, S. O., et al., Initial Reports of the Deep Sea Drilling Project, v. 33: Washington (U.S. Government Printing Office), p. 931-958.

Cita, M. B. and Gartner, S., 1971. Deep sea Upper Cretaceous from the western North Atlantic, Second Int. Plankt. Conf., Proceedings: Leiden (E. J. Brill), p. 287-319.
Ewing, J. I., Windisch, C., and Ewing, M., 1970. Correlation of Horizon A with JOIDES borehole results, J. Geophys. Res., v. 75, p. 5645-5653.

Folk, R. L., 1959. Practical petrographic classification of limestones, Am. Assoc. Petrol. Geol. Bull., v. 43, p. 1-38. 1962. Spectral subdivision of limestone types. In Ham, W. E. (Ed.), Classification of carbonate rocks: Am. Assoc. Petrol. Geol., Mem. 1, p. 62-84.

Ginsburg, R. N., 1956. Environmental relationships of grain size and constituent particles in some south Florida carbonate sediments, Am. Assoc. Petrol. Geol. Bull., v. 40, p. 2384-2427.

Müller, G. and Gastner, M., 1971. The “'Karbonat-Bombe,” a simple device for the determination of the carbonate content in sediments, soils, and other materials, $N$. $J b$. Mineral., Mh., v. 10, p. 466-469.

Piper, D. J. W., 1975. Upper Cenozoic glacial history south of Grand Banks of Newfoundland, Canadian J. Earth Sci., v. 12, p. 503-508.

Vail, P. R., Mitchum, R. M., Jr., and Thompson, S., III, 1977. Global cycles of relative changes of sea level. In Payton, C. E. (Ed.), Seismic Stratigraphy - Applications to Hydrocarbon Exploration: Am. Assoc. Petrol. Geol. Mem. 26, p. 83-97.

van Hinte, J. E., 1976. A Cretaceous time scale, Am. Assoc. Petrol. Geol. Bull., v. 60, p. 498-516.

Worsley, T. R., 1974. The Cretaceous-Tertiary boundary event in the ocean. In Hay, W. W. (Ed.), Studies in Paleooceanography: Soc. Econ. Mineral. Paleontol. Spec. Publ., v. 20, p. 94-125.

Zimmerman, H. B., 1972. Sediments of the New England continental rise, Geol. Soc. Am. Bull., v. 83, p. 3709-3724. 

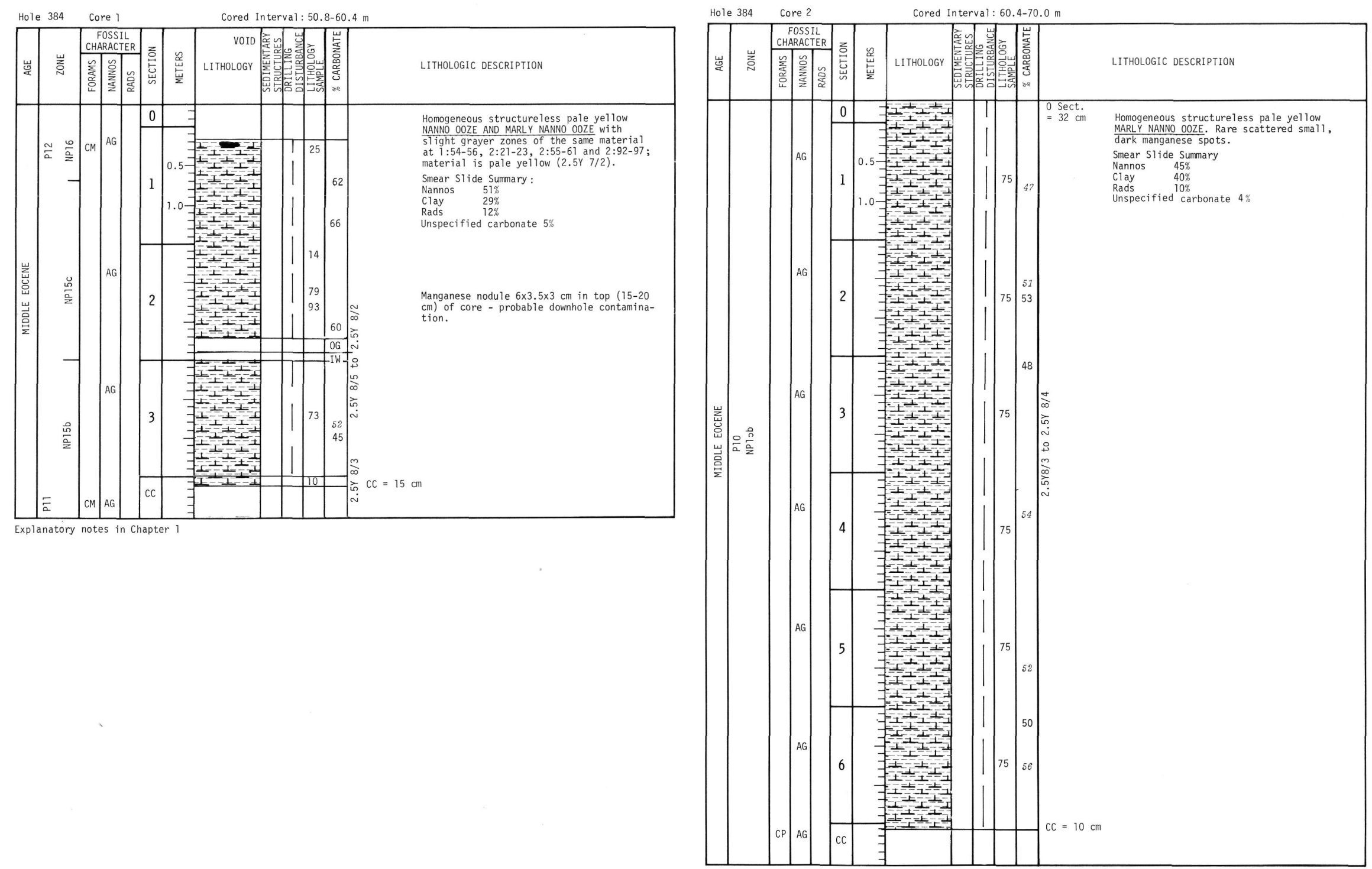

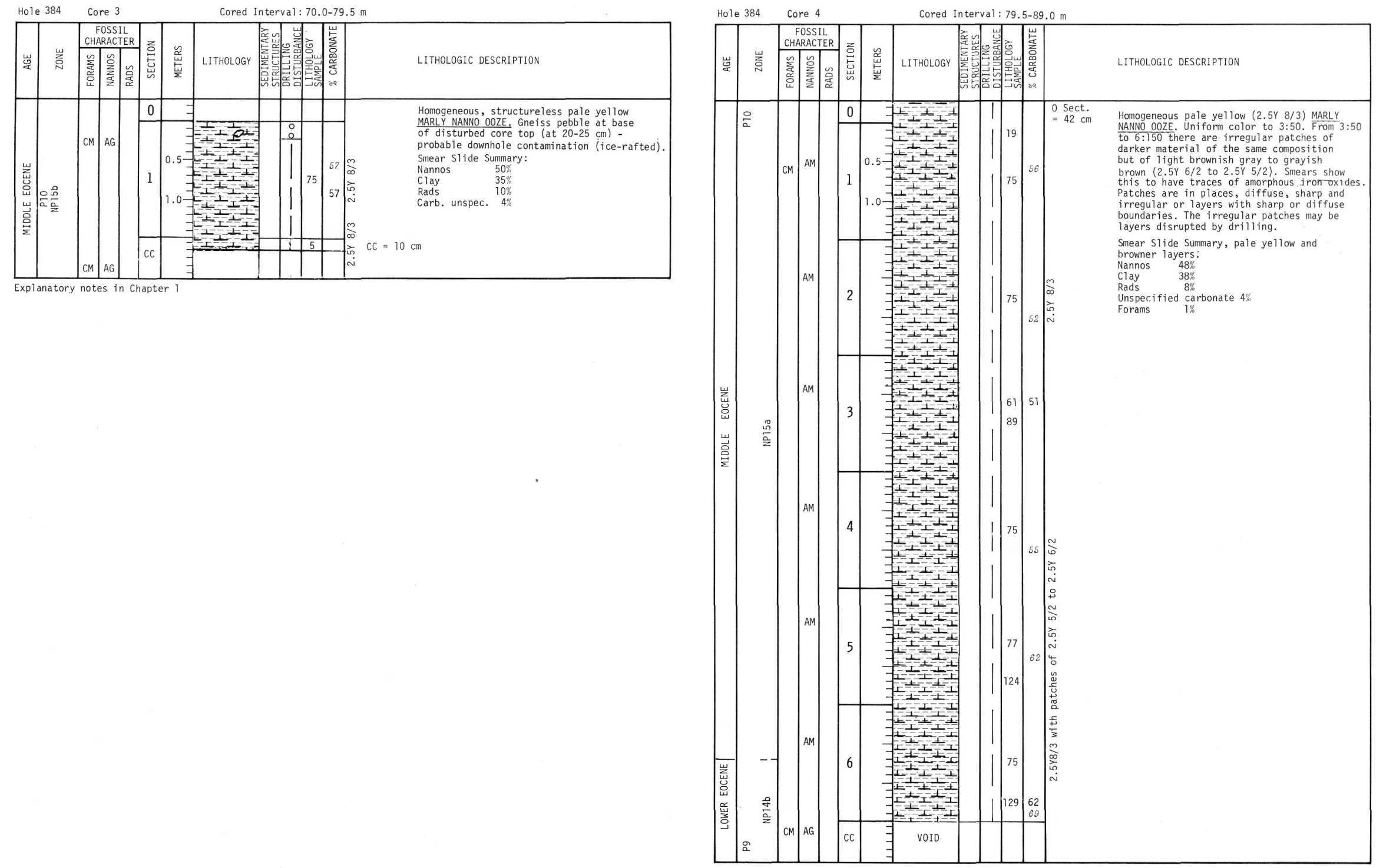

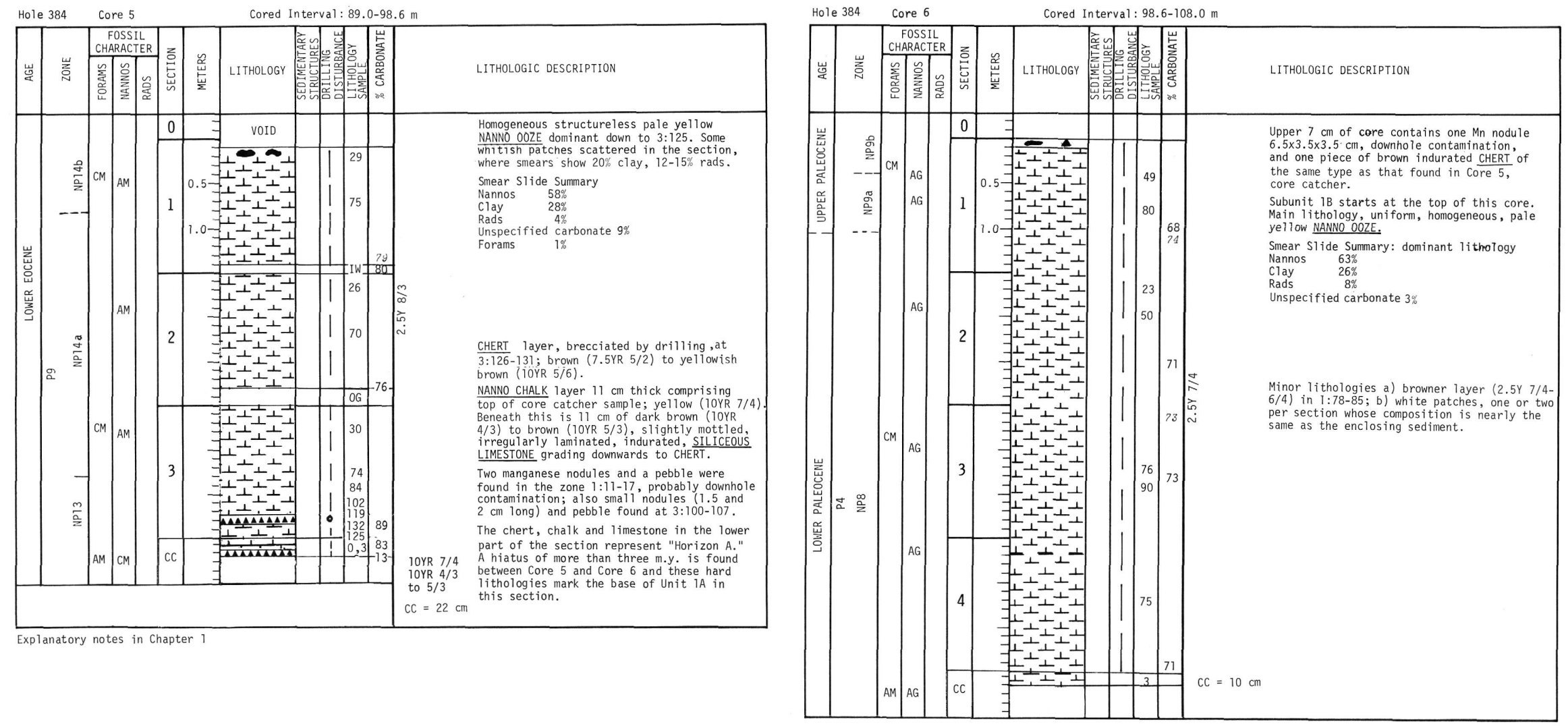

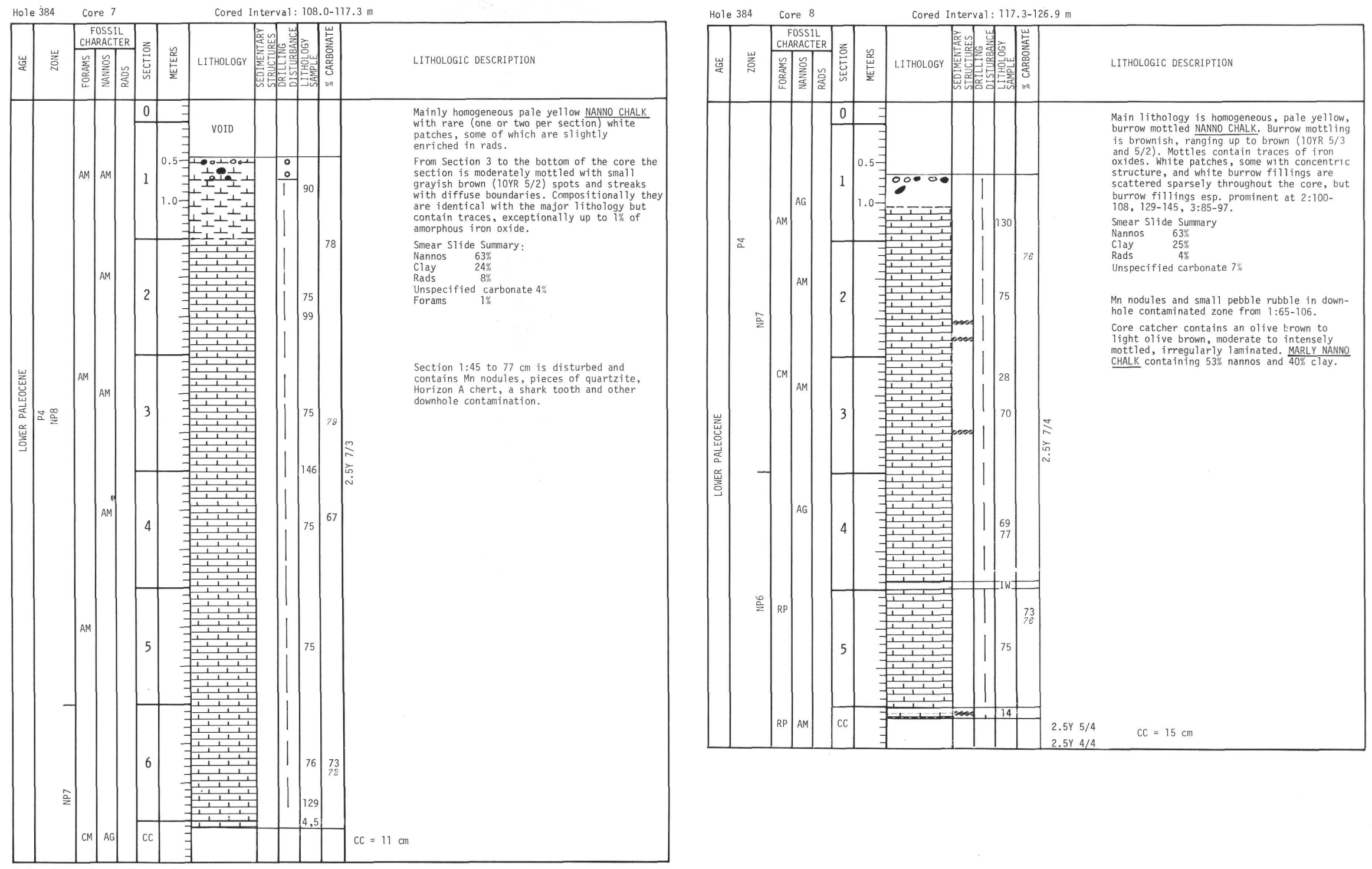

Explanatory notes in Chapter 1 

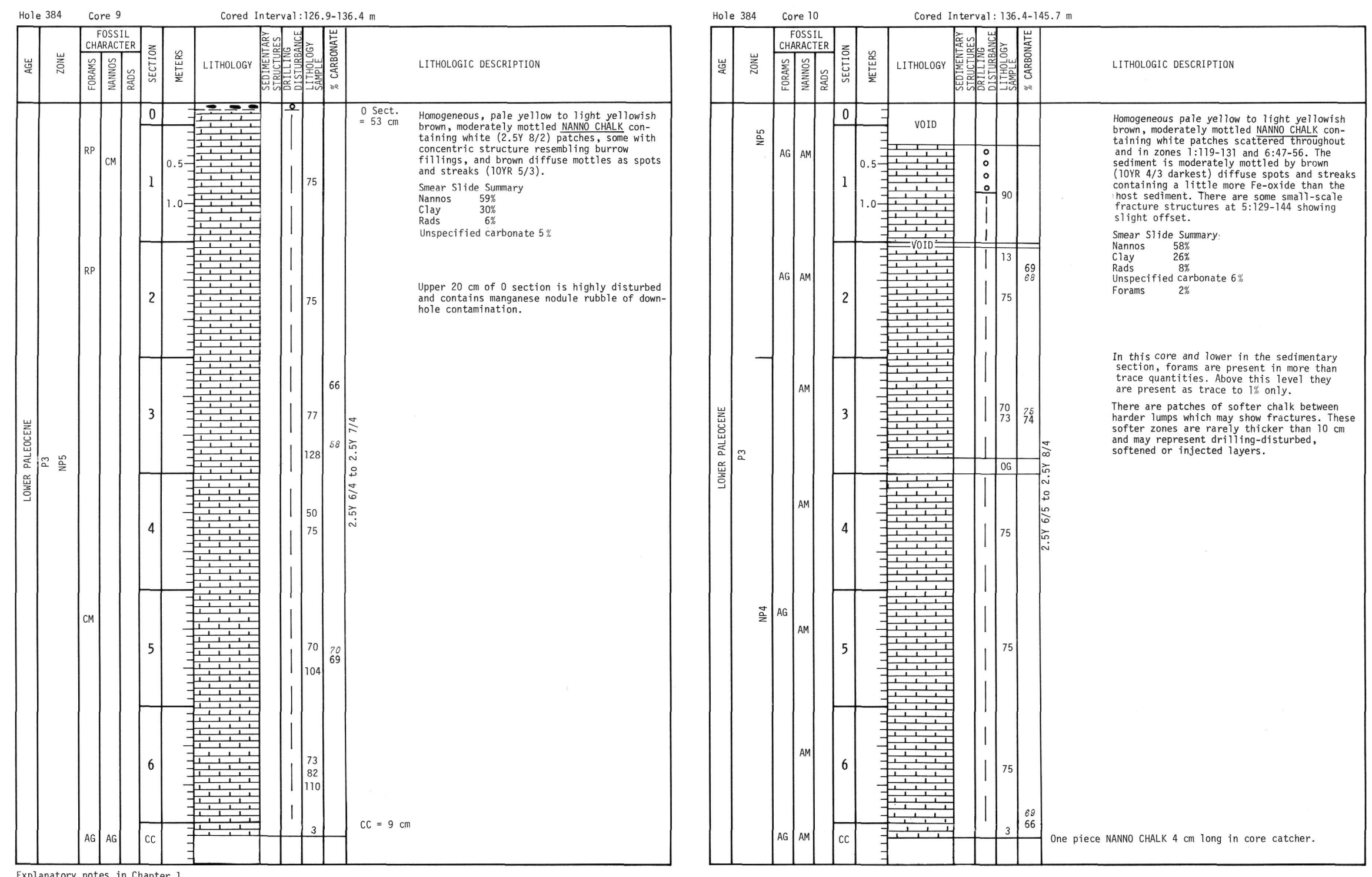

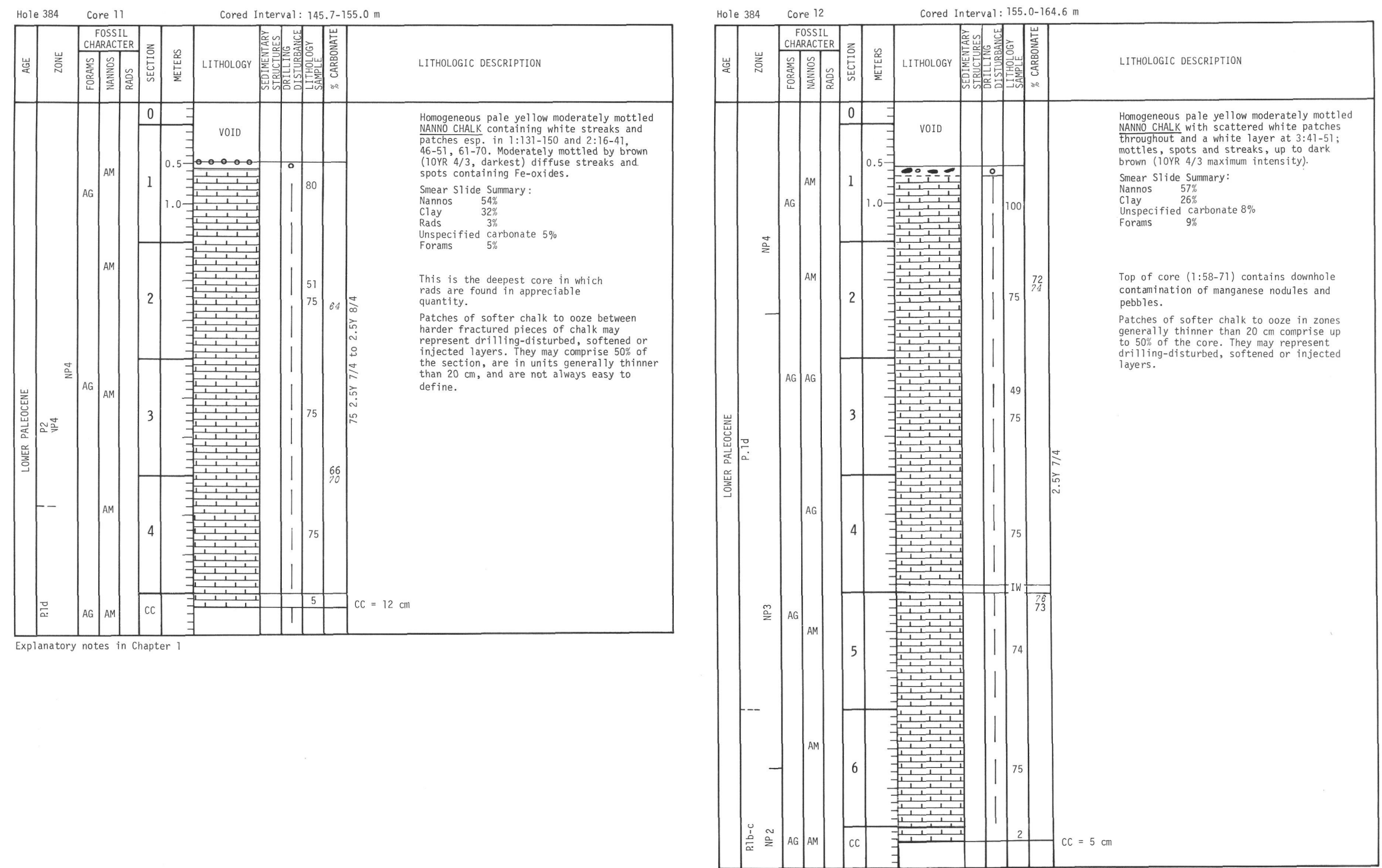

Homogeneous pale yel low moderately mottled
NABNo cHALK containing white streaks and 46-57, 61-70, Moderately mott led by brow This is the deepest core in which a lavers. They may comprise $50 \%$ of section, are in units generally thi 

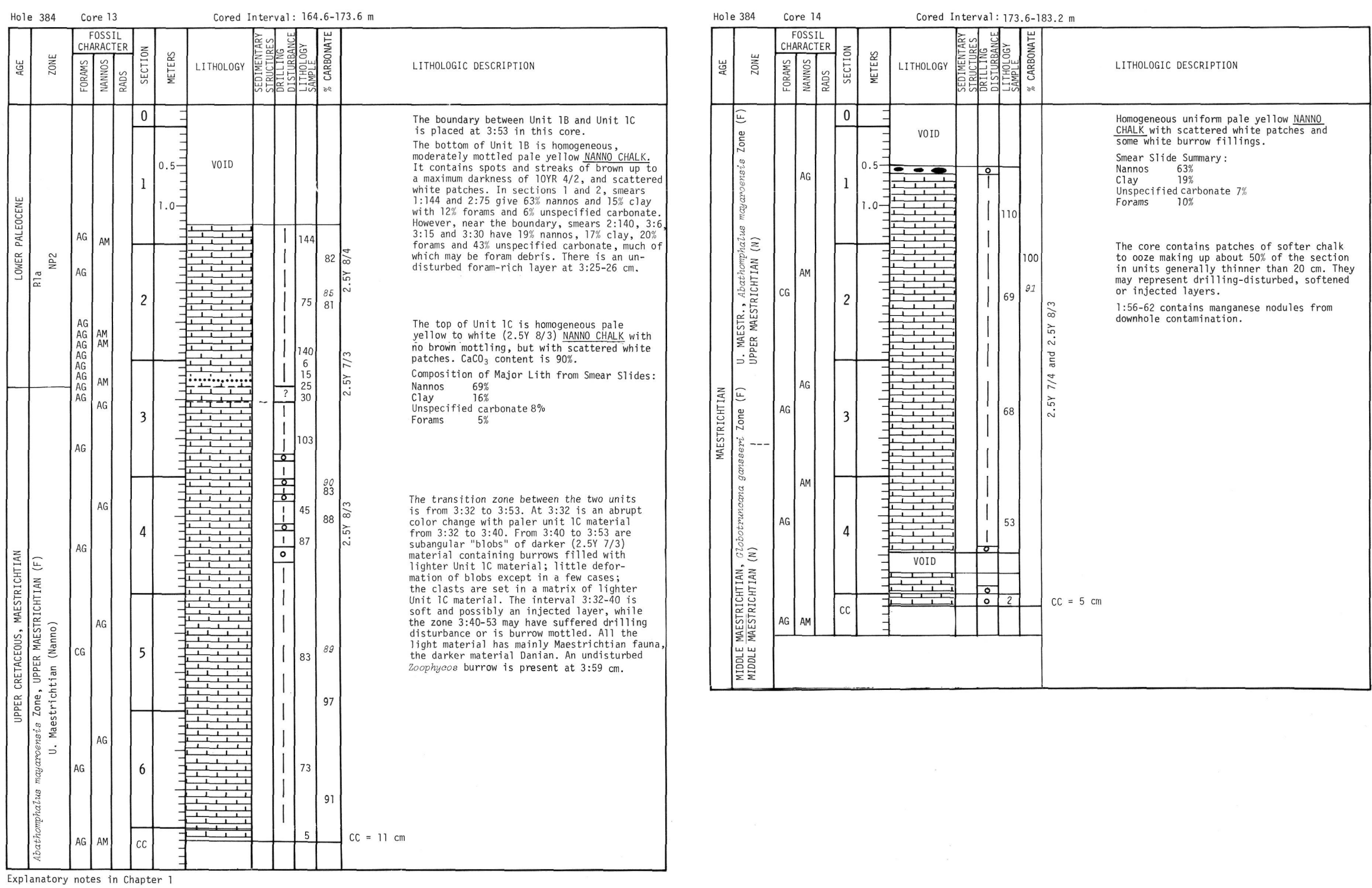

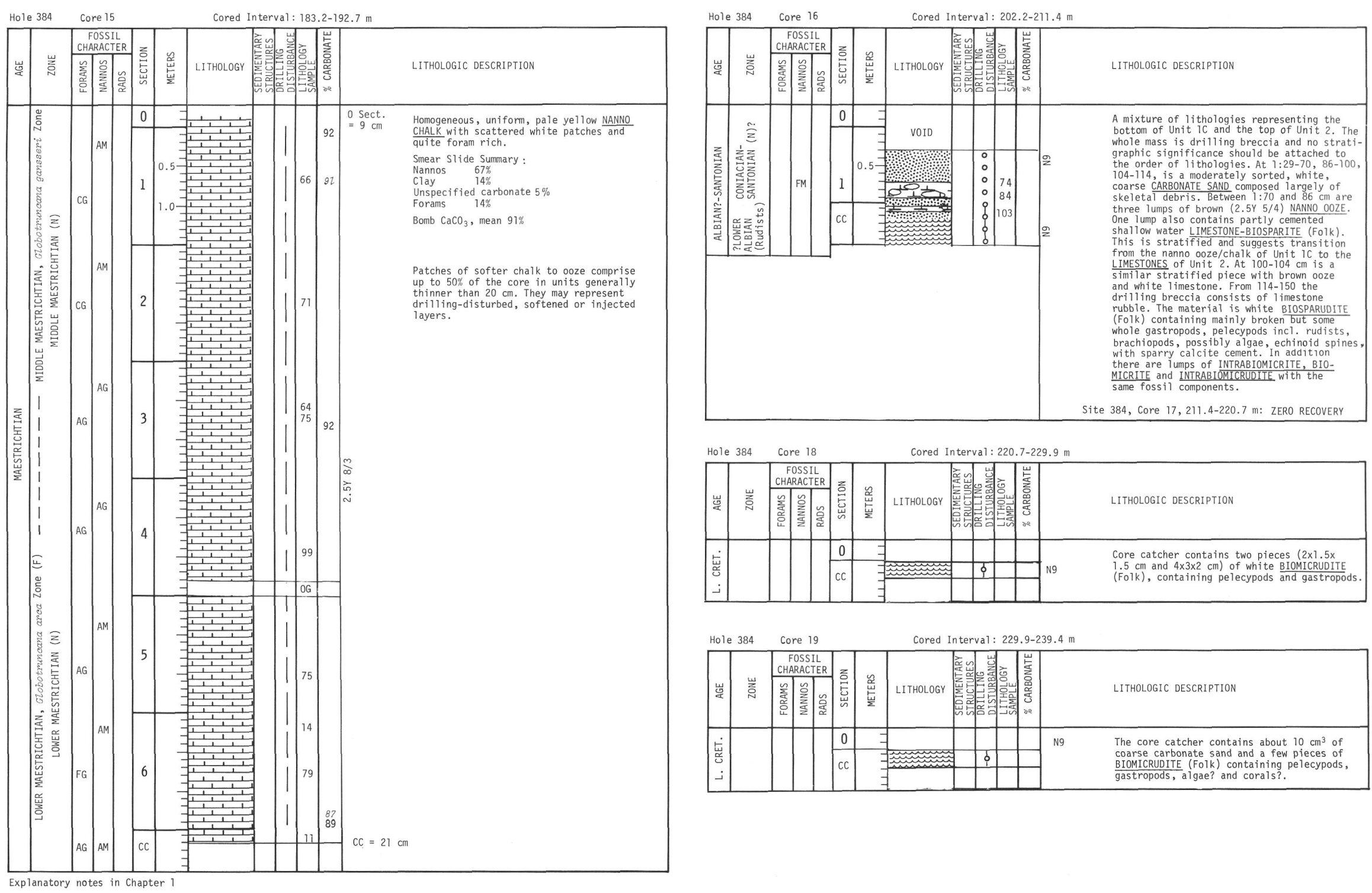

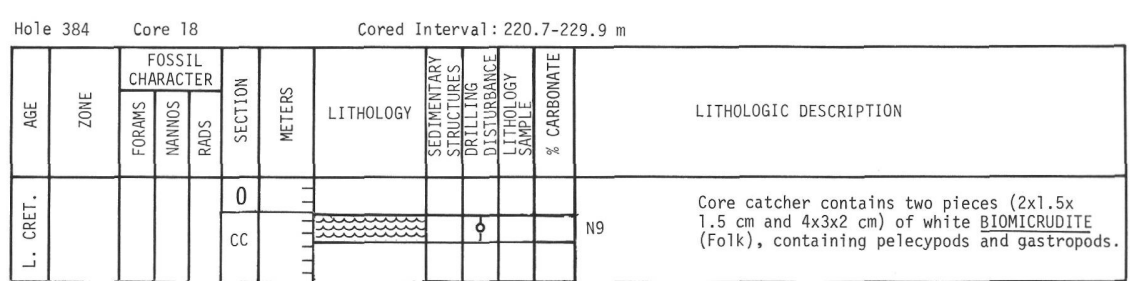

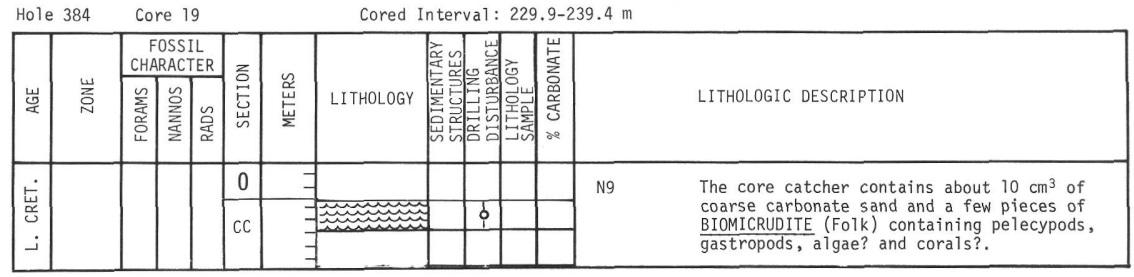



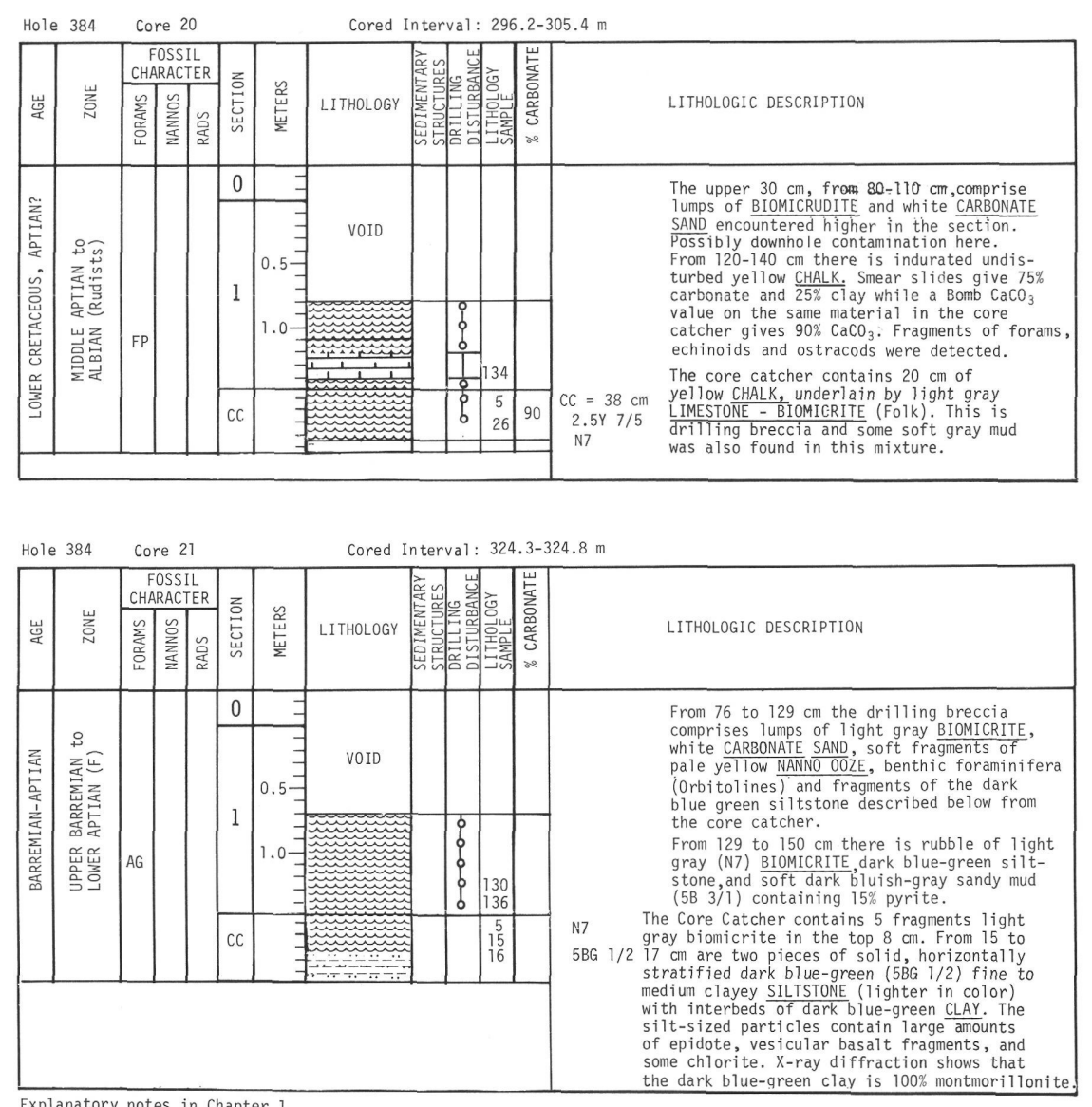


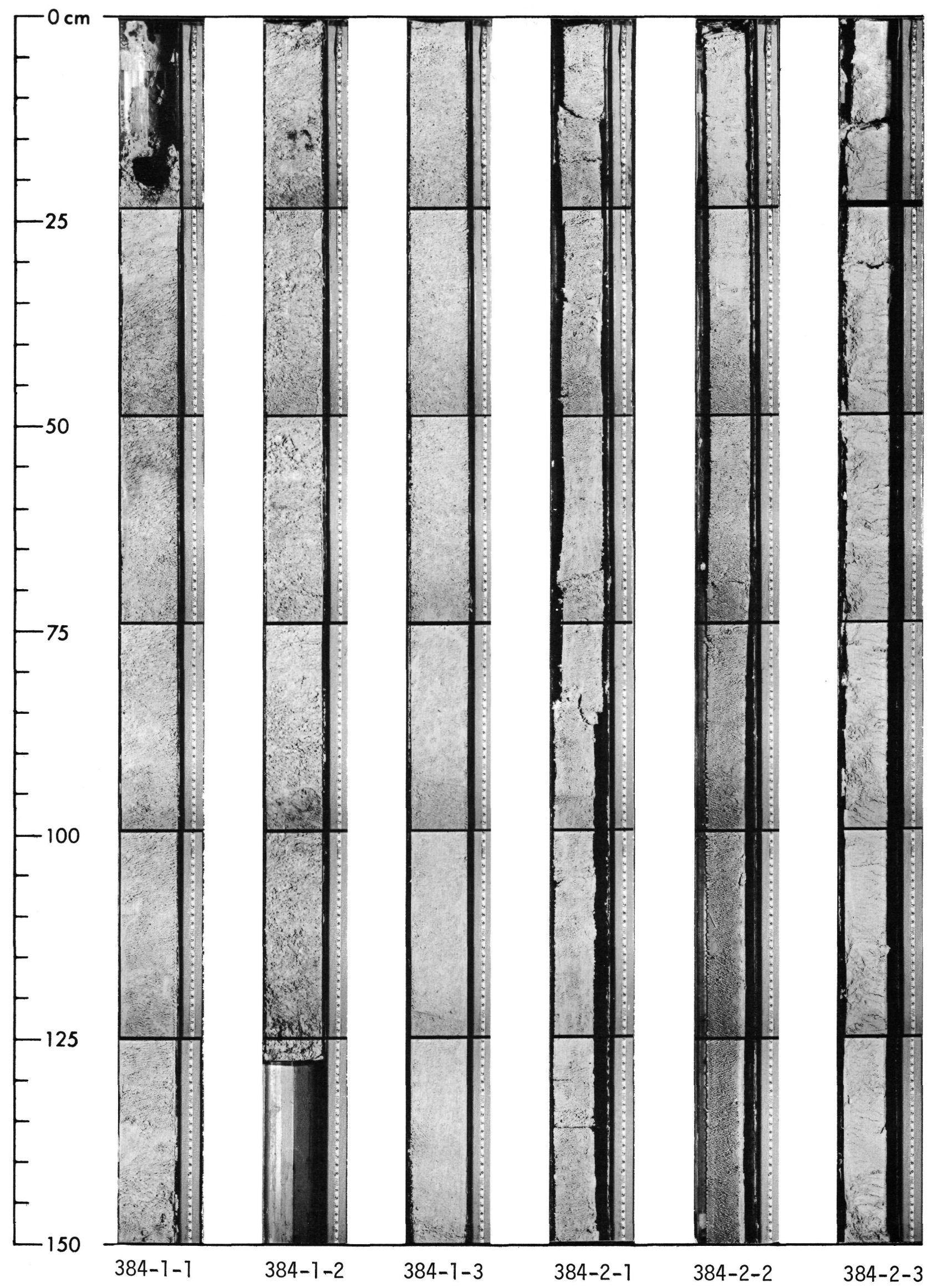




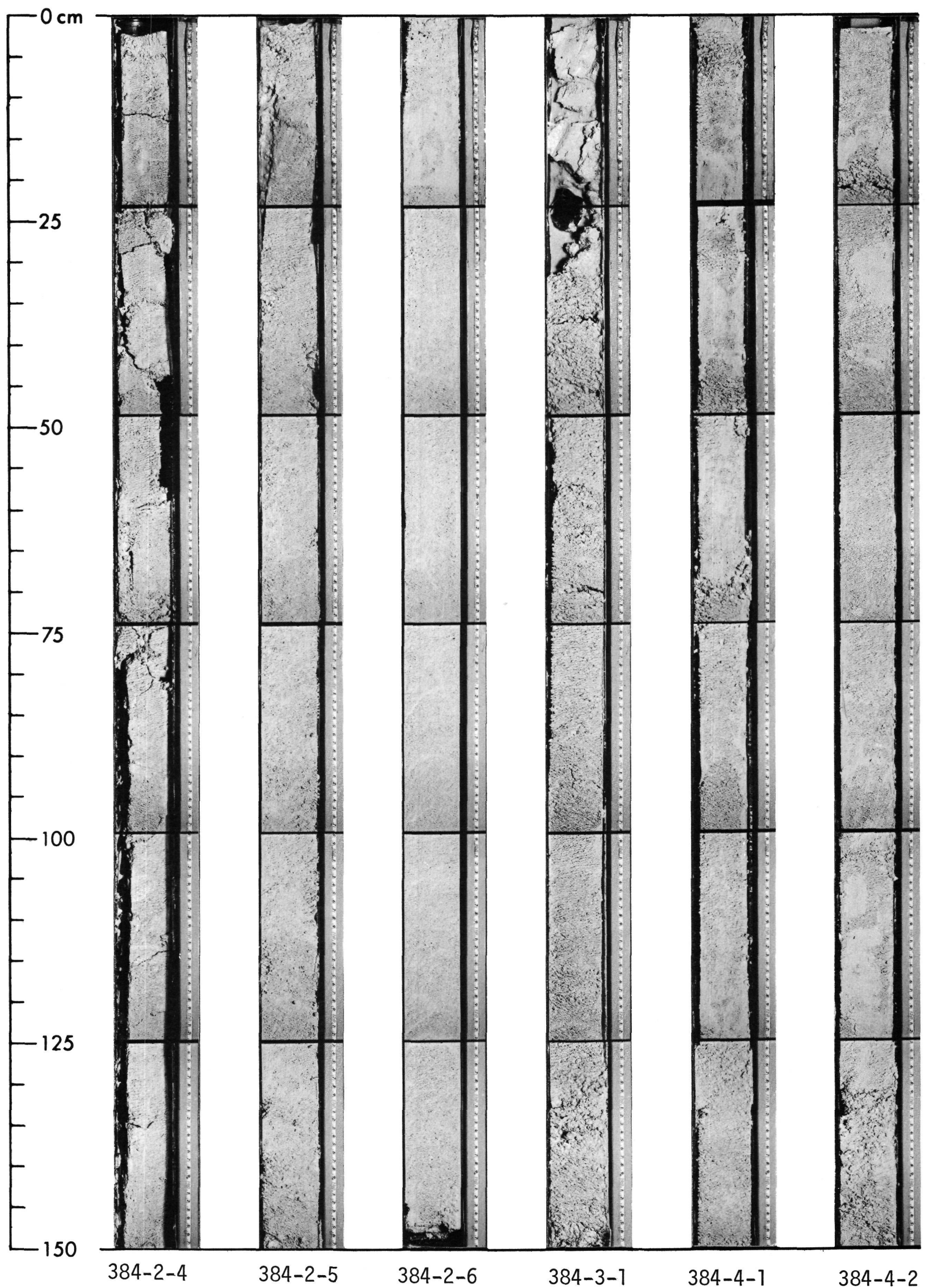




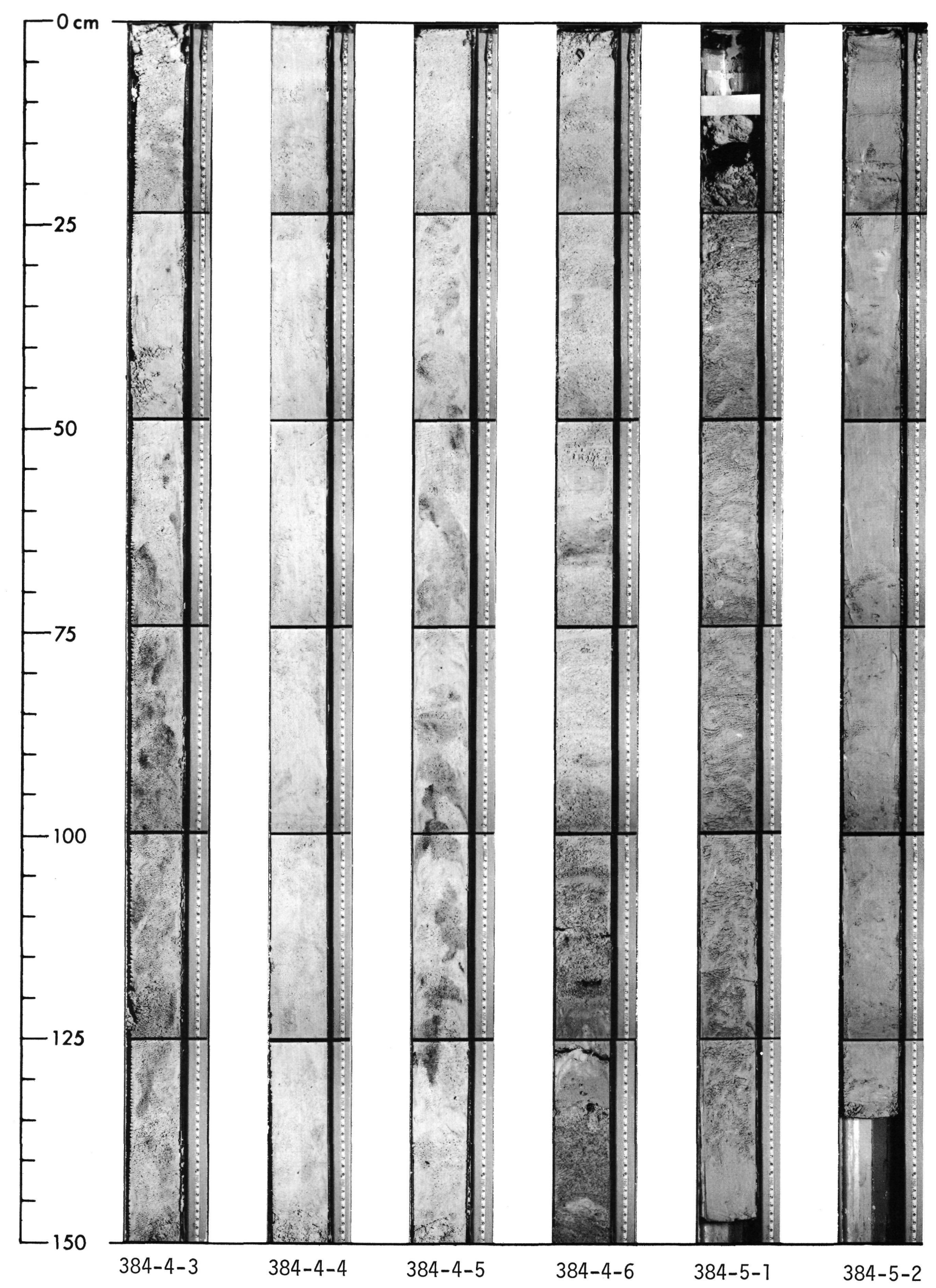




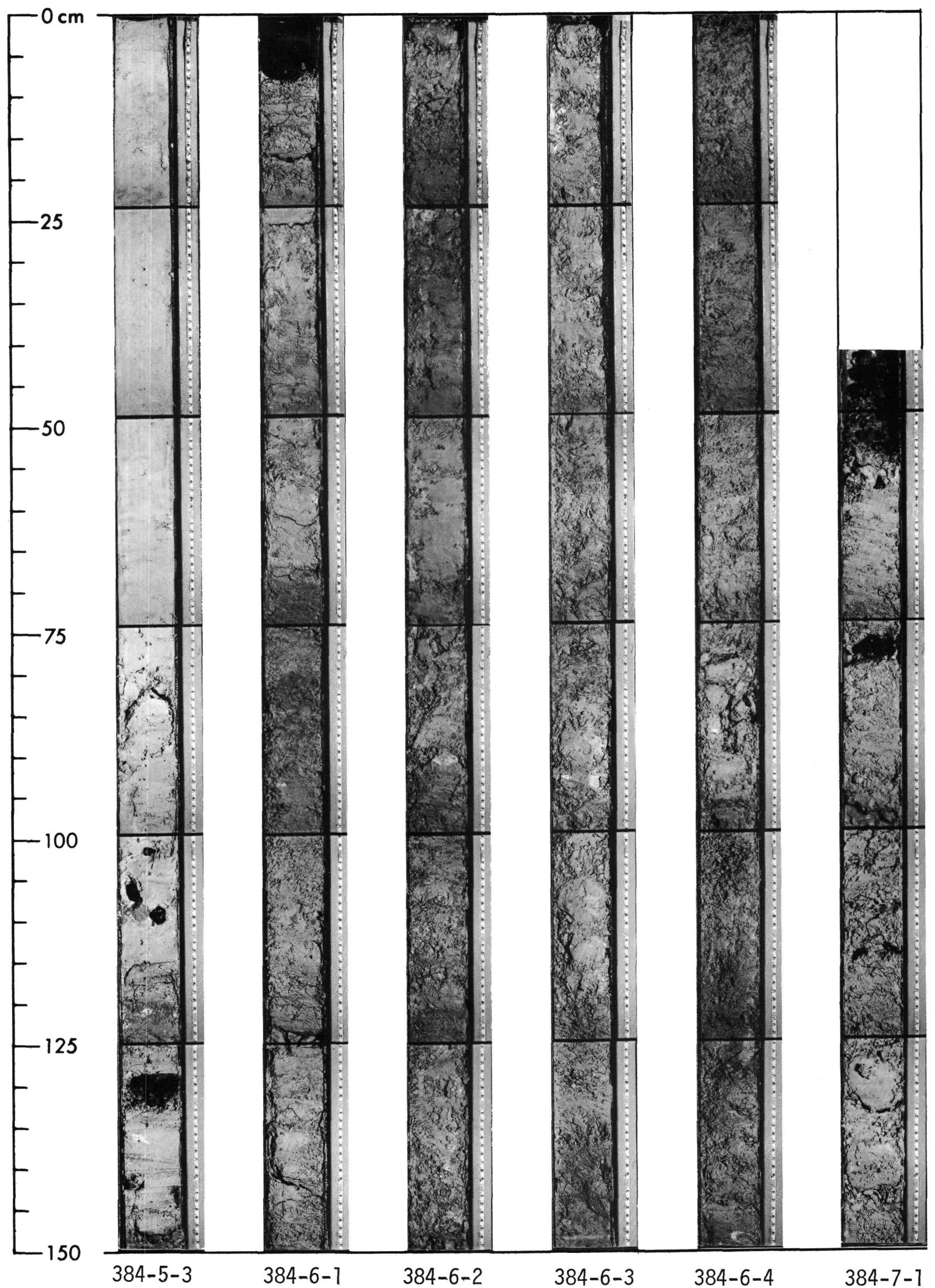




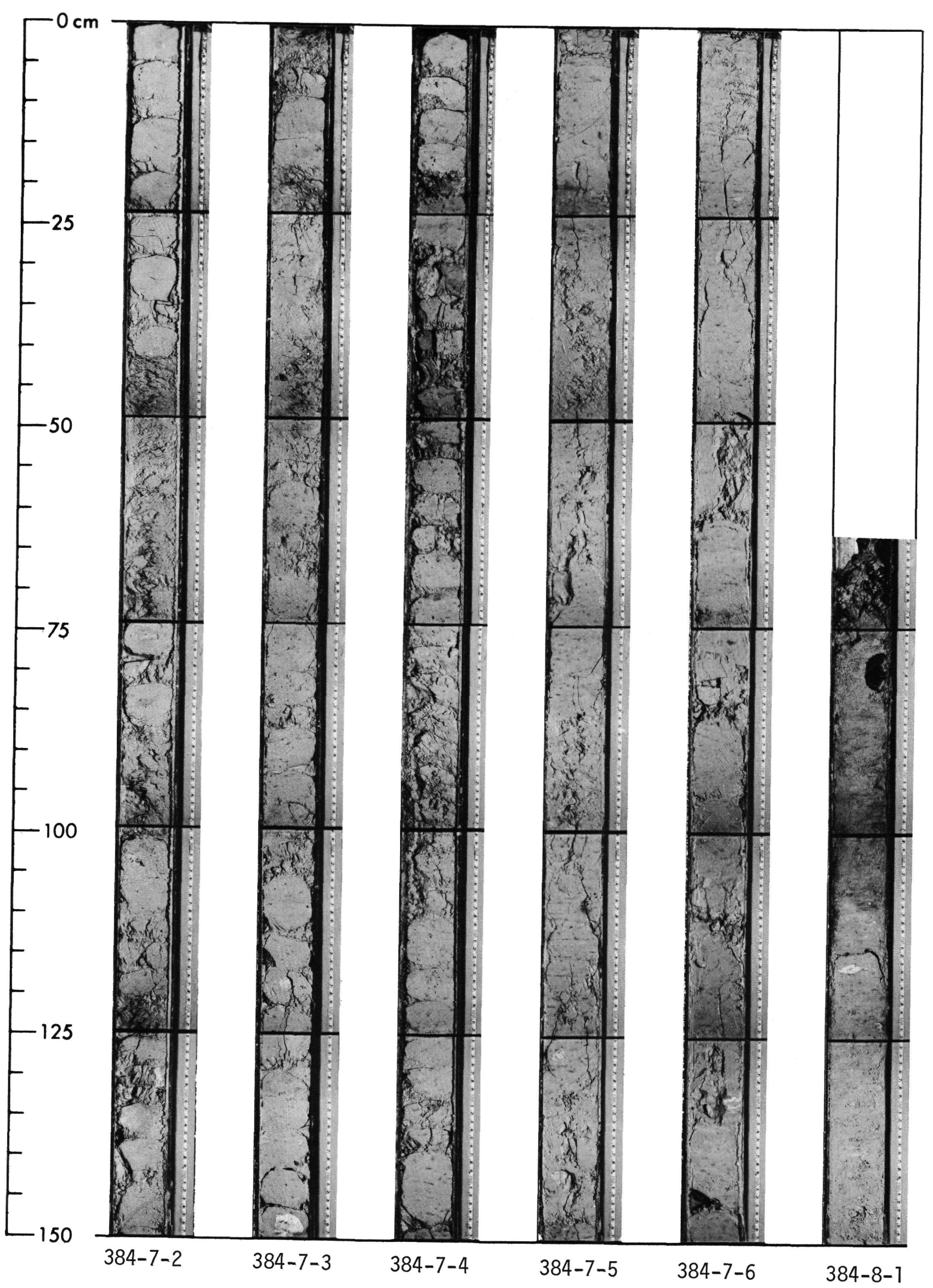




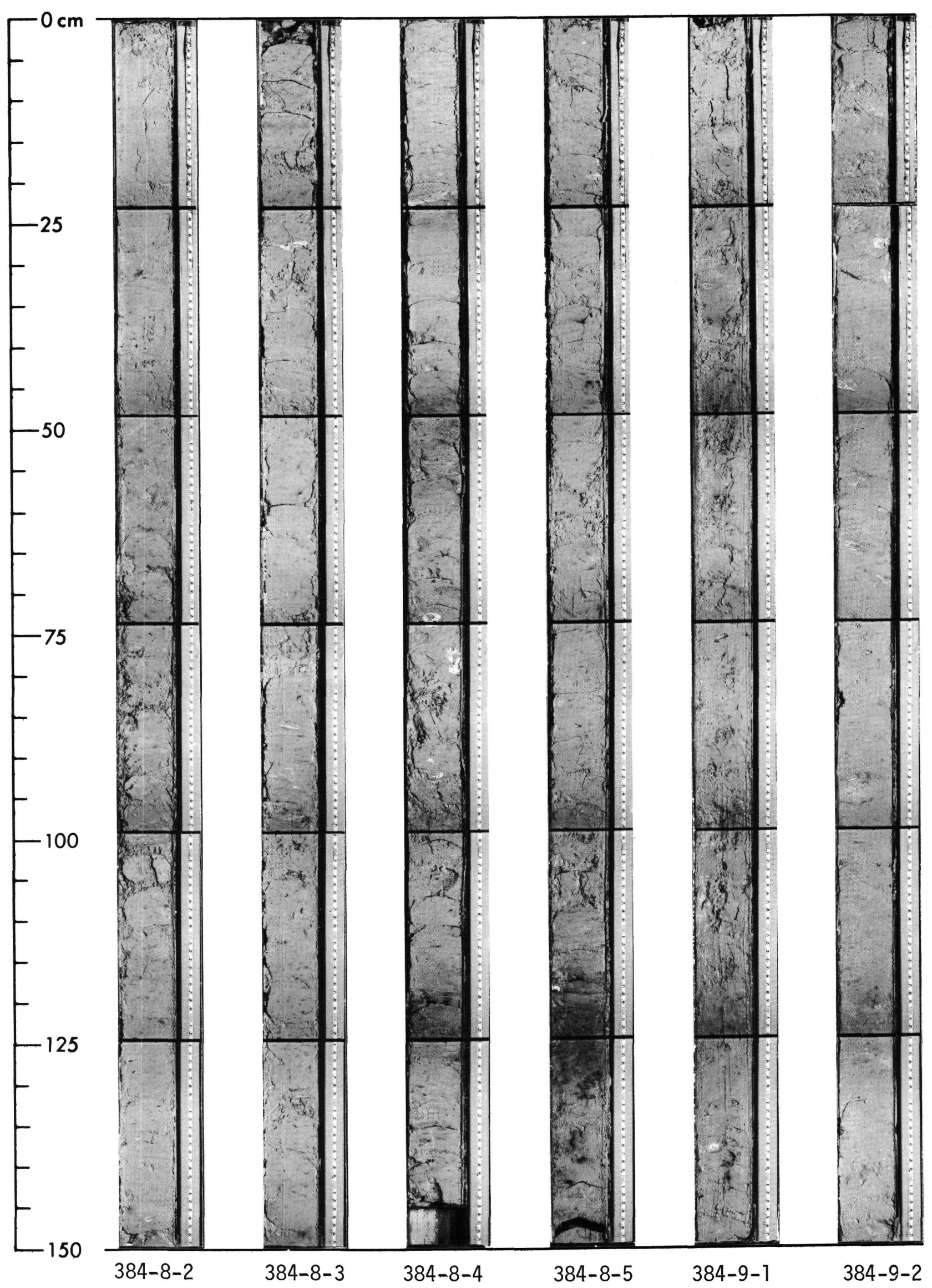




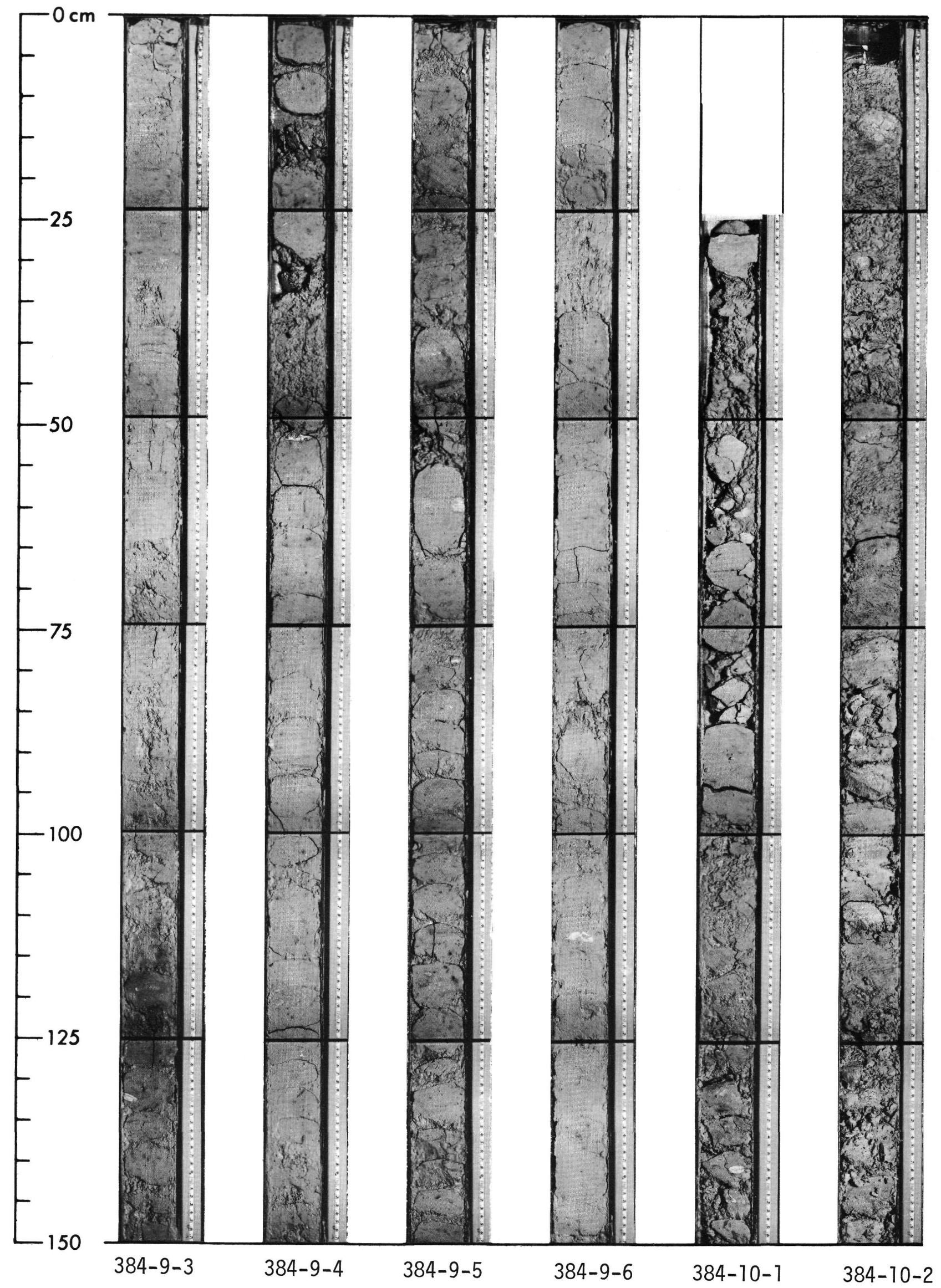




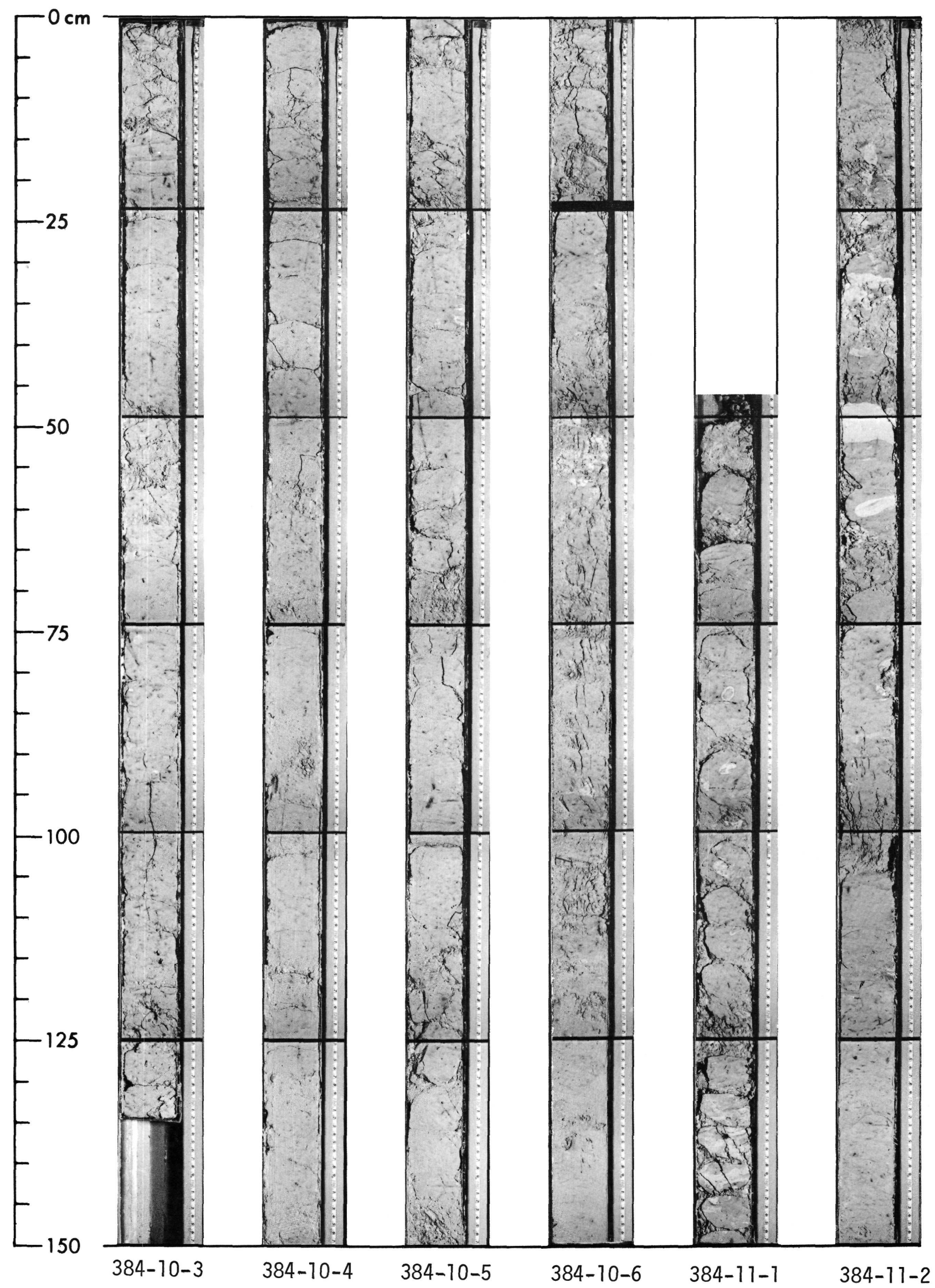




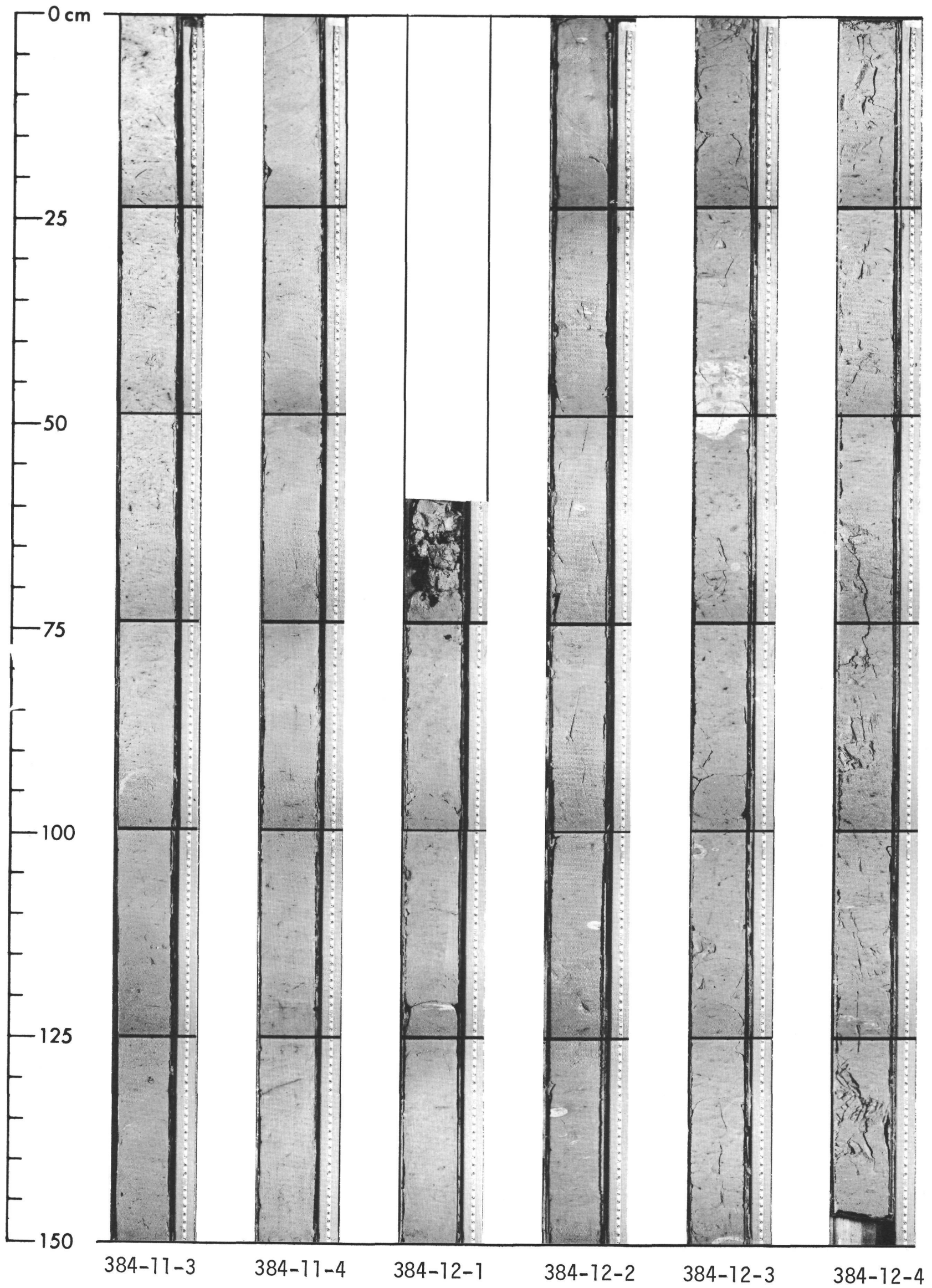




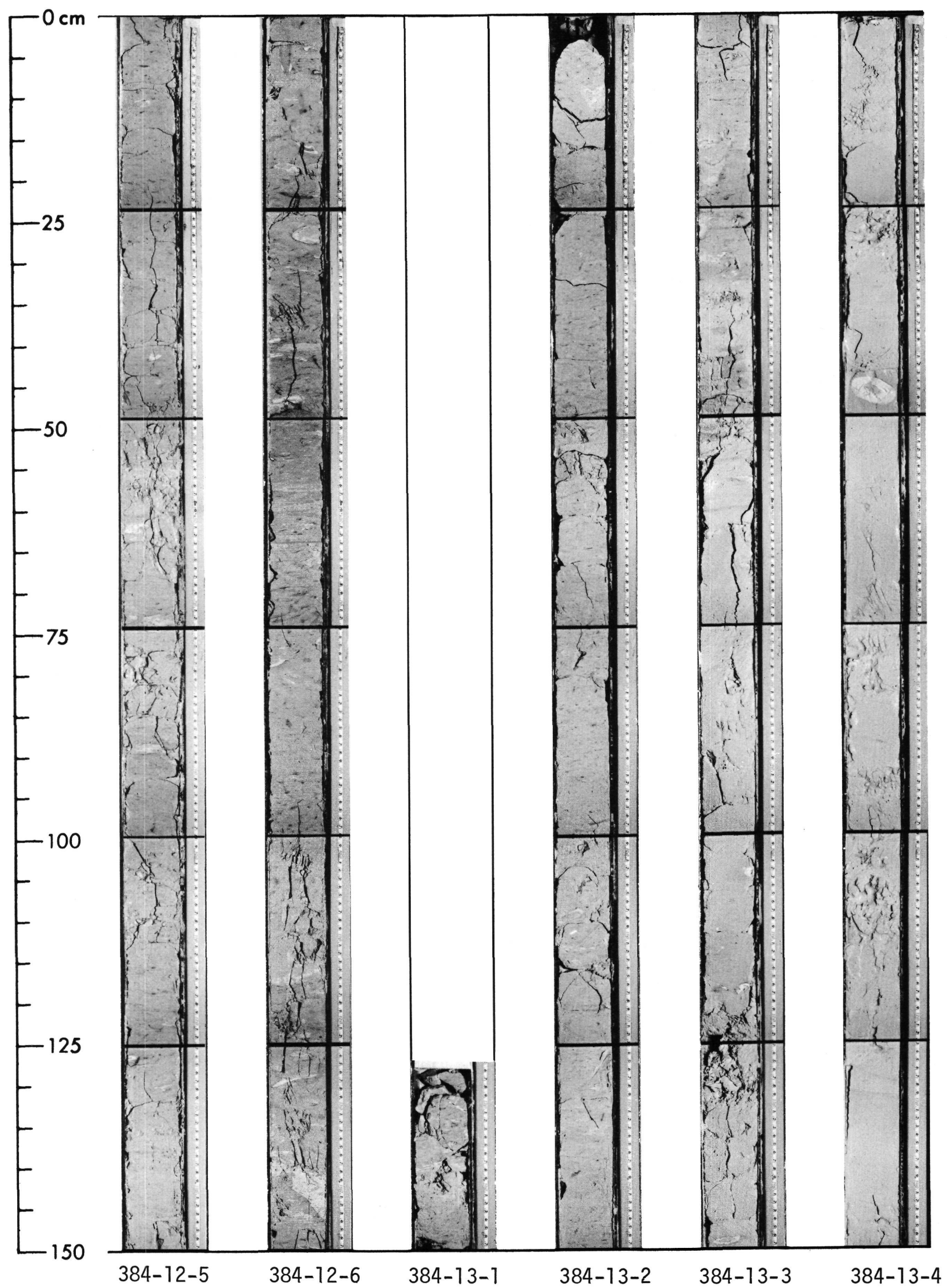




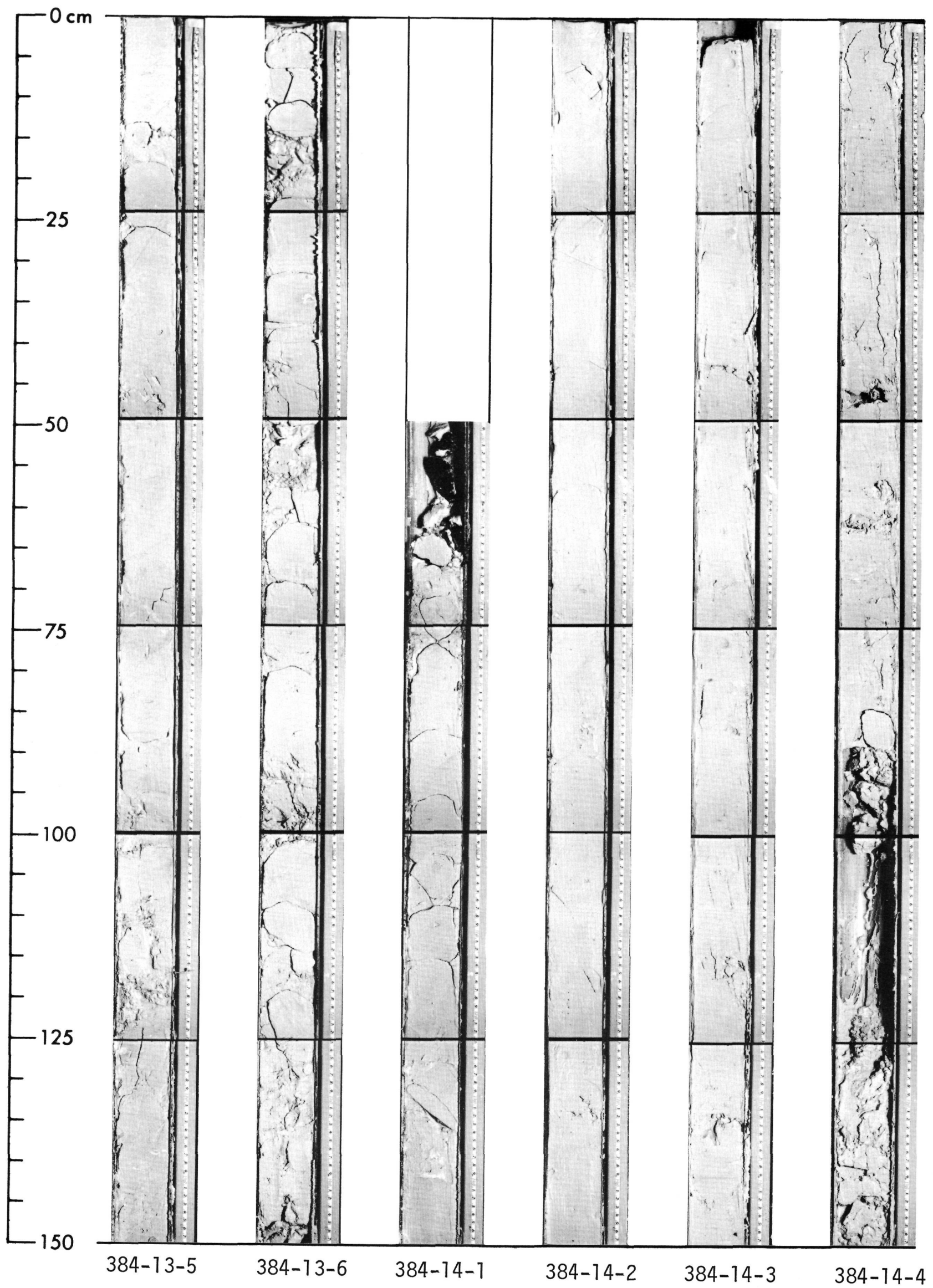




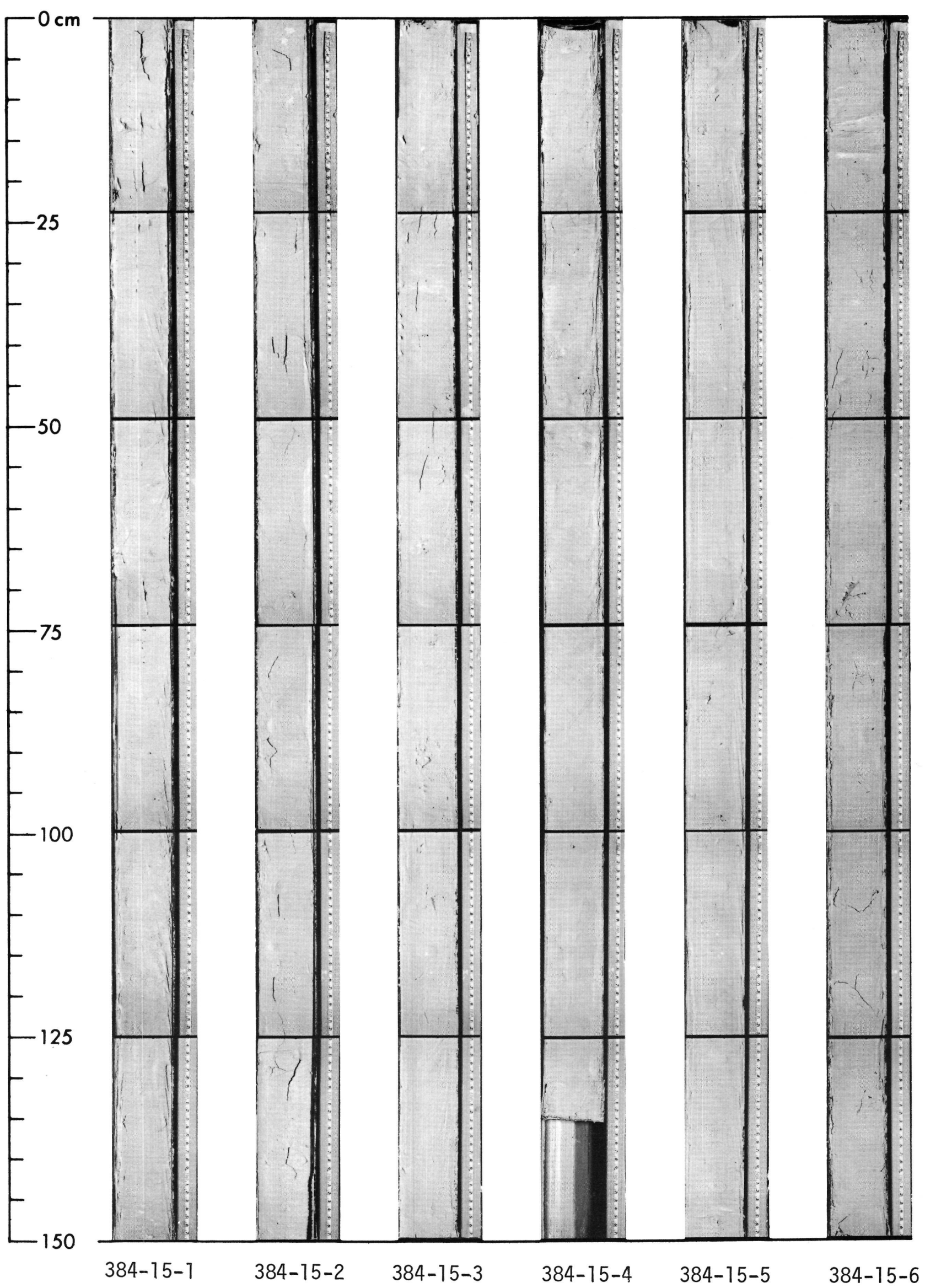




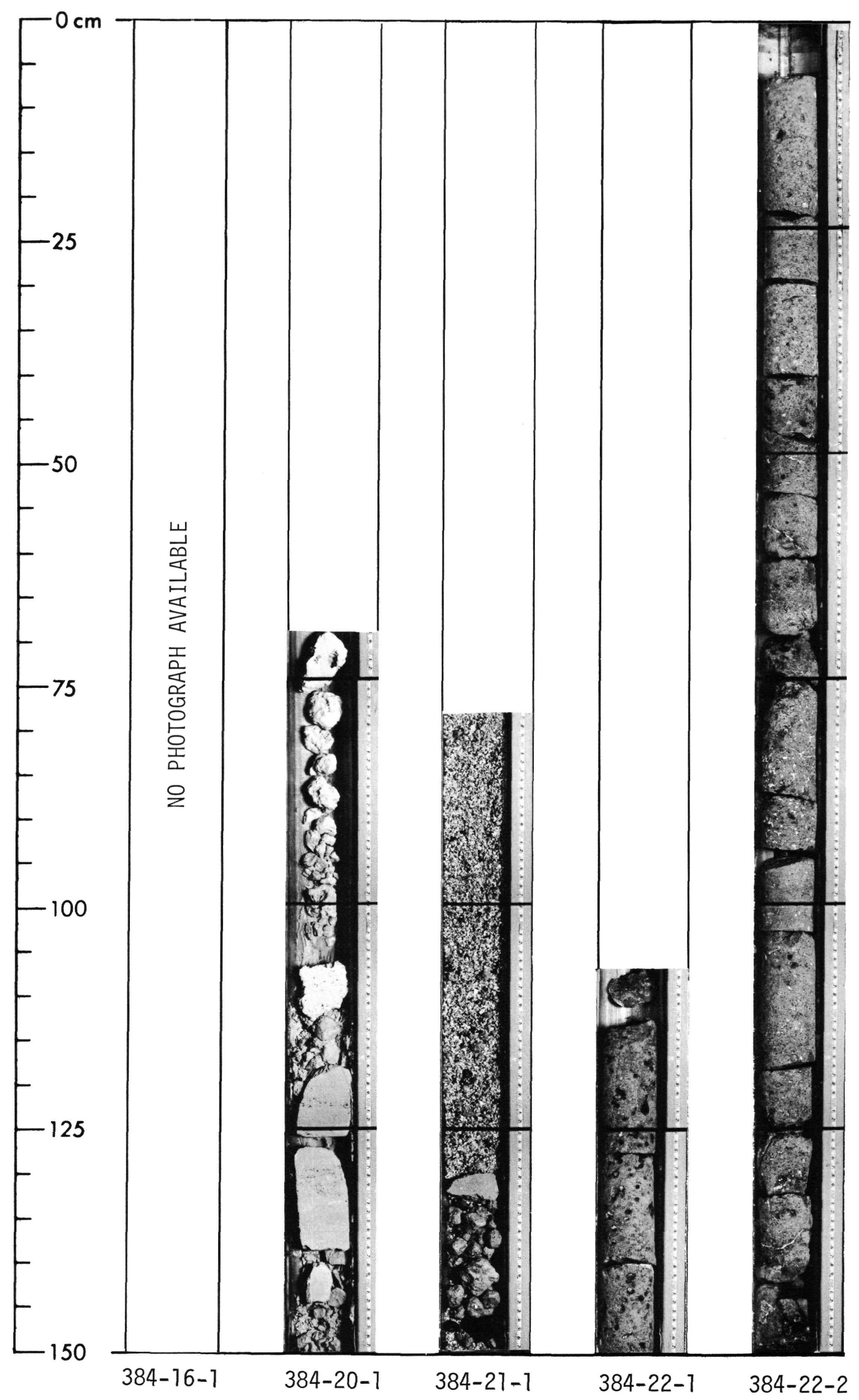

